OPEN ACCESS

Edited by:

Agnieszka Paradowska-Gorycka,

Rheumatology and Rehabilitation,

Poland

Reviewed by:

Chiara D'Angelo,

University of Studies G. d'Annunzio

Chieti and Pescara, Italy

Takeshi Fujii,

Doshisha Women's College of Liberal

Arts, Japan

${ }^{*}$ Correspondence:

Girdhari Lal

glal@nccs.res.in

Specialty section:

This article was submitted to

Autoimmune and

Autoinflammatory Disorders,

a section of the journal

Frontiers in Immunology

Received: 29 January 2021

Accepted: 26 March 2021

Published: 15 April 2021

Citation:

Halder N and Lal G

(2021) Cholinergic System and

Its Therapeutic Importance in Inflammation and Autoimmunity.

Front. Immunol. 12:660342. doi: 10.3389/fimmu.2021.660342

\section{Cholinergic System and Its Therapeutic Importance in Inflammation and Autoimmunity}

\author{
Namrita Halder and Girdhari Lal * \\ Laboratory of Autoimmunity and Tolerance, National Centre for Cell Science, Ganeshkhind, Pune, India
}

Neurological and immunological signals constitute an extensive regulatory network in our body that maintains physiology and homeostasis. The cholinergic system plays a significant role in neuroimmune communication, transmitting information regarding the peripheral immune status to the central nervous system (CNS) and vice versa. The cholinergic system includes the neurotransmitter $\backslash$ molecule, acetylcholine (ACh), cholinergic receptors (AChRs), choline acetyltransferase (ChAT) enzyme, and acetylcholinesterase (AChE) enzyme. These molecules are involved in regulating immune response and playing a crucial role in maintaining homeostasis. Most innate and adaptive immune cells respond to neuronal inputs by releasing or expressing these molecules on their surfaces. Dysregulation of this neuroimmune communication may lead to several inflammatory and autoimmune diseases. Several agonists, antagonists, and inhibitors have been developed to target the cholinergic system to control inflammation in different tissues. This review discusses how various molecules of the neuronal and nonneuronal cholinergic system (NNCS) interact with the immune cells. What are the agonists and antagonists that alter the cholinergic system, and how are these molecules modulate inflammation and immunity. Understanding the various functions of pharmacological molecules could help in designing better strategies to control inflammation and autoimmunity.

Keywords: choline acetyltransferase (ChAT), cholinergic system (CS), muscarinic acetylcholine receptors (mAChR), neuroimmunology, neurotransmitters, nicotinic acetylcholine receptors (nAChR)

\section{INTRODUCTION}

The complex bi-directional neuroimmune communication maintains each organ's physiological balance and functions in the body. The central and peripheral neuronal circuits, immune cells and cytokines, neuro-endocrine hormonal systems, gut microbiota and their metabolites, and the bloodbrain and intestinal mucosal barriers are important players throughout this regulatory network. Any disturbance in these systems alters the delicate balance between health and disease (1). 
The physiological mechanism of cross-talk within the neural network and reticuloendothelial system that regulates immune response, metabolism, and a vast array of pivotal functions constitute the inflammatory reflex (IR). The parasympathetic afferent and efferent arms of the Vagus nerve (VN) serve as a control center that connects impulses between the brain and internal organs (2). The afferent fibers of the VN have innervation in the reticuloendothelial system and major organs of the body. It is activated by low cytokines or endotoxins present in the tissues and communicates via neuronal signals sent to the poor cytokine milieu of the central nervous system (CNS) (3).

ACh has also been detected in cells of non-neural origins and microbes. It is vastly found in cardiomyocytes, the entire gastrointestinal (GI) tract, bladder urothelial cells, and various human leukemic cells, demonstrating its diverse function within an organism. The non-neuronal cholinergic system (NNCS) is made up of neurotransmitter acetylcholine, its synthesizing and degrading enzymes, transporters, and receptors within epithelial cells in airways, intestine, skin, urothelium, vagina, placenta, cornea, granulosa cells, endothelial cells, immune cells and mesenchymal cells (4). Signal transduction in keratinocytes, lymphocyte proliferation and differentiation, regulation of cytoskeleton of epithelial cells, differentiation and migration of cells in the epidermis for wound healing, ciliary activities, and regulation of the permeability in the epithelial lining of airways in an autocrine/paracrine manner (5). The details of neuronal origin cholinergic systems, their components, and signaling in the tissues have been discussed earlier $(6,7)$.

In this review, several immune cells that express components of NNCS and respond to neurotransmitters, specific agonists, and antagonists and their contribution to inflammation and autoimmunity are discussed. We further explored the different cholinergic agonists, antagonists, and AChE inhibitors (AChEI) that modulate the immune system and their effect on the differentiation and function of various immune cells.

\footnotetext{
Abbreviations: $\alpha$-BTX, $\alpha$-bungarotoxin; ACh, Acetylcholine; AChE, AcetylcholinesteraseAChEI, Acetylcholinesterase inhibitor; AChRs, Acetylcholine receptor; AD, Alzheimer Disease; BBB, Blood-Brain Barrier; BChE, Butyrylcholinesterase; BChEI, Butyrylcholinesterase inhibitor; cAMP, Cyclase adenosine monophosphate; $\mathrm{CD}$, Crohn's disease; ChAT, Choline acetyltransferase; $\mathrm{ChE}$, cholinesterase; ChEI, cholinesterase inhibitor; ChT, Choline transporter; CIA, Collagen-induced arthritis; CNS, Central nervous system; COPD, Chronic obstructive pulmonary disease; CS, Cholinergic status; CTL1, Choline transporter-like protein 1; CTLA-4, Cytotoxic T lymphocyteassociated protein 4; EAE, Experimental autoimmune encephalomyelitis; ENS, Enteric nervous system; FOXP3: Forkhead box P3; GI, Gastrointestinal; GPCRs, G protein-coupled receptors; HPA, Hypothalamic-pituitary-adrenal axis; IBD, Inflammatory bowel disease; IBS, Irritable bowel syndrome; ILs, Interleukins; JAK-STAT, Janus kinases signal transducer and activator of transcription; LTB-4, Leukotriene B4; MAPK, Mitogen-activated protein kinase; mAChRs, Muscarinic acetylcholine receptor; MG, Myasthenia Gravis; MS, Multiple sclerosis; nAChRs, Nicotinic acetylcholine receptor; NICUs, neuro-immune cell units; NK cells, Natural killer cells; NMJ, Neuromuscular junction; NNCS, Non-neuronal cholinergic system; NO, nitric oxide; OXO-M, Oxotremorine; PBMCs, Peripheral blood mononuclear cells; PHA, phytohemagglutinin; PKC, protein kinase C; PLC, Phospholipase C; RA, Rheumatoid arthritis; SLE, Systemic lupus erythematosus; VAChT; Vesicular acetylcholine transporter; VN, Vagus nerve; VNS, Vagus nerve stimulation; WT, wild-type.
}

\section{COMPONENTS OF THE NON-NEURONAL CHOLINERGIC SYSTEM (NNCS) IN IMMUNITY}

\section{Acetylcholine (ACh)}

The cholinergic system, which is found in both neuronal and non-neuronal cells, forms a network that performs various complex functions in the body. The ChAT enzyme synthesizes $\mathrm{ACh}$ from the precursor molecules, choline (8). The majority of choline is formed by the degradation of lipid, especially lecithin, and hydrolysis of acetylcholine (9). Acetyl-coenzyme A (AcetylCoA), produced by mitochondria, is used for the esterification of choline by the cytoplasmic enzyme ChAT in the parasympathetic nervous system and motor neurons (Figure 1). In addition to the $\mathrm{VN}, \mathrm{T}$ cells, B cells, dendritic cells (DCs), and macrophages in the follicular and marginal zones of the spleen are other major sources of ACh (10). Immune cells have the machinery to synthesize $\mathrm{ACh}$ and directly release it into the bloodstream. In contrast, neuronal cells store ACh after synthesis in a specialized neurosecretory vesicle and release it via exocytosis at specialized synaptic clefts (11).

The relative concentration of $\mathrm{ACh}$ in humans is found to be $8.66 \pm 1.02 \mathrm{pmol} / \mathrm{ml}$ in the blood and $3.12 \pm 0.36 \mathrm{pmol} / \mathrm{ml}$ in plasma (12). Ach is also produced by gut microbes like Lactobacillus plantarum (13). Physiological levels of ACh present in the bloodstream affect immune cells in the lymphoid tissues and those that are migrating to the site of inflammation in an autocrine and paracrine manner. Recent studies have correlated lower levels of $\mathrm{ACh}$ in chronic inflammatory neurodegenerative diseases like Alzheimer's disease (AD), vascular dementia (VD), and multiple sclerosis (MS) (14-16). The elevated ACh level is also linked to inflammatory diseases like atopic dermatitis, chronic obstructive pulmonary disease (COPD), and periodontal disease (17-19). Patients with acute ischemic stroke had higher levels of lymphocyte-derived-ACh, which was linked to an increase in post-stroke infection and mortality (20). The diverse ways in which ACh binds to and activates different types of receptors on the surface of various cells and tissues explain its differential outcome and functions within an organism.

\section{Choline Acetyltransferase (ChAT) Enzyme}

ChAT is responsible for the biosynthesis of ACh. The ACh content in cells is proportional to the expression of ChAT within the cells (21). This enzyme is synthesized in the perikaryon of cholinergic neurons and is under the control of multiple regulatory elements (22). The enzyme occurs in both soluble and membrane-bound forms and is transcribed from various ChAT mRNA species that share identical coding regions but differ in the 5'-noncoding regions (23). R, N0, N1, N2, and Mtypes are some of the ChAT mRNA species that have been identified (24). N1 and N2 type mRNA transcript of ChAT is expressed by $\mathrm{T}$ cells, thus differing from the R type in CNS (25). In a murine model, ChAT mRNA is constitutively expressed in T 


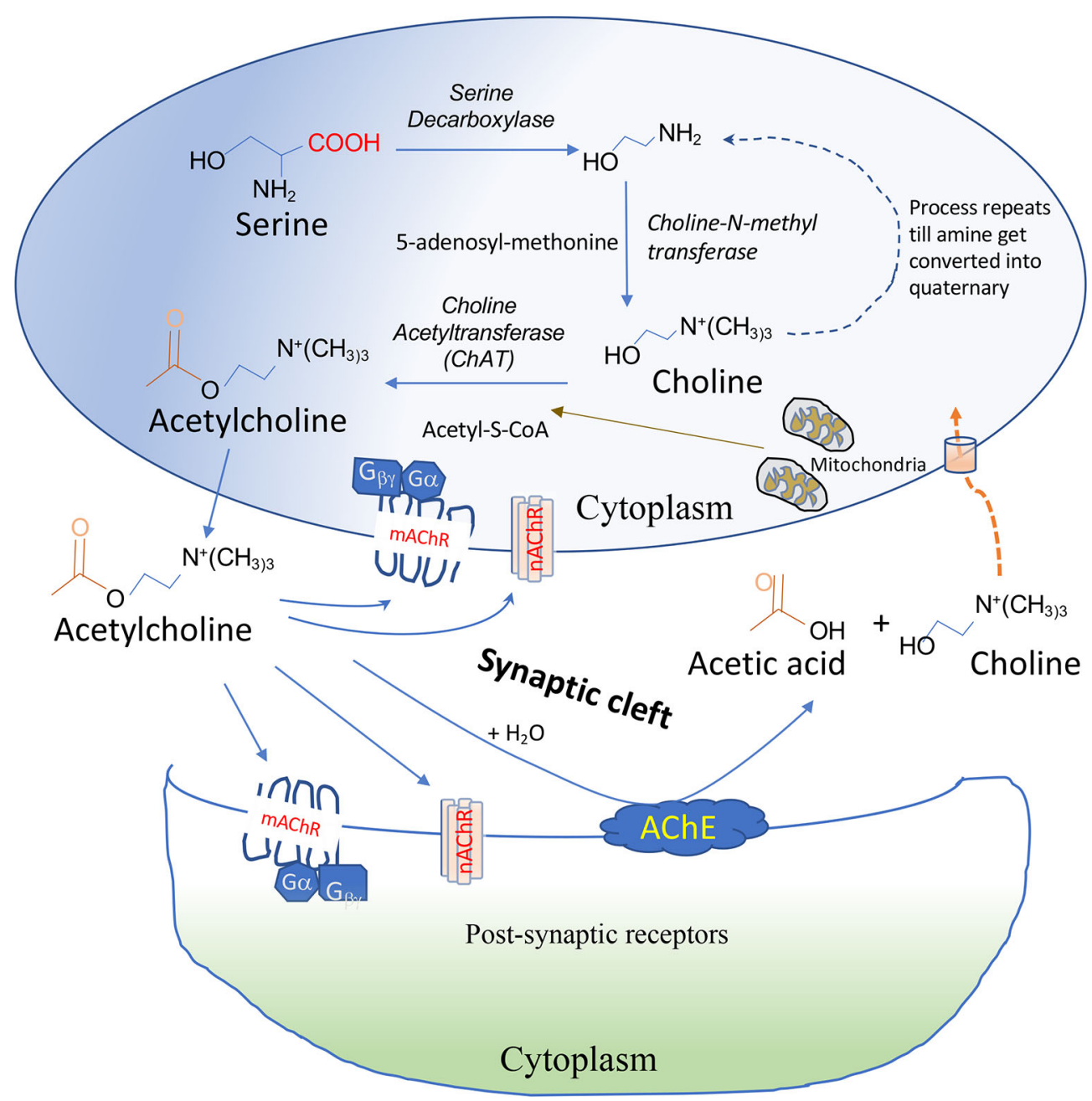

FIGURE 1 | Synthesis and degradation of ACh. ACh is synthesized from Acetyl-S-CoA and choline by the choline acetyltransferase (ChAT) enzyme in the cytoplasm. ACh is secreted out immediately after synthesis in non-immune cells but stored in a specialized vesicle in neuronal cells secreted at presynaptic neurons after activation. Release of ACh requires an influx of Ca2+ ion in the cells followed by docking of ACh-containing vesicle docking at membrane and fusion and release of neurotransmitter into the synaptic cleft via a process known as exocytosis. ACh binds via the autocrine or paracrine mechanism to nicotinic acetylcholine receptors (nAChRs) or muscarinic acetylcholine receptors (mAChRs) on post-synaptic neurons or immune cells. Acetylcholinesterase (AChE) present on the membrane can degrade ACh into choline and acetic acid. Extracellular choline formed is transported into the cells by choline transporters.

and B cells and mononuclear lymphocytes isolated from the renal vasculature (21). Upon immunological activation, peritoneal macrophages and bone marrow-derived DCs increase ChAT transcription compared to cells in the resting stages (26). ChAT mRNA expression is also detected in human leukemic $\mathrm{T}$ cell lines, human peripheral blood T cell and B cells, human lung and alveolar macrophages, and monocytes (27-29). COPD patients' neutrophils were observed to have overexpression of ChAT. In contrast, epithelial cells of ulcerative colitis patients displayed downregulation of ChAT, indicating, ChAT has differential involvement in different diseases affecting epithelial linings and smooth muscles $(30,31)$. Several natural and synthetic compounds have been identified as having ChAT stimulatory or inhibitory functions, consequently affecting the immune cells. The summary of the effect of ChAT activators and inhibitors is listed in Table $\mathbf{1 .}$

\section{Cholinesterase (ChE) and Cholinesterase Inhibitors (ChEl)}

The degradation of ACh into choline and acetate ions is regulated by acetylcholinesterase (AChE; EC 3.1.1.7) and butyrylcholinesterase (BChE; EC 3.1.1.7) enzymes, as shown in Figure 1. AChE is a 537-amino-acid protein that functions as a primary serine hydrolase. It has a recovery time of around 100 microseconds and can hydrolyze $6 \times 10^{5} \mathrm{ACh}$ molecules per minute (63). BChE is a nonspecific serine hydrolase capable of hydrolyzing broad choline-based esters, thus serving as a coregulator of cholinergic transmission (64). With a half-life of 20 
TABLE 1 | Effect of ChAT activators and inhibitors on the immune system.

\begin{tabular}{|c|c|c|c|}
\hline Molecules & Cholinergic effects & Effect of immune status & Experimental model \\
\hline Estradiol & Increases ChAT activity in the forebrain $(32,33)$. & $\begin{array}{l}\mathrm{CD}^{+} \mathrm{T} \text { cells, B cells, and macrophages express estrogen } \\
\text { receptors (34). Regulates innate immunity, antigen presentation, } \\
\text { and adaptive immune response and has a protective anti- } \\
\text { inflammatory effect (35). }\end{array}$ & $\begin{array}{l}\text { 1. Ovariectomized RA } \\
\text { mice (36). } \\
\text { 2. Cancer model ( } 37) \\
\text { 3. Autoimmune } \\
\text { disease (38) }\end{array}$ \\
\hline Trimethyltin (TMT) & $\begin{array}{l}\text { TMT increases ChAT activity in the dentate gyrus } \\
\text { (39). }\end{array}$ & $\begin{array}{l}\text { TMT treatment causes atrophy of the thymus, spleen, and lymph } \\
\text { nodes. Show reduced antibody levels, Iymphocyte proliferation, } \\
\text { NK cell function, and peritoneal macrophages' phagocytic activity } \\
(40,41) \text {. Induce microglial/astroglial activation (42). }\end{array}$ & $\begin{array}{l}\text { 1.TMT-induced } \\
\text { neurotoxic and seizure } \\
\text { model (43). } 2 \text {. } \\
\text { Autophagy-induced } \\
\text { Alzheimer and } \\
\text { epilepsy (44) }\end{array}$ \\
\hline A23187 & $\begin{array}{l}\text { Affect calcium ionophore and increases ChAT } \\
\text { expression in leukemic T cells. }\end{array}$ & $\begin{array}{l}\text { A23187 induces the expression of IL-2 receptors in purified T cells } \\
\text { (45). It stimulates the proliferation of allogeneic T cells and } \\
\text { increases DC-stimulated cytotoxic T lymphocytes (46). A23187 } \\
\text { treatment in macrophages causes leukotriene C4 release and } \\
\text { enhanced macrophage anti-tumor activity (47). }\end{array}$ & \\
\hline $\begin{array}{l}\text { Anti-thymocyte } \\
\text { globulin (ATG)- } \\
\text { Fresenius }\end{array}$ & $\begin{array}{l}\text { Upregulate ChAT expression mediated by CD11a } \\
\text { and ACh release through transient increases in } \\
\text { intracellular } \mathrm{Ca}^{2+}(48) \text {. }\end{array}$ & $\begin{array}{l}\text { ATG induced a semi-mature phenotype DC with a tolerogenic } \\
\text { phenotype that actively suppressed the T cell proliferation (49). } \\
\text { Negatively influence B-cell immune reconstitution and deplete } \\
\text { cytotoxic T cells (50). }\end{array}$ & $\begin{array}{l}\text { Solid-organ } \\
\text { transplantation and } \\
\text { allogeneic stem cell } \\
\text { transplantation in } \\
\text { human (51). }\end{array}$ \\
\hline Dibutyryl cAMP & $\begin{array}{l}\text { PKA activator upregulates ChAT mRNA expression } \\
\text { and ChAT activity and ACh production in the human } \\
\text { leukemic cell (52). Dibutyryl cAMP treatment on } \\
\text { adipocytes induced Chrna2 expression that controls } \\
\text { whole-body metabolism (53). }\end{array}$ & $\begin{array}{l}\text { Dibutyryl-cAMP induces the endogenous production of CAMP and } \\
\text { mimics the inhibitory effect of epinephrin on cytotoxic T } \\
\text { lymphocytes (54). Cyclic AMP suppress the production of IL-2 in T } \\
\text { cells but stimulate antigen-specific and polyclonal antibody } \\
\text { production in B cells (55). }\end{array}$ & - \\
\hline
\end{tabular}

Phorbol 12- Nonspecific PKC activator.

myristate 13-acetate It promotes the expression of both $M_{3} / M_{5} m A C h R$ (PMA) and ChAT mRNA in endothelial cells and spinal cord neurons. Thus, activating cholinergic signaling (56, 57).

Phytohemagglutinin Antigen-induced T cell activation via TCR/CD3 $\varepsilon$ (PHA) complexes enhances upregulation of ChAT and $\mathrm{M}_{5}$ mAChR expression (58).

Naphthyl-vinyl- NVP's method of ACh antagonism involves pyridine derivatives (NVP)

$\alpha-N E T A$ inhibiting the enzyme.

$\alpha-$ NETA exhibits a potent inhibitory activity of ChAT

PHA-activated lymphocytes respond to cholinergic stimulation with an increase in their free cytoplasmic $\mathrm{Ca}^{2+}$ levels.

LPS challenged Splenic Lymphocyte-derived ACh was prevented by cotreatment with NVP (59).

$\alpha$-NETA treatment significantly delays the onset of EAE. It antagonizes Chemokine-like receptor-1 (CMKLR1) and inhibits $\beta$ arrestin-2 cell migration (60).

Bromoacetylcholine Inhibits ChAT and carnitine acetyltransferase (CarAT) and activity to synthesize ACh

Synthesis of ACh was reduced by 50 percent in various leukemic

Bromoacetylcarnitine FK-506 (tacrolimus)

Reduces PHA-induced expression of ChAT mRNA and ACh synthesis through the calcineurin-mediated T cell lines upon inhibition of ACh synthesizing enzymes (61).

pathway

Treatment of MG

(62) to 60 days, AChE is predominantly found in the neuromuscular junction (NMJ), plasma, liver, and erythrocytes, while BChE is primarily found in the liver and blood plasma, with a reduced half-life of 10 to 14 days in these tissues $(65,66)$. The cholinergic system-specific catalytic activity of AChE/BChE degrades signal transmission by $\mathrm{ACh}$ and determines one's cholinergic status (CS) (67). Ubiquitous expression of AChE is found within mouse lymphocytes, DCs, and macrophages (68).

In two independent studies, serum AChE levels and CS were substantially higher in patients with irritable bowel syndrome (IBS), whereas CS was significantly lower in IBD patients (69, 70). AChE immunoreactivity was also higher in cirrhotic livers, suggesting a connection between CS dysregulation and GI diseases (71). The possible link of reduced AChE and BChE enzyme activity to proinflammatory processes through hydrolysis of ACh was evident in diseases like MS and AD (72, 73). ChE activity, in turn, can be modulated by ChE inhibitors (AChEIs and BChEIs), thereby increasing ACh levels in the body. The pharmacokinetic properties of ChEIs are thus exploited for the treatment of neurodegenerative and inflammatory diseases like myasthenia gravis (MG) and $\mathrm{AD}$ (74). Some ChEIs, such as donepezil, galantamine, and rivastigmine, are currently being used to treat $\operatorname{AD}(75,76)$. Some of the synthetic molecules that enhance or inhibit ChE and affect cholinergic transmission are listed in Table 2. While many of these molecules have been studied in the context of neurological diseases, how they modulate inflammation and autoimmunity is still under investigation. 
TABLE 2 | Modulators of the AChE enzyme.

\begin{tabular}{|c|c|c|c|}
\hline Molecules & Cholinergic effect & Effect on immune status & Applications \\
\hline $\begin{array}{l}\text { GAL } \\
\text { (Galantamine) }\end{array}$ & $\begin{array}{l}\text { Weak competitive and reversible ChEl } \\
\text { also allosterically modulates nicotinic } \\
\text { acetylcholine receptors. }\end{array}$ & $\begin{array}{l}\text { Treg suppressive activity is enhanced post GAL incubation (77). GAL sensitizes } \\
\text { microglial } \alpha 7-n A C h R s \text { and induces } \mathrm{Ca}^{2+} \text { influx signaling cascades that stimulate } A \beta \\
\text { phagocytosis in the AD model (78) GAL resulted in reduced mucosal inflammation } \\
\text { associated with decrease MHC II levels and proinflammatory cytokine secretion by } \\
\text { splenic CD11 } \mathrm{c}^{+} \text {cells (79). }\end{array}$ & $\begin{array}{l}\text { Improves cognitive } \\
\text { function in AD and } \\
\text { dementia (80). }\end{array}$ \\
\hline Rivastigmine & $\begin{array}{l}\text { Rivastigmine inhibits both AChE and } \\
\text { BChE in CNS. It preferentially inhibits } \\
\text { the G1 enzymatic form of AChE, } \\
\text { predominantly found in AD patients. }\end{array}$ & $\begin{array}{l}\text { Rivastigmine significantly decreases nitric oxide release, IL-1 } \beta, I L-6 \text {, and TNF- } \alpha \text { from } \\
\text { stimulated macrophages (81). In the EAE model, it reduces microglial activation, } \\
\text { encephalitogenic T cells proliferation, and TNF- } \alpha \text { and IFN- } \gamma \text { production (82). }\end{array}$ & $\begin{array}{l}\text { Used in improving } \\
\text { functional and clinical } \\
\text { symptoms of AD and } \\
\text { Parkinson's }(83,84)\end{array}$ \\
\hline Hup A & $\begin{array}{l}\text { A highly selective, centrally-acting } \\
\text { AChE inhibitor also antagonizes } \\
\text { NMDA receptors. }\end{array}$ & $\begin{array}{l}\text { HupA administration showed a reduction of proinflammatory cytokines TNF- } \alpha \text { and IL- } \\
1 \beta \text { in sepsis-associated encephalopathy. Increased expressions of ChAT and CHRM1 } \\
\text { attributed to reduced neuronal apoptosis and septic symptoms relief }(85,86) \text {. HupA } \\
\text { reduces proinflammatory cytokines (IFN- } \gamma \text { and IL-17) and chemokines in the EAE while } \\
\text { increases anti-inflammatory cytokines (IL-4 and IL-10 (4). }\end{array}$ & $\begin{array}{l}\text { Hup } A \text { is } \\
\text { administered for the } \\
\text { treatment of } A D \text { and } \\
\text { schizophrenia (86, } \\
87 \text { ) }\end{array}$ \\
\hline Neostigmine & $\begin{array}{l}\text { Blocks the active site of AChE and } \\
\text { has limited ability to pass the blood- } \\
\text { brain barrier. }\end{array}$ & $\begin{array}{l}\text { Neostigmine increases HLA-DR expression and stimulates TNF- } \alpha \text { production in resting } \\
\text { DCs. It significantly reduced TNF- } \alpha \text { and IL-12p70 production and prevented up- } \\
\text { regulation of HLA-DR expression triggered by LPS (26). }\end{array}$ & $\begin{array}{l}\text { It is administered for } \\
\text { neurophysiological } \\
\text { modifications in MG. } \\
\text { It is also used to treat } \\
\text { acute colonic } \\
\text { pseudo-obstruction, } \\
\text { Ogilvie syndrome, } \\
\text { and Gl disorders (88, } \\
\text { 89). }\end{array}$ \\
\hline $\begin{array}{l}\text { Pyridostigmine } \\
\text { (PY) }\end{array}$ & $\begin{array}{l}\text { A potent carbamate peripheral } \\
\text { inhibitor of AChE increases the } \\
\text { transmission of impulses from } \\
\text { cholinergic neurons across the } \\
\text { synaptic cleft. }\end{array}$ & $\begin{array}{l}\text { PY enhances anti-inflammatory response in HIV-1-infected patients by reducing T cell } \\
\text { proliferation and IFN- } \gamma \text { production and increases IL-4 and IL-10 expression (90). It has } \\
\text { a pro-eosinophilic effect through downregulation of IL-5, IL-13, and eotaxin in DSS- } \\
\text { induced colitis. It also attenuates DSS-induced microbiota dysbiosis and improves } \\
\text { epithelial integrity (91). Cholinergic modulation with PY induces greater recruitment } \\
\text { of M2 macrophages and circulatory Treg cells soon after myocardial infarction in } \\
\text { rats (92). }\end{array}$ & $\begin{array}{l}\mathrm{PY} \text { is used for the } \\
\text { management of MG } \\
\text { (93). Oral PY to be } \\
\text { helpful in different Gl } \\
\text { dysmotility (94). }\end{array}$ \\
\hline Physostigmine & $\begin{array}{l}\text { Interfere with acetylcholine signaling } \\
\text { such as atropine, scopolamine. }\end{array}$ & $\begin{array}{l}\text { Physostigmine significantly decreases the expression of IL-1 } 1 \beta \text {, TNF- } \alpha \text {, and IL-10 in the } \\
\text { spleen and plasma in mice models, along with reduced neurodegeneration in the } \\
\text { hippocampus (95). }\end{array}$ & $\begin{array}{l}\text { ChEl was first } \\
\text { investigated for the } \\
\text { treatment of AD } \\
\text { however discontinued } \\
\text { for multiple adverse } \\
\text { effects (96). }\end{array}$ \\
\hline $\begin{array}{l}\text { Ambenonium } \\
\text { chloride }\end{array}$ & $\begin{array}{l}\text { AChE inhibitor and down-regulates } \\
\alpha 6 \beta 2 \text {-nAChR mediated dopamine } \\
\text { release. }\end{array}$ & & $\begin{array}{l}\text { Reduce the } \\
\text { aggregation of the } \beta \text { - } \\
\text { amyloid peptide }(A \beta) \\
\text { and a prion-peptide } \\
\text { in } A D(97)\end{array}$ \\
\hline $\begin{array}{l}\text { Acotiamide } \\
\text { hydrochloride }\end{array}$ & $\begin{array}{l}\text { A selective, reversible AChE inhibitor } \\
\text { improved clonidine-induced } \\
\text { hypomotility. }\end{array}$ & & $\begin{array}{l}\text { Used for treatment of } \\
\text { functional dyspepsia } \\
\text { (98). }\end{array}$ \\
\hline Corydaline & $\begin{array}{l}\text { Inhibits AChE in a dose-dependent } \\
\text { manner. }\end{array}$ & $\begin{array}{l}\text { Inhibits pro-inflammatory cytokines expression (TNF- } \alpha \text {, IL-6) in LPS-challenged } \\
\text { macrophages. }\end{array}$ & \\
\hline Donepezil & $\begin{array}{l}\text { Centrally acting reversible AChEl and } \\
\text { also upregulates nAChR in neurons } \\
(99,100) \text {. }\end{array}$ & $\begin{array}{l}\text { It shows anti-inflammatory effects and prevents BBB degradation by modulating MMP- } \\
2 / 9 \text {, NGF/proNGF, IFN- } \gamma / \mathrm{IL}-4 \text {, and p-Akt in EAE (101). Pre-treatment with donepezil } \\
\text { suppressed TNF- } \alpha \text {-induced sustained intracellular } \mathrm{Ca}^{2+} \text { elevation via the PI3K } \\
\text { pathway in rodent microglial cells. It also suppresses NO production and increases the } \\
\text { phagocytic activity of mouse primary microglial cells (102). In macrophages, donepezil } \\
\text { reduces inflammatory cytokines (IL-1 } 1 \beta, \mathrm{IL}-2, \mathrm{IL}-6, \mathrm{IL}-18 \text {, and TNF- } \alpha \text { ) and attenuates } \\
\text { LPS-induced nuclear translocation of NF- } \kappa \mathrm{B} \text { (103). It inhibits RANK- } \\
\text { induced bone degradation by inhibiting osteoclast differentiation (104). }\end{array}$ & $\begin{array}{l}\text { It is mainly used to } \\
\text { treat } A D, P D \text {, } \\
\text { Schizophrenia, and } \\
\text { depression (105- } \\
\text { 106). }\end{array}$ \\
\hline $\begin{array}{l}\text { Choline } \\
\text { alfoscerate }(\alpha- \\
\text { GPC) }\end{array}$ & $\begin{array}{l}\text { Parasympathomimetic acetylcholine } \\
\text { precursor, acting as acetylcholine } \\
\text { release promoter (107). }\end{array}$ & - & - \\
\hline Cisapride & $\begin{array}{l}\text { Stimulate serotonin receptors } \\
\text { mediated increases of } \\
\text { acetylcholine release in the enteric } \\
\text { nervous system (108). }\end{array}$ & - & - \\
\hline Curcumin & $\begin{array}{l}\text { Stimulates vagus nerve and enhance } \\
\text { ACh biosynthesis by upregulating }\end{array}$ & - & - \\
\hline
\end{tabular}


TABLE 2 | Continued

\begin{tabular}{|c|c|c|c|}
\hline Molecules & Cholinergic effect & Effect on immune status & Applications \\
\hline & $\begin{array}{l}\text { enhanced ChAT activity and } \\
\text { expression of VAChT in murine RA } \\
\text { model. } \\
\text { (109) Upregulates gene expression } \\
\text { of } \mathrm{M}_{1} \text { and } \mathrm{M}_{3} \mathrm{mAChR} \text {, choline } \\
\text { acetyltransferase, and GLUT3 in the } \\
\text { cerebral cortex of diabetic rats (110). }\end{array}$ & & \\
\hline
\end{tabular}

\section{Choline Transporter (ChT) and Vesicular Acetylcholine Transporter (VAChT)}

ChTs are expressed on the cell membranes of cholinergic neurons in presynaptic terminals and regulate the ACh reservoirs during autonomic, cognitive, and motor functions (111). This membrane protein helps transport the precursor molecule choline into the neurons for the synthesis of ACh (111). ChTs are predominantly found on the plasma membrane of microvascular cells. They are also highly expressed on the mitochondrial membrane, where they are involved in choline oxidation upon absorption. Bone marrow-derived macrophages treated with lipopolysaccharide (LPS) show increased transcript and protein expression of the choline transporter-like protein-1 (CTL1) (112). The human leukemic T-cell line expresses CHT1 mRNA and mediates choline uptake in T cells (113). Activation of protein kinase C causes inhibition of CTL1 in macrophages, thereby causing altered cytokine secretion (114). The distribution of $\mathrm{ChT}$ on different immune cells and its importance in the specific tissue microenvironment in controlling inflammation and immunity need to be further investigated.

ACh is packaged into the secretory vesicles by a specific transporter protein VAChT using an exchange of protons $\left(\mathrm{H}^{+}\right)$ (115). Most cholinergic neurons in the brain, spinal cord, and NMJ with skeleton muscle express VAChT (116). Alteration of VAChT expression has consequences on the concentration of acetylcholine loaded in the secretory vehicle, thus indirectly maintaining the neurotransmitter release. Dysregulation of $\mathrm{VAChT}$ has been reported in several diseases like $\mathrm{AD}$, Epilepsy, and Sepsis (117-119). VAChT knockdown (VAChT$\mathrm{KD}$ ) mice, upon LPS challenge, show increased susceptibility to inflammation and greater mortality. LPS challenge increases the levels of proinflammatory cytokines (TNF- $\alpha$, IL- $1 \beta$, and IL- 6 ) in the spleen, brain (120). Human melanocytes, keratinocytes, and alpha-cells also express non-neuronal VAChT, thereby regulating the acetylcholine release and cholinergic activity $(121,122)$. The expression and function of VAChT on immune cells are still unclear and thus have potential physiological consequences in the peripheral immune response.

\section{Acetylcholine Receptors (AChRs)}

The diversified role of ACh is governed by different types of receptors, known as cholinergic receptors (AChRs), which are classified according to their affinity for various chemical ligands (123).

\section{Nicotinic Acetylcholine Receptors (nAChRs)}

These receptors respond to the ligand, nicotine. These ligandgated ion channels are composed of four distinct subunits ( $\alpha 1-$ $10, \beta 1-4, \gamma$, and $\delta$ ) bound in different stoichiometric ratios around a central pore with the help of $\epsilon$ subunits (Figure 2). These receptors exist as homomers (with all subunits of one type), such as $(\alpha 7)_{5}$, or as heteromers with at least one $\alpha$ and one $\beta$ subunit among the five subunits that are combined in various combinations, such as $(\alpha 4)_{3}(\beta 2)_{2},(\alpha 4)_{2}(\beta 2)_{3},(\alpha 3)_{2}(\beta 4)_{3}$, $\alpha 4 \alpha 6 \beta 3(\beta 2)_{2}$ (124). The structure of the human $\alpha 3 \beta 4-n A C h R$ complex, solved using cryoelectron microscopy (125), is shown in Figure 2. This structure shows a central channel formed by different subunits of nAChRs. The channels help move ions from the extracellular environment to the cytoplasmic side or vice versa in the cells after stimulation with specific ligands (Figure 2). The $\alpha 3 \beta 4-n A C h R$ subtype is located in the autonomic ganglia and adrenal glands, which forms the main relay between the central and peripheral nervous systems in the hypothalamic-pituitary-adrenal axis (HPA) axis upon activation (126). Diverse nAChR subtypes confer differential selectivity for nicotinic drugs in the central and peripheral nervous system, muscles, and many other tissues (127). The ligand binds to the specific site of the receptor leading to the triggering of all subunits of $\mathrm{nAChR}$ to change conformation, resulting in the opening of a non-selective cation channel, which then regulates the movement of ions (128).

In the immune system, nAChRs are known to regulate inflammatory processes (129). Pathological causes in acquired neurodegenerative diseases, such as autoimmune ganglionopathy, autoimmune encephalitis, and MG, are caused by an autoimmune reaction against nAChRs in the NMJ (130-132). Non-neuronal $\mathrm{nAChRs}$ are also involved in the pathogenesis of palmoplantar pustulosis, psoriasis, and rheumatic diseases (133-135). Overexpression of nAChR in gastric, colorectal, pancreatic, liver, lungs, and breast tumors appears to regulate cancer cell processes such as proliferation, apoptosis, angiogenesis epithelialmesenchymal transformation $(136,137)$. Several of the nAChR agonists and antagonists are known to work in a receptor-specific and selective manner. Some of the agonists and antagonists are listed in Tables 3 and $\mathbf{4}$. Treatment with these ligands and their 


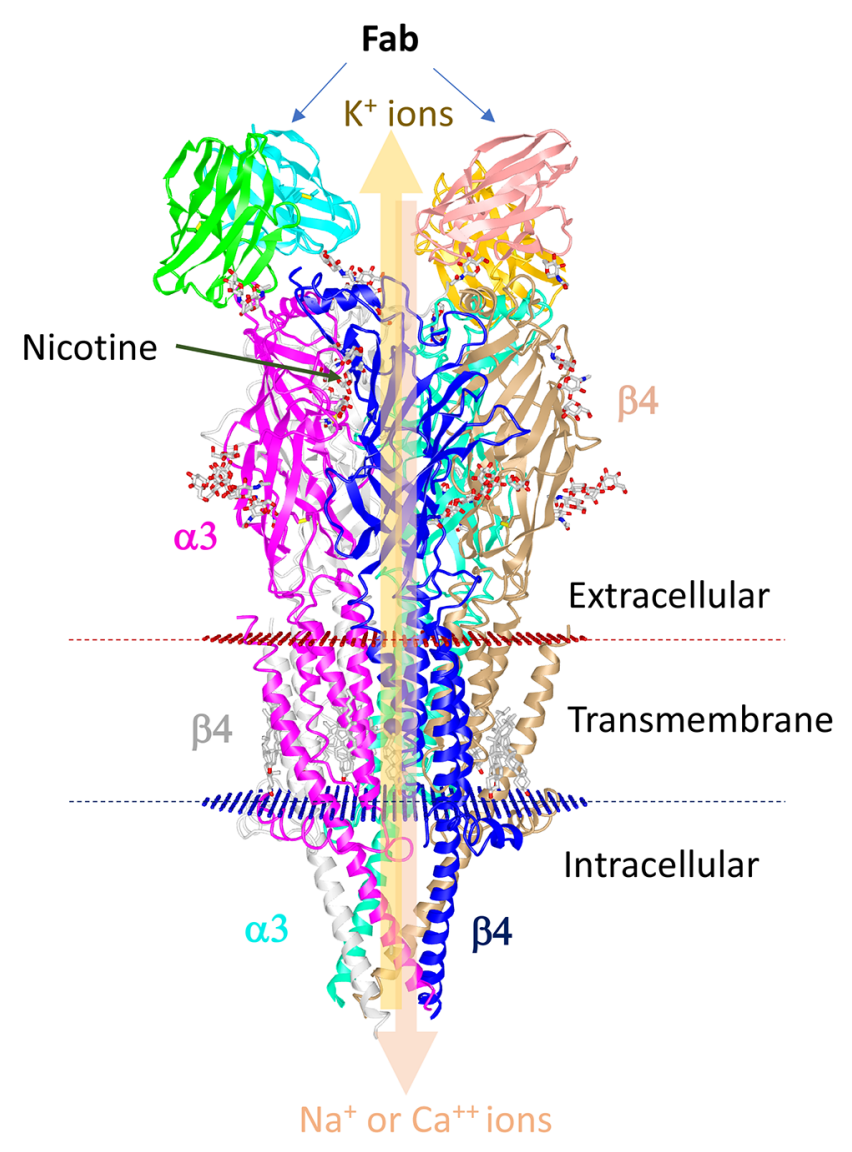

FIGURE 2 | Structure of human $\alpha 3 \beta 4-n A C h R$ complexes with nicotine. The human nAChR complex with $\alpha 3 \beta 4$ nicotine acetylcholine receptor (Protein data bank Id: 6PV7) is displayed using the online iCn3D software. The structure is composed of two $\alpha 3$ chains and three $\beta 4$ chains. The Fab fragments of the antibody used for stabilization of the sample are shown at the top. Nicotine is shown in balls and sticks. Red and blue discs represent the plasma membrane. The thick arrow depicts the regulation of the movement of ions by the central pore.

effect on immune cells is not very well studied and needs detailed investigation.

\section{Muscarinic Acetylcholine Receptors (mAChRs)}

These are metabotropic receptors consisting of seven transmembrane subunit G protein-coupled receptors (GPCRs) that respond to ACh and muscarine (248). $M_{1}$ to $M_{5} \mathrm{mAChR}$ subtypes share 64 to 68 percent sequence identity and 82 to 92 percent sequence similarity, indicating that they have a high degree of sequence homology. Their G-protein coupling preferences and physiological functions, however, are different. $\mathrm{mAChRs}$ have been separated into two groups based on their functional coupling. The $\mathrm{M}_{1} \mathrm{mAChR}, \mathrm{M}_{3} \mathrm{mAChR}$, and M5 mAChR are coupled to $G_{\mathrm{q} / 11}$ proteins, which mediate the activation of phospholipase C (PLC) activity (249). The $M_{2} \mathrm{mAChR}$ and $\mathrm{M}_{4} \mathrm{mAChR}$ are coupled to the $\mathrm{G}_{\mathrm{i} / \mathrm{o}}$ protein, which mediates inhibition of adenylate cyclase (AC) and thus causes a decrease in cyclic adenosine monophosphate (cAMP) (248). Based on the physiology and distribution of the individual receptor, $\mathrm{mAChRs}$ can trigger different signal transduction pathways in the cells in a tissue-specific manner. Recently, the structures of the human $M_{1} m A C h R$ and $M_{2}$ mAChR2 with G-protein complexes were published (250). The structure visualization of human $\mathrm{M}_{1} \mathrm{mAChR}$ with the G-protein complex is shown in Figure 3. mAChRs have an extracellular ligand-binding domain and a transmembrane and intracellular signaling domain. The intracellular domain interacts with $G$ proteins and other signaling molecules and helps intracellular signaling (Figure 3). mAChRs are abundant in the hippocampus, cortex, thalamus, gastric and salivary glands, smooth muscle, and cardiac tissue, each having a specific downstream signaling cascade. Thus, the structural differences, ligand specificity, and functioning mechanism help understand each receptor's roles within specific tissues. In the murine endotoxemia model, muscarinic receptor-mediated cholinergic signaling in the forebrain regulates peripheral immune function and inflammation to suppress serum TNF- $\alpha$ levels (251). Conversely, the major cause for the pathogenesis of autoimmune Sjögren's syndrome is the production of autoantibodies against the $\mathrm{M}_{3} \mathrm{mAChR}$ (252). Autoantibodies 


\section{Pan-cholinergic agonists}

Acetylcholine chloride Non-selective cholinergic agonist mimics the effect of the endogenous compound acetylcholine.

Carbachol Non-selective cholinomimetic agonist stimulates both muscarinic and nicotinic receptors.

\section{Selective to nicotinic receptors}

Nicotine Nicotine induces non-selective activation of nAChRs.

Cotinine Activates, desensitizes nAChR at a much lower potency than nicotine.

ABT-418

Epibatidine

Binds to the $\alpha 4 / \beta 2$-nAChR and also binds to the $\alpha 3 / \beta 4-n A C h R$ subtype.

Succinylcholine

chlorid

Irreversible and competitive agonist on muscle type $(\alpha 1) 2 \beta 1 \delta \epsilon-n A C h R(153)$. It is resistant to acetylcholinesterase and is quickly degraded by plasma butyrylcholinesterase.

PNU-282987 Selective $\alpha 7$-nAChR agonist

Cris-104

Neuronal $\alpha 4 \beta 2-n A C h R$ agonist

PHA-543613

Selective $\alpha 7-n A C h R$ agonist

NS6740

GAT107
Silent non-ionotropic agonist of $\alpha 7$-nAChRs but an effective modulator of the cholinergic anti-inflammatory.

Positive modulator of $\alpha 7$-nAChR
Its multi-faceted action, toxicity, and rapid inactivation by cholinesterase do not offer a therapeutic value.

Carbachol treatment reduces the expression of IL-1ß; MHC-II, CD86, and IL-12p70 Used for treatment of glaucoma in humans (141). in splenic DCs at the early phases of sepsis (138). It reduces the release of inflammatory cytokines (TNF- $\alpha$, IL-1 $\beta$, and IL-6) and expression of caspase- 3 myocardial cells and improves the cardiac function and survival rate from sepsis in rats (139). Carbachol increases the expression of inflammatory genes (IL-6, IL-8, and cyclooxygenase-2) in smooth muscles (140).

Nicotine-treated cells produce lower Th1 cytokines (IL-2 and IFN- $\chi$ ), but significantly higher Th2 cytokines (IL-4 and IL-10) (142). Nicotine suppresses IL-18-mediated systemic inflammatory responses and downregulates expression of TNF- $\alpha$, IL-12, and IFN- $\gamma$ in PBMCs (143).

A high cotinine concentration stimulates extracellular ROS generation and oxidative stress-mediated tissue damage by activated neutrophils (146). Pre-treatment of monocytes with cotinine mounts IL-10-dominated anti-inflammatory response via a7-nAChR through PI3K/GSK-3ß-dependent pathway (147).

ABT-418 has a neuroprotective effect on rat cortical cells to glutamate (Glu)induced cytotoxicity mediated via interaction with $\alpha 7$-nAChRs (148).

Stimulation of $\alpha 4 \beta 2 \mathrm{nAChRs}$ with epibatidine increases the IgM-mediated proliferation of B cells (151). In vivo administration of epibatidine (5 $\mu \mathrm{g} / \mathrm{kg}$, s.c.) increases plasma corticosterone levels and reduces the lymphocyte proliferation in the presence of concanavalin A (152).

Patients who received succinylcholine as an anesthetic had lower CD4/CD8 frequency and lgE levels in their peripheral blood. It also changes the oxidative state of lymphocytes by impairing glutathione levels and prompting $T$ cells to produce more reactive oxygen species (ROS) $(154,155)$.

PNU-282987 has a protective function in the lung injury model. PNU-282987 inhibits TNF- $\alpha$ and IL-6 release and decreases the phosphorylation levels of $p 38$, JNK, and ERK in peritoneal macrophages (156). In the bronchoalveolar microenvironment, PNU-282987 reduces the neutrophil recruitment and inflammatory cytokines secretion (157). It also has an anti-inflammatory role in NK cells by reducing the NF- $\mathrm{KB}$ levels and its translocation to the nucleus, downregulating the expression of NKG2D receptors, and inhibiting IFN- $\gamma$ secretion and NKG2D-dependent NK cell cytotoxicity (158)

Cris-104 increases nor-epinephrine concentration and increases neuronal activity in the brain, thus having an anti-nociceptive efficacy in rodent models of acute and chronic pain (161).

PHA-543613 suppresses CDC42 and MMP2 mRNA expression in macrophages (162). Administration of PHA-543613 induces activation of PI3K/AKT/GSK-3 $\beta$ to reduce neuroinflammation and oxidative stress $(163,164)$.

S6740 shows an anti-inflammatory property in LPS challenge microglial cells by reducing TNF- $\alpha$ release (167)

GAT107 shows a dose-dependently attenuation of CFA-induced inflammatory pain by reducing phosphorylation of intracellular p38MAPK (168). In macrophages,
Nicotine has anti-inflammatory and depressive activity in neurodegenerative and depressed patients $(144,145)$.

A clinical trial of ABT-418 was conducted to treat adults with attention deficit hyperactivity disorder and $A D(149$ 150).

has been used as an anti-inflammatory therapy in anima models of diseases such as airway inflammation,

cardiomyopathies, and AD (159-160).

It's being studied as a potential cure for cognitive deficits in chizophrenia, PD, and intracerebral hemorrhage (165, 166).

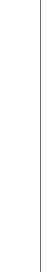


GAT107 improves superoxide dismutase 1 activity, Nrf2, and hemeoxygenase-1

AR-R17779

Selective $\alpha_{7}$-nAChR agonist

Nifene

Selective $\alpha 4 \beta 2-n A C h R$ receptor partial agonist

\section{Selective to muscarinic receptors}

Muscarine

Non-selective agonist of the mAChR (175). It has both excitatory and inhibitory effect on ACh release at NMJ due to differential binding to various mAChRs.

L-Satropane mAChR agonists

Oxotremorine (Oxo-M) Non-selective (mAChR) agonists with positive allosteric modulation via $\mathrm{M}_{4}$ subtype.

McN-A-343

Selective M1 mAChR agonist, however, is mAChR.

Cevimeline

Bethanechol chlorid $\mathrm{mAChR}$ and $\mathrm{M}_{3} \mathrm{mAChR}$.

Muscarinic agonist selectively activates $M_{2}$ mAChR.

Arecaidine propargyl

Ester (APE) and

Arecaidine But-2-yny

Ester Tosylate (ABET)

7,8-dihydroxyflavone

(7,8-DHF)

Amiodarone

Highly selective $M_{1} m A C h R$ and $M_{2} m A C h R$ agonist.

Positive allosteric modulator increased $\mathrm{M}_{3}$ mAChR.

Gq-mediated responses are positively modulated at $\mathrm{M}_{1} \mathrm{mAChR}$ and $\mathrm{M}_{3} \mathrm{mAChR}$ but inhibited in a more discriminating fash at the $M_{1} \operatorname{mAChR}(194,195)$.

Xanomelin $M_{1} / M_{4}$ mAChR preferring muscarinic agonist.

Dihydroquinazolinone

Selective and CNS-penetrant $\mathrm{M}_{1} \mathrm{mAChR}$

Clozapine Agonist at the $\mathrm{M}_{4} \mathrm{mAChR}$ and antagonized expression (169) partial agonist with a similar affinity at all five

Stimulates SSN neurons mainly by $M_{1}$ and $\mathrm{M}_{4} \mathrm{mAChR}$ agonists.

AR-R17779 has a protective role mediated by $\alpha_{7}$-nAChR in intestinal colitis and post-operative infections model $(170,171)$. In CFA-induced arthritis, it plays a contradictory role. It decreased TNF- $\alpha$ levels in plasma and synovial tissue, as well as exacerbates arthritis $(172,173)$.

${ }^{8} \mathrm{~F}-$ Nifene is used in PET and SPECT imaging agents to screen lung cancer (174).

Intravenous administration of muscarine chloride increases IgA secretion from the perfused intestinal loops in rats (176).

L-satropane defends against $\mathrm{CoCl}$-induced neurotoxicity by increasing retinal neuron survival in a dose-dependent manner. L-satropane substantially reverses the $A \beta$ production (177).

Oxo-M promotes TCR/CD3E-induced IL-2 secretion in human PBMCs. It also increases the cell surface expression of CD2, CD3, CD4, CD8, and IL-25 (178,

179) and promotes $T$ cell proliferation (180)

McN-A 343 therapy results in a substantial reduction in colitic score. McN-A-343 therapy reduced colonic inflammation and decreased pro-inflammatory Th1/Th17 colonic and splenic DC cytokine secretion mediated by the 7nAChR and NF-kB signaling pathways. $C D 4^{+} T$ cell priming was diminished after cholinergic activation (181) McN-A-343 inhibits endotoxin-induced systemic TNF- $\alpha$ levels in a dosedependent manner (182)

Suppresses tumorigenesis through MAPK and PI3K/AKT signaling (184). Bethanechol treatment of bone marrow-derived macrophages upregulates $M_{3}$ mAChR gene expression and induces a classically-activated macrophage phenotype (185).

APE treatment inhibits the proliferation of cancer stem cells in glioblastoma multiforme by lowering the expression of mir210 in hypoxia conditions (189).

It inhibits iNOS and COX-2 expression and reduces the synthesis of NO and PGE2. Besides, 7,8-DHF blocks the release and expression of inflammatory cytokines such as TNF- $\alpha$ and IL-1 $(190,191)$.

TNF- $\alpha$, IL-6, of IL-1 $\beta$ production, was inhibited by amiodarone at $0.1-1 \mu \mathrm{M}$ concentration. Modulation of $1 \mathrm{~L}-6$ and $\mathrm{L}-1 \beta$ production by amiodarone was

Xanomelin suppresses TNF- $\alpha$ and IL-6 levels and improves survival in an endotoxemia model. Treatment with ex vivo endotoxin-stimulated splenocytes shows significantly less sensitivity to inflammatory activation and lower secretion of TNF- $\alpha$, IFN- $\gamma$, MCP1, IL-6, and IL-10 (199).

It shows a potent inhibitor of p38alpha MAP kinase and suppresses TNF- $\alpha$ production in LPS-stimulated PBMCs (202).

Clozapine inhibits T-bet expression and promotes STAT6 and GATA3 expression in It is a highly effective antipsychotic medication (206). agonist-induced responses at the other four mAChR.

PBMCs (203). Clozapine therapy inhibits the production of IL-6, IL-8, and IL-12 and increases the production of IL-10 in LPS-stimulated macrophages (204). In neutrophils, clozapine increases cell surface Mac-1 expression and activates the AKT signaling pathway and phagocytosis of bacteria (205).
Orally administered in the treatment of Sjogren's syndrome (183).

It has a bactericidal effect and increases intracellular cyclic GMP levels in the patient suffering from hidradenitis suppurativa (186). Administered to treat urinary retention and gastrointestinal motility $(187,188)$.

It shows a therapeutic efficacy for treating Alzheimer's disease, Huntington's disease, and schizophrenia in the animal model (192-193).

Amiodarone is an anti-arrhythmic drug used to treat severa congestive heart failure $(197,198)$.

It was used in the treatment of both Alzheimer's disease and schizophrenia (200-201). 
TABLE 4 | Antagonists of selective acetylcholine receptors (AChRs).

\begin{tabular}{ll}
\hline Antagonists & \multicolumn{1}{c}{ Cholinergic effects } \\
\hline $\begin{array}{l}\text { Selective to nicotinic receptors } \\
\text { Hexamethonium }\end{array}$ & Nicotinic receptor blocker \\
& \\
& Bind to nAChRs in an \\
BTX $)$ & irreversible antagonistic \\
& manner, blocking ACh's activity \\
& at the post-synaptic \\
& membrane, inhibiting channel \\
& opening and ion flow, and \\
& cause paralysis (209). \\
& To neutralize the effects of \\
& nicotine, it is used as a \\
& competitive non-selective \\
& $(\alpha 3 \beta 4, \alpha 4 \beta 2, \alpha 3 \beta 2$, and $\alpha 7)$ \\
nAChR antagonist
\end{tabular}

Dihydro-beta-erythroidine Selective $\alpha 4 \beta 2-n A C h R$ antagonist (161).

Dextromethorphan (DXM) $\alpha 3 \beta 4-n A C h R, \alpha 4 \beta 2-n A C h R$, and $\alpha 7-n A C h R$ antagonist in the cholinergic pathway (212). Also, It is a selective antagonism of N-methyl-Daspartate receptors and/or show interaction with opiate receptors (213).

Methyllycaconatine (MLA) $\quad \alpha 7-n A C h R$ antagonist

$\mathrm{N}, \mathrm{N}$-decane-1,10-diylbis-3-picolinium diiodide (bPiDI)

$\alpha$-conotoxins

SR16584
Selective $\alpha 6 \beta 2-n A C h R$ antagonist (222). Nicotineevoked dopamine activation and nicotine reinforcement are mediated by $\alpha 6 \beta 2-n A C h R s$ expressed by dopaminergic neurons. bPiDI blocks nicotine's effects on these receptors, making them therapeutic targets for nicotine addiction (223). Specific to $\alpha 3 \beta 2-n A C h R$, $\alpha 9 \alpha 10-n A C h R$, and $\alpha 3 \beta 4-$ nAChR (224). High affinity for $\alpha 3 \beta 4-n A C h R$ and $10 \mathrm{nM}$ for $\alpha 4 \beta 2-\mathrm{nAChR}$ (227, 228).
Hexamethonium blockade of peripheral nAChR increases neutrophil migration and mechanical hyperalgesia in the RA model (207). It suppresses stress-induced mast cell activation and inhibits elevated PGE2 levels after exposure to stress (208). $\alpha$-BTX treatment to T cells activated by sub-optimal PHA concentrations causes blockade of $\alpha 7$-nAChR that enhance T cell proliferation (210).

Mecamylamine reverses the ant-inflammatory role of nicotine in the nAChR-mediated cholinergic pathway.

Effect on immune status

Experimental models

Mecamylamine is licensed for the treatment of hypertension. It attenuates all of the nicotine and cigarettes symptoms, including seizures, rendering it an important pharmacotherapy for tobacco addiction (211). $-$

DXM decreases the expression of CD40, CD80, CD86, MHC class I, and MHC class II in both murine BMDCs and human monocyte-driven DCs upon LPS challenge. DXM pre-treatment results in dose-dependent substantial reductions in TNF- $\alpha, \mathrm{IL}-6, \mathrm{IL}-12$, and ROS production. It inhibits the ability of LPS-stimulated BMDCs to promote ovalbumin-specific $T$ cell proliferation by downregulating MAPK and NF- $\kappa$ B pathways (214). DXM is neuroprotective in cerebral ischemia models, spinal cord injury, PD, and epilepsy by downregulating NADPH oxidase, thus, reducing superoxide free radicals and intracellular (ROS) $(215,216)$. It prevents immune cell filtration, inhibits NOX2 activity, and has an anti-inflammatory effect in EAE (217). Proinflammatory cytokines (TNF- $\alpha, I L-6$, and IL-17A) expression levels decrease in CIA mice and RA patients. In collagen-reactive $\mathrm{CD}^{+}{ }^{+} \mathrm{T}$ cells, DXM reduced the production of anti-Cll $\operatorname{lgG}$, IFN- $\gamma$, and IL-17A (218).

MLA (2.4 mg/kg per day) treatment in acute viral myocarditis increases the frequency of Th1 and Th17 cells, lowers the frequency of Th2 and Treg cells in the spleen. It also increases proinflammatory cytokines, cellular infiltration, and severity of myocardium lesions in viral myocarditis (221).

$\alpha$-conotoxins $(5.5 \mu \mathrm{M})$ increases IL-10 production in Tregs and decreased IL-17 production in T cells (225). In PMA-activated macrophages, $\alpha$-conotoxins upregulate the TNF- $\alpha$ and IL-6 in a concentration-dependent manner (226).
DXM is under development for depression, AD ALS, and neuropathic pain (219-220). the treatment of

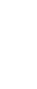


TABLE 4 | Continued

\section{Antagonists \\ Cholinergic effects \\ 18- Highly selective $\alpha 3 \beta 4-n A C h R$ \\ methoxycoronaridine (18- antagonist (229).}

Effect on immune status

Experimental

models
$\mathrm{MC)}$

AT-1001
High-affinity and selective to

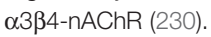

MG 624

$\alpha 7-n A C h R$ antagonist (232).

\section{Selective to muscarinic receptors}

Atropine

Hyoscyamine

Scopolamine

hydrobromide

Gallamine Triethiodide

VU0255035

Pirenzepine

Methoctramine

AF-DX 384

Darifenacin

4-diphenylacetoxy-N-(2- Selective $M_{1} / M_{3}$ mAChR chloroethyl)-piperidine (4- antagonist.

DAMP mustard)

Tropicamide
A nonspecific antagonist that competitively inhibits acetylcholine (ACh) at postganglionic muscarinic sites and CNS (232). Abolish the effect of vagus nerve stimulation.

Non-competitively inhibits acetylcholine (ACh).

A non-selective muscarinic acetylcholine receptor (mAChR).

Non-competitive inhibition by altering the affinity of the agonist for its binding site. Selective $M_{1} m A C h R$ antagonist Selective $M_{1}$ mAChR selective antagonist.

Selective $\mathrm{M}_{2} \mathrm{mAChR}$ antagonist

Selective $M_{2} m A C h R$ and $M_{4}$ mAChR antagonist.

Selective $\mathrm{M}_{3} \mathrm{mAChR}$ antagonist
Prior to the LPS-induced activation of the inflammatory response, atropine decreases TNF- $\alpha$ and raises $\mathrm{IL}-10$ plasma levels without affecting IL- 6 production. This reduction in TNF- $\alpha$ improved the rate of survival from endotoxic shock in mice (233).

Suppresses $T$ cell proliferation and proinflammatory cytokine production in turpentineinduced inflammation. In reaction to the potent neutrophil/macrophage chemoattractant $\mathrm{AMLP}$, atropine therapy decreases both chemokinesis and chemotaxis of PBMCs $(234,235)$.

In the acute lung injury model in rats, hyoscyamine derivatives cause substantial reductions in TNF- $\alpha, \mathrm{IL}-6, \mathrm{IL}-1$, and p38MAPK, NFB, and AP1 activation, as well as TLR4 expression (236).

Scopolamine hydrobromide treatment shows upregulation of TLR3, TLR7, TLR8, and cytokines such as IL-4 and IL-10 (237). Mice treated with scopolamine show an increased density of $\mathrm{CD}^{+}, \mathrm{CD} 11 \mathrm{c}^{+}$, and $\mathrm{CD} 11 \mathrm{~b}^{+}$cells. And also show elevated levels of IL-1 $\beta, I L-2, I L-6, I L-12 R \beta 1, I L-17 A$, IL-17R, IFN- $\gamma$, and TNF- $\alpha$ transcripts (238).

-
In humans with Th1-mediated celiac disease, it plays a therapeutic role by inhibiting cell permeability (231).

Used for treatment of motion

sickness, and Gl obstruction (239, 240)

Used in peptic ulcers and also reduces muscle spasms (241, 242). inhibits systemic TNF- $\alpha$ release by activating muscarinic receptors (182). Methoctramine abolishes the ACh-elicited anti-apoptotic property and reduces the TNF- $\alpha$-activated apoptotic pathway via EGFR-PI3K signaling in cardiomyocytes (243).

4-DAMP abolishes mAChR-mediated immunoglobulin class switching to IgG in B cells. It inhibits the production of IL-6 and the maturation of B cells into IgG-producing plasma cells (245). $\mathrm{M}_{3} \mathrm{mAChR}$-mediated IL-8 expression in regulating inflammatory response via PKC/NF- $\mathrm{KB}$ signaling axis is completely antagonized by 4-DAMP (246). It also inhibits human T cell growth by inhibiting M1 mAChR-mediated expression of both IL-2 and IL-2R (179).

Inhibiting

cholinergic

stimulation

responses,

producing dilation of the pupil and relaxation of the ciliary muscle in ophthalmic surgery (247). 


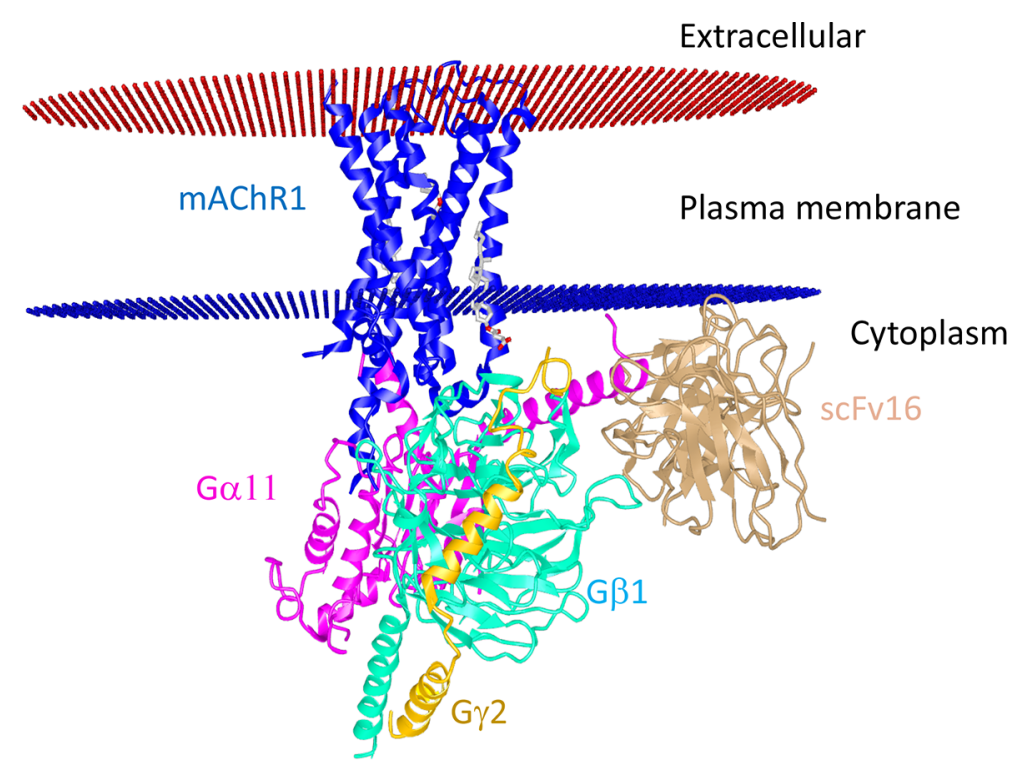

FIGURE 3 | Structural interaction of $\mathrm{M}_{1} \mathrm{mAChR}$ with the $\mathrm{G}$ protein-coupled receptor. The human muscarinic acetylcholine receptor $1 \mathrm{G} 11$ protein complex (Protein data bank ld: $6 \mathrm{OlJ}$ ) structure (3.3 A resolution) is displayed using the online iCn3D software. $\mathrm{M}_{1}$ mAChR interacts with G-proteins $\alpha 11$ and $\gamma 2-\beta 1$. The scFV16 nanobody used for stabilizing the structure is also shown. The allosteric ligand is shown in the ball and stick. Red and blue discs represent the plasma membrane.

against muscarinic receptors also triggered chronic immune activation in patients with chronic fatigue syndrome and periodontitis $(253,254)$. Patients with airway inflammatory infections/allergic rhinitis had increased expression of $\mathrm{M}_{3}$ mAChR mRNA and protein (255). However, the specific patterns of $\mathrm{mAChR}$ subunit distribution in tissues and expression in particular immune cell types are not well defined. Some of the selective mAChR agonists and antagonists are listed in Tables 3 and 4, respectively. Given the diverse distribution of mAChRs in different immune cells, the mechanism by which selective ligands alter specific immune cells in the tissue microenvironment during inflammation and immunity needs detailed investigation.

\section{The Role Played by the Cholinergic System in Various Immune Cells}

The neuronal and lymphoid cholinergic system evokes various downstream functional and biochemical effects through AChRs present on immune cells. The importance of different components of the complex cholinergic system in different immune cells is discussed below-

\section{Role in T Cells}

$\mathrm{T}$ cells and their effector and regulatory function play an important role in inflammation and autoimmunity $(256,257)$. Some splenic and intestinal $\mathrm{T}$ cell subsets have been found to express functional ChAT and produce ACh (ChAT ${ }^{+} \mathrm{T}$ cells) (21, 258). Most of these $T$ cell subsets are found in the vicinity of catecholamine splenic nerve fibers forming a cholinergic nonneuronal reservoir (259). The ACh produced in the microenvironment activates $\alpha 7-\mathrm{nAChR}$ on $\mathrm{T}$ cells and facilitates the activation and proliferation of $\mathrm{T}$ cells (260). In vitro administrations of nicotine or ACh in a micromolar range inhibits DC mediated-T cell proliferation and differentiation, as well as reduce CD28 and cytotoxic T-lymphocyte-associated protein 4 (CTLA-4) expression and diminished maturation in $\mathrm{T}$ cells $(261,262)$. Endogenously released ACh in human leukemic $\mathrm{T}$ cell upregulates several $\mathrm{Ca}^{2+}$-permeable ACh-gated ion channels. Nicotine also impairs antigen receptor-mediated signal transduction in lymphocytes and causes $\mathrm{T}$ cell anergy by arresting cells in the G0/G1 phase (263). It is also known to alter the expression of co-stimulatory and adhesion molecules (such as ICAM and CD44) on immune cells and suppress the production of inflammatory cytokines (TNF- $\alpha$, IFN- $\gamma$, and IL6) (264). Nicotine binds to various forms of nAChR on T cells with variable affinity and mediates the apparently paradoxical effects of fostering cell survival while also causing apoptosis by inducing expression of FasL and survivin gene (265). The receptors, $\alpha 7-n A C h R s$ and $\alpha 4-n A C h R$ are predominantly known to be involved in $\mathrm{CD}^{+} \mathrm{T}$ cell proliferation and function $(266,267)$. The $\alpha 7-\mathrm{nAChR}$ antagonist, $\alpha$ bungarotoxin ( $\alpha$-BTX), and methyllycaconitine (MLA) show an increased proliferative response to the $\mathrm{T}$ cell mitogen, phytohemagglutinin (PHA) (268). Activation of the $\alpha 7-n A C h R$ by nicotine in experimental autoimmune encephalomyelitis (EAE) mice model ameliorate clinal symptoms by directing naive $\mathrm{CD} 4^{+} \mathrm{T}$ cells towards the IL-4-producing Th2 phenotype and subsequently leads to decreased production of Th1 cytokines (such as TNF- $\alpha$, IFN- $\gamma$, IL-2) and Th17 cytokines (such as IL-17, IL-17F, IL-21, and IL-22). However, activation of $\alpha 7-n A C h R$ with agonist does not affect the differentiation of Th17 cells (269). $\alpha 7-n A C h R$ activation with nicotine in human PBMC and $\mathrm{CD} 4{ }^{+} \mathrm{T}$ cells results in a similar reduction of IL-17 production, suggesting that it has an anti-inflammatory property (270). 
Nicotine-induced activation of $\alpha 7-n A C h R s$ also increases the suppressive function of $\mathrm{CD} 4^{+} \mathrm{CD} 25^{+}$Tregs $/ \mathrm{CD} 4^{+} \mathrm{CD} 25^{-} \mathrm{T}$-cell by up-regulation of CTLA-4 as well as Foxp3 expression and decreased IL-2 secretion (271). These studies suggest that nAChRs activation can modulate the function of various subsets of $\mathrm{CD} 4^{+} \mathrm{T}$ cells.

In humans, all five subtypes of mAChRs are known to be expressed on lymphocytes. However, each receptor's expression pattern differs among different cell types in an individual (29). PHA is known to increase $\mathrm{M}_{5}$ mAChR mRNA expression in vitro, while lymphocytes stimulated with phorbol 12-myristate 13-acetate (PMA), a protein kinase $\mathrm{C}$ activator, plus ionomycin, a calcium ionophore, increase $\mathrm{M}_{3}$ and $\mathrm{M}_{5}$ mAChR mRNA expression, demonstrating that differential expression of $\mathrm{mAChR}$ is caused by different immunological stimulations (272). Activation of the $\mathrm{M}_{3} \mathrm{mAChR}$ using methacholine on $\mathrm{CD}^{+} \mathrm{T}$ cells isolated from airway inflammatory infections/ allergic rhinitis patients leads to increased production of IL-4 and TNF- $\alpha$ (255). Treatment of Jurkat cell lines with the mAChR agonist, oxotremorine (OXO-M), increases the expression of IL2 receptors on lymphocytes and enhances the PMA-induced IL-2 secretion (273). Interestingly, it was found that arecoline, a nonselective muscarinic agonist improves cognitive function and memory in $\mathrm{AD}$ (274). Chronic treatment with arecoline leads to a reduction in the size of the spleen, thymus, and mesenteric lymph nodes, as compared to untreated control mice. In-vitro arecoline treatment was shown to reduce lymphocyte proliferation and IL-2 production (275). $\mathrm{M}_{3} \mathrm{mAChR}$ knockout $\left(\mathrm{M}^{-/-}\right)$mice were reported to have trouble in clearing bacterial and helminth infections. The absence of $\mathrm{M}_{3} \mathrm{mAChR}$ also led to delayed expulsion of Nippostrongylus brasiliensis due to inhibition of smooth muscle contraction, a reduction in the activation of $\mathrm{CD}^{+} \mathrm{T}$ cells, and lower levels of expression of IL-4 and IL-13. The activation of the $\mathrm{M}_{3} \mathrm{mAChR}$, specifically with ACh on activated T cells, increases IL-13 and IFN- $\gamma$ cytokine production (276). The distribution of the $M_{1}-M_{5} m A C h R$ on each subset of $\mathrm{CD}^{+} \mathrm{T}$ cells in humans and mice has not been systemically studied and is therefore open for further investigation.

\section{Role in B Cells}

Mouse $B$ cells are known to express $\alpha 4, \alpha 5, \alpha 7, \beta 2$, and $\beta 4$ subunits of $\mathrm{nAChR}$, with the expression of different subunits being regulated at the various stages of B cell maturation (277). At the primary level, nAChRs are required for the development and survival of B lymphocytes within the primary lymphoid tissues and spleen. $\alpha 4$ and $\beta 2$ knockout mice have reduced B cell populations, underscoring their critical role in regulating lymphocyte survival (278). The $\mathrm{CD} 19^{+} \mathrm{B} 220^{+} \mathrm{IgM}^{+} \mathrm{B}$ lymphocytes mainly expressed $\alpha 7, \alpha 4$, and $\beta 2$ subunits of nAChRs. Mice deficient in these subunits of nAChRs showed reduced amounts of serum IgG, while $\beta 2^{-/-}$mice had a reduced number of IgG-producing cells in the spleen. However, the IgG response to horse cytochrome $c$ in $\alpha 4$ and $\beta 2$ knockouts was stronger than in wild-type (WT) mice, with the $\beta 2^{-/-}$mice having high cytochrome $c$-specific antibodies after immunization (279). Also, $\alpha 7-\mathrm{nAChR}$ influences IgM antibody production but not IgM to IgG class switching (280). $\alpha 7-n A C h R$ is constitutively expressed on $\mathrm{CD} 5^{+} \mathrm{CD} 1 \mathrm{~d}^{+}$regulatory $\mathrm{B}$ lymphocytes, which increases with the activation of $\mathrm{B}$ lymphocytes. Inhibiting $\alpha 7-\mathrm{nAChR}$ with methyllicaconitine inhibits CD40-mediated B lymphocyte proliferation (281). $\alpha 4 \beta 2-\mathrm{nAChR}, \alpha 7-\mathrm{nAChR}$, and $\alpha 9 \alpha 10-\mathrm{nAChR}$ on $\mathrm{B}$ lymphocytes are differentially involved in $\mathrm{B}$ cell-mediated immune cell interactions. $\alpha 7$ and $\alpha 9(\alpha 10)$ subunits of nAChRs are linked to $\mathrm{CD} 40$-mediated $\mathrm{B}$ cell proliferation, while the $\alpha 4 \beta 2-n A C h R$ is linked to $\operatorname{IgM}$ antibody production (151). However, the initial levels of IgM in WT and $\mathrm{M}_{1} / \mathrm{M}_{5}^{-}$ double knockout mice were similar. The OVA-antigen-specific IgG1 levels in $\mathrm{M}_{1} / \mathrm{M}_{5}^{-/-} \mathrm{KO}$ mice were significantly lower, suggesting that $\mathrm{mAChRs}$ are not required for antibody production but are involved in immunoglobulin class switching (282). $\mathrm{M}_{1} \mathrm{mAChR}$ knockout $\left(\mathrm{M}_{1}^{-}{ }^{-}\right)$mice show increased splenic noradrenaline production and a decrease in the number of IgG-producing B cells (283). $\mathrm{M}_{3} \mathrm{mAChR}$ in B cells show an increase in calcium signaling and c-Fos gene expression, thereby affecting several downstream signaling pathways (284). However, an autoantibody against the $\mathrm{M}_{3} \mathrm{mAChR}$ has been reported in the immunopathogenesis of Sjögren's syndrome and correlates with a significant risk of developing B cell lymphoma (285). Together, these studies suggest that AChRs contribute to mounting an effective humoral response. A detailed investigation of cholinergic systems' expression in the different developmental and differentiation stages of B cells needs to be investigated, and its clinical importance in the inflammatory disease yet to be established.

\section{Role in Dendritic Cells (DCs)}

Nicotine impairs the capability of DCs to capture antigens and reduces the responsiveness of DCs to maturation stimuli. The nicotine-treated DCs fail to produce IL-12, IL-1 $\beta$, IL-10, and TNF- $\alpha$ and thus unable to induce APC-dependent T cell responses and Th1-cell polarization. DCs exposed to nicotine tend to polarize $\mathrm{CD} 4^{+} \mathrm{T}$ cells towards the Th2 phenotype. These show increased expression of OX40L and significantly high amounts of IL-4, IL-5, and IL-13 $(261,286)$. CD205 ${ }^{+}$DCs express mRNA encoding secreted lymphocyte antigen-6/ Urokinase-type plasminogen activator receptor-related peptide (SLURP)-1, an endogenous $\alpha 7-\mathrm{nAChR}$ allosteric ligand that stimulates DCs to produce ACh in an autocrine manner (260). Treatment with GTS-21, an $\alpha 7$-AChR agonist, showed a robust anti-inflammatory action during collagen-induced arthritis (CIA) in DBA/1 mice by modulating DCs. GTS-21 treatment down-regulated CD80 and MHC II expression on the surface of DCs, leading to suppression of its infiltrating capacity and differentiation. These inhibitory effects were successfully reversed by the $\alpha 7-\mathrm{nAChR}$ antagonist, methyllycaconitine $(287,288)$. Treatment of DCs with ACh also resulted in the upregulation of the macrophage-derived chemokine (CCL22) in the thymus and the activation-regulated chemokine (CCL17). CCL22 and CCL17 help in the recruitment of Th2 cells at the site of inflammation (289). In both mice and humans, DCs treated with nicotine utilize upregulation of notch ligands and nuclear receptor peroxisome proliferator-activated receptors $\gamma(\operatorname{PPAR} \gamma)$ 
to modulate the Th1/Th2 balance in favor of Th2 lineage (290). Activation of nAChRs on immature DCs (imDCs) has also been shown to have anti-tumorigenic effects. Activation of $\mathrm{nAChR}$ promotes the expression of co-stimulatory molecules CD80/ CD86 and 4-1BBL on imDCs, thereby increasing their ability to stimulate T-cell proliferation. Transfer of nicotine-treated imDCs has been shown to reduce tumor growth by generating an effective cytotoxic $\mathrm{T}$ cell response in the tumor microenvironment (291).

DCs have been found to express the $M_{3} m A C h R, M_{4}$ mAChR, $\mathrm{M}_{5} \mathrm{mAChR}$, ChAT, and AChE (289). Methacholine, a synthetic choline ester, and a non-selective $\mathrm{mAChR}$ agonist were shown to increase expression of the OX40L on DCs, which helps in the interaction co-stimulation with $\mathrm{T}$ cells (255). Cholinergic activation using the $\mathrm{M}_{1} \mathrm{mAChR}$-specific agonist, McN-A-343, in colitis was found to decrease IFN- $\gamma$, IL-17, IL12p70, and IL-23 in the splenic CD11c ${ }^{+}$DCs (181). These studies suggest that AChRs affect the immune response by altering innate immune cells like DCs. Further detailed molecular mechanism of cholinergic receptor signaling in the differentiation and function of DCs under different inflammatory conditions and tissues needs to be investigated.

\section{Role in Macrophages}

The intracellular signaling of alveolar macrophages is mediated by $\alpha 9, \alpha 10$, and $\beta 2$-nAChR. Macrophage populations previously exposed to nicotine show a lower rise in ATP-induced intracellular $\mathrm{Ca}^{2+}$ release, which is independent of STAT3 phosphorylation (292). The $\alpha 7-\mathrm{nAChR}$ on macrophages is vastly sensitive to $\mathrm{ACh}$ released by the $\mathrm{ChAT}^{+} \mathrm{T}$ cells, and its interaction with $\mathrm{ACh}$ leads to reduced production and release of proinflammatory cytokines. Antigen-stimulated spleen cells from $\alpha 7$ knockout mice produce significantly higher amounts of TNF- $\alpha$, IL-6, and IFN- $\gamma$ than splenocytes from WT mice (264). Vagus nerve stimulation (VNS) for a duration of $0.1-60$ s in WT mice modulates cytokine release from macrophages via the $\alpha 7-n A C h R$ receptor. However, the $\alpha 7$ subunit deficiency rendered the VN ineffective in inhibiting TNF- $\alpha$ release (293). Priming macrophages with a cognate ligand for $\alpha 7-n A C h R s$ results in a pharmacological inhibition of $\mathrm{AC}$ which in turn increases the cAMP levels in the cells. Thus, activation of $\alpha 7$ $\mathrm{nAChR}$ in macrophages promotes expression and phosphorylation of c-FOS and CREB, required for a sustained decrease in the endotoxin-induced release of TNF- $\alpha$ (294). In LPS-stimulated human macrophages, ACh-induced activation diminishes pro-inflammatory cytokines like TNF- $\alpha$, IL-1 $\beta$, IL- 6 , and IL-18, but not the anti-inflammatory cytokine, IL-10 (295). VNS causes activation of nAChRs on macrophages, thus hampering their activation via the JAK2-STAT3 signaling pathway. nAChR antagonist treatment of macrophages causes enhanced expression of JAK2 and STAT3, which negatively regulate metalloproteinase 9 (MMP-9) production and inhibit macrophage migration $(296,297)$. It was found that nicotine treatment led to overexpression of IL-1 receptor-associated kinase M (IRAK-M), a negative regulator of TLR4 signaling, via $\alpha 7$-nAChRs. Upregulation of IRAK-M expression is required for the anti-inflammatory effect of nicotine on LPS-induced TNF- $\alpha$ production by peritoneal macrophages (298). In these macrophages, nicotine treatment significantly lowered ATPinduced intracellular $\mathrm{Ca}^{2+}$ signaling via $\beta 2-\mathrm{nAChR}$ only $(299,300)$.

The muscarinic agonist, carbachol, causes a moderate enhancement in phagocytosis of zymosan particles by primary peritoneal macrophages (301). Depending on the local microenvironment, several $\mathrm{mAChR}$ subtypes were reported on differentiated resident macrophages. Activation of $M_{1}-M_{3}$ $\mathrm{mAChR}$ causes tumor macrophages to proliferate mainly by activating the arginase pathway, producing high prostaglandin $\mathrm{E} 2$, and promoting potent angiogenesis. Likewise, in normal macrophages, activation of $\mathrm{M} 1-\mathrm{M}_{2} \mathrm{mAChR}$ - triggers protein kinase $\mathrm{C}$ activity and induces moderate prostaglandin $\mathrm{E}_{2}$ liberation for proliferation (302).

\section{Role in Mast Cells}

Treatment of patients suffering from allergic diseases with nicotine leads to suppressing the production of Th2 cytokines and cysteinyl leukotriene $\mathrm{LTC}_{4}$. Crosslinking of the high-affinity receptor of $\mathrm{IgE}$ on mast cells causes its activation. Upon activation, mast cells at the early phase release preformed inflammatory mediators, and in the late phase, they synthesize and secrete cytokines/chemokines and leukotrienes. Treatment with low concentrations of nicotine leads to suppressing the latephase, but not of the degranulation response. $\alpha 7 / \alpha 9-n A C h R$ antagonists, methyllycaconitine, and alpha-bungarotoxin, successfully reverses nicotine's suppressive effect on the latephase response (303). mAChRs have also been characterized in human mast cells as tissue-based mediators that regulate histamine release and control hypersensitivity $(304,305)$. Upon treatment with nicotine, the human basophil cell line, KU-812, and the human mast cell line, HMC-1, are known to express nAChRs, thereby corroborating ACh expression reports by several cell types outside the neuromuscular system (306).

Atropine, a non-selective $\mathrm{mAChR}$ antagonist, has been shown to reduce the permeability of colon tissue in patients with ulcerative colitis and also further diminish histamine release and disrupt the interactions between mast cells corticotropinreleasing factor (CRF), and eosinophils in the mucosal barrier (307). OXO-M, a stable agonist of $\mathrm{mAChR}$, and physostigmine, an AChE inhibitor, suppress histamine release (308). Methoctramine, an $\mathrm{M}_{2} \mathrm{mAChR}$ antagonist, has been reported to activate phosphoinositide breakdown at high concentrations via pertussis toxin-sensitive $G$ proteins, with subsequent histamine (309). $M_{1}$ mAChR signaling modulates phosphoinositide (PI) 3-kinases, which are critical regulators of mast cell degranulation (310). Mast cell degranulation requires IgE signaling and receptor-mediated calcium mobilization (311). The lethal toxin of Clostridium sordellii is known to inhibit Rac, thereby disrupting calcium turnover and blocking $\mathrm{M}_{1}$-mediated exocytosis in RBL 2H3-hm1 mast cells (312). Together, these studies suggest that AChRs can alter mast cell function and contribute to the pathogenesis of mast cellmediated diseases. 


\section{Role in Neutrophils}

The mRNA and protein expression of several nAChR subunits, such as $\alpha 1, \alpha 3, \alpha 4, \alpha 7, \beta 2$, and $\beta 4$, are also reported in human polymorphonuclear neutrophils (PMN). The $\alpha 7, \alpha 4 \beta 2$, and $\alpha 3 \beta 4$ subunits of $\mathrm{nAChR}$ on PMNs have been shown to have regulatory roles in their maturation at the site of inflammation (313). During inflammation, cell surface adhesion molecules play an integral role in the migration of neutrophils from lymphoid organs to the peripheral inflammatory site. nAChRs are known to regulate the expression of the cell surface protein, CD11b, on the surface of neutrophils. Nicotine administration and VNS significantly reduce surface expression of CD11b on neutrophils via suppression of $\mathrm{F}$-actin polymerization, thereby reducing neutrophil attachment to the endothelium surface and transmigration to inflamed sites caused by microbial infection (314).

In mice, treatment with the non-selective cholinergic antagonist, atropine, led to an increase in the neutrophil population and increased serum corticosterone (CORT) concentrations in treated mice compared to WT mice (315). Neutrophil chemotactic activity is regulated by acetylcholinemediated IL-8 release from epithelial cells via mAChR. ACh significantly stimulates the ERK1/2 and NFkB pathways, leading to an increase in chemotaxis by neutrophils, which can be reversed by tiotropium, an antagonist of the $\mathrm{M}_{3} \mathrm{mAChR}$ (316). The $\mathrm{M}_{3} \mathrm{mAChR}$ takes active participation in triggering cell death and contributes to the pathophysiology observed in several autoimmune diseases like vasculitic inflammation and thrombosis. The stimulation of $\mathrm{M}_{3}$ receptors on neutrophils induces neutrophil extracellular trap formation via the Akt, RAF/MEK/ERK pathway, ROS induction, and peptidyl arginine deiminase activation (317). Blocking the M3 mAChR reduces the proinflammatory effect of ACh on smooth muscles, as well as epithelial and endothelial cells. $\mathrm{M}_{3} \mathrm{mAChR}$ knockout mice show altered neutrophil recruitment due to the downregulation of cell adhesion molecules like fibrinogen- $\alpha$ and CD177 (318). Sputum samples in healthy smokers and chronic obstructive pulmonary disease (COPD) patients have been shown to have increased TGF- $\beta 1$ and ACh concentrations, consequently increasing neutrophil adhesion to epithelial cells. TGF- $\beta 1$ depletion significantly reduces $M_{3} \mathrm{mAChR}$ and ChAT expression on epithelial cells, thereby establishing autocrine/ paracrine feedback during neutrophilic inflammation (319). It is also noticed that during airway hyper-responsiveness due to infections, TNF- $\alpha$ production by neutrophils negatively regulates the $\mathrm{M}_{2} \mathrm{mAChR}$, causing vagally-mediated bronchoconstriction (320).

\section{Role in Natural Killer (NK) Cells}

NK cells play a very important role in several inflammatory and chronic diseases (321). Human NK cells show the complete cholinergic machinery expression, including ChAT, VAChT, AChE, and ChT1 (322). Upon acute inflammation, $\mathrm{ChAT}^{+} \mathrm{NK}$ cells upregulate the synthesis of ACh to stimulate monocytes, modulate cytokine expression in the tissue microenvironment, and reduce inflammatory damages (322). Highly purified NK cells have been reported to express $\alpha 4, \alpha 5, \alpha 6, \beta 2$, and $\beta 3$ subunits of $\mathrm{nAChR}$ receptor (323). Under inflammatory disease conditions, NK cells increase the production of ACh by upregulation of ChAT enzymes. ChAT expression also increases along with the maturation of NK cells. Adoptive transfer of ChAT-expressing $\mathrm{NK}$ cells $\left(\mathrm{ChAT}^{+} \mathrm{NK}\right.$ cells) into the cerebral ventricles of $\mathrm{CX} 3 \mathrm{CR}^{-1-}$ mice reduces inflammation and autoimmune responses in the experimental autoimmune encephalomyelitis (EAE) model (322). $\mathrm{ChAT}^{+} \mathrm{NK}$ cells have been shown to successfully reduce the infiltration of CCR $2^{+}$Ly6C ${ }^{\text {hi }}$ monocytes and lower the secretion of proinflammatory cytokines. The anti-inflammatory effect of NK cells is mediated via $\alpha 7$-nAChRs. NK stimulation with cytokines (IL-12, IL-18, and IL-15) increases the transcription and translation of $\alpha 7-n A C h R$ (322). Activation of $\alpha 7-n A C h R$ in NK cells decreases their NK group 2D member (NKG2D)dependent cell-mediated cytotoxicity and IFN- $\gamma$ production, thereby showing anti-inflammatory properties during inflammation (158). $\beta 2-n A C h R$ modulates NK cell functions via NF-KB-induced transcriptional activity in NK cells (323). Aberrant functioning of $\mathrm{NK}$ cells is the major cause of tumorigenesis and multiple cancers. It has been reported that single nucleotide polymorphisms (SNPs) of mAChR in natural killer cells result in dysregulation of $\mathrm{Ca}^{2+}$ signaling and reduced NK cell cytotoxic activity, leading to the pathophysiology observed in myalgic encephalomyelitis/chronic fatigue syndrome (324). The cytotoxicity of NK cells towards YAC-1 target cells was inhibited by the addition of ACh, suggesting that AChRs on NK cells control the cytotoxic function of NK cells. Furthermore, pilocarpine, an agonist of the mAChR, showed a similar effect on the cytotoxicity of NK cells when atropine was used to block the inhibitory effect of ACh (325). Together, these studies suggest that AChRs can affect the NK cell function in different inflammatory diseases.

\section{Role in Eosinophils}

Human peripheral blood eosinophils express the $M_{3}-M_{5}$ $\mathrm{mAChRs}$, and activation of these mAChRs has an inhibitory effect on the activation of these cells $(307,326)$. Eosinophils play an important role in allergic disorders such as rhinitis, atopic dermatitis, and asthma. In ulcerative colitis, the cholinergic system in eosinophils at the mucosal barrier may contribute to mucosal inflammation (307). However, the role of mAChRs in eosinophils need detailed investigation.

\section{Pre-Clinical and Clinical Importance of the Cholinergic System}

The vagal efferent nerves originate at the medulla and innervate the GI tract, connecting it to the ENS. This gut-brain axis is known to regulate GI motility and secretion via vagal efferent fibers, which form cholinergic synapses in the ENS and respond to inflammatory stimuli (327). Cholinergic transmission between $\mathrm{VN}$ and reticuloendothelial organs is extensively required in maintaining arterial blood pressure, heart rate variability and modulate the innate and adaptive immune response (328). An increased proinflammatory cytokine storm is known to correspond to reduced $\mathrm{VN}$ activity in several inflammatory diseases, including rheumatoid arthritis (RA), systemic lupus 
erythematosus (SLE), sepsis, IBD (329-332). Activating the vagal efferent releases $\mathrm{ACh}$ at the distal end of the $\mathrm{VN}$ and effector ENS, inhibiting the release of proinflammatory cytokines (TNF$\alpha$, IL-1 $\beta$, IL-6, and IL-18), forming the $\operatorname{CAP}(295,333,334)$. The CAP is a highly conserved pathway and plays an important role in controlling morbidity and mortality associated with various human diseases, such as endotoxemia, sepsis, IBD, and RA (293). VNS implants in patients with resistant epilepsy showed LPSinduced release of TNF- $\alpha$, IL- $1 \beta$, and IL- 6 in post-VNS blood. Also, in the RA cohort, patients showed reduced disease severity with reduced TNF- $\alpha$ levels in peripheral blood samples (335, 336).

This pathway can aggressively target innate immune cells and proinflammatory cytokine production. Therefore, it is proposed as a potential therapeutic target for mitigating several infections, including sepsis and the cytokine storm recently reported in SARS-CoV-2 infection $(337,338)$. The neuronal circuits that control TNF- $\beta$ production in macrophages and other innate cells in the spleen lack the enzymatic machinery for ACh production. Rosas-Ballina et al. identified an important connection of the inflammatory reflex by discovering the cholinergic machinery in the memory $\mathrm{CD}^{+}{ }^{+} \mathrm{T}$ cells in the spleen $(259,339)$. Further, this lymphocyte-produced $\mathrm{ACh}$ regulates the innate immune response in the local tissue microenvironment (340). Given the importance of cholinergic signaling in inflammatory reflexes, several drugs and molecules originally designed for neurological diseases draw attention as potential drugs for inflammatory diseases. Some of the drugs that interfere with neuroimmune communication and affect inflammation and immunity are listed in Tables 3 and 4. Further, we discussed the notable cholinergic agents used in humans.

\section{Cholinergic Agonists}

Nicotine acts as a pan-agonist of various homomeric nAChRs including $\alpha 7$-nAChR, $\beta 2$-nAChR, $\alpha 3$-nAChR, $\alpha 4$-nAChR, and $\alpha 5-n A C h R$. However, in epidemiological and clinical trials, nicotine-induced addiction and toxicity leading to several autonomic dysfunctions, cardiovascular malfunctions, tumorigenesis, and neuropathic pain (341-344). Various selective cholinergic agonists are exploited in clinical research to reduce the adverse effects of non-selective receptor activation and cytokine dysregulation in various inflammatory conditions. Some of these selective agonists are discussed below-

\section{GTS-21 [3-(2,4-dimethoxy-benzylidene) anabaseine]}

GTS-21 (also known as DMBX-A) is an orally active small molecule and a selective $\alpha 7-\mathrm{nAChR}$ agonist used in clinical trials for $\mathrm{AD}$ and schizophrenia, shown to enhance memory and cognitive activity (345). GTS-21 is also known to attenuate the production of proinflammatory cytokines TNF- $\alpha$ and IL- $1 \beta$ from monocytes stimulated with Toll-like receptor (TLR) agonists (346). GTS-21 inhibits Akt and NF- $\kappa B$ signaling pathway, thereby reducing the LPS-induced cytokine production in macrophages (347). It has recently been shown that GTS-21 ameliorates polymicrobial sepsis-induced hepatic injury by modulating autophagy (348). GTS-21 is known to inhibit the differentiation of DCs and controls collagen-induced arthritis in mice (287). In human endotoxemia, GTS-21 induces an anti-inflammatory function (349), and higher GTS-21 concentration in the plasma significantly correlated with the lower amount of TNF- $\alpha$, IL-6, and IL-1RA but not IL-10 (349, $350)$. It has been reported that chronic obstructive pulmonary disease (COPD) patients have high levels of IL-6 and nitric oxide (NO), and GTS-21 treatment suppresses the IL-6 and NO levels in plasma by modulating the function of PBMCs (351). In RA patients, GTS-21 suppresses the differentiation of Th1 cells and IFN- $\gamma$ production in PBMCs (352). This drug has also displayed promising results in clinical trials for $\mathrm{AD}$, schizophrenia, ameliorating disease severity in sepsis, pancreatitis, and inflammation induced by traumatic brain injury (353-355).

\section{ABT-126}

The $\alpha 7-n A C h R$ is an extensively studied cholinergic receptor for developing new drugs that will ameliorate cognitive deficiencies, neuropsychiatric disorders, inflammation, and autoimmune diseases. ABT-126 (trade name Neonicline) is a small molecule allosteric modulator of $\alpha 7-\mathrm{nAChR}$. ABT-126 is a safe and welltolerated $\alpha 7-n A C h R$ agonist. A phase II randomized controlled multi-center clinical trial showed a pro-cognitive effect in mild to moderate dementia AD patients (356). Phase II trials with ABT126 also improved schizophrenia-associated cognitive impairment in non-smokers compared to smokers (357). A detailed study on the effect of ABT-21 on different immune parameters is yet to be studied. Given its importance, ABT-126 will be of great value in exploring an effective target for treating critical inflammatory and autoimmune diseases.

\section{CNI-1493}

CNI-1493 (also known as Semapimod) is an anti-amyloidogenic and vagal output stimulant that inhibits systemic inflammation via CAP (358). CNI-1493 was synthesized as an endogenous inhibitor of the synthesis of nitric oxide (NO) and inflammatory cytokines in the CNS $(359,360)$. In the pre-clinical AD model, CNI-1493 has a neuroprotective effect by inhibiting amyloid oligomers' formation and subsequently suppressing the production of IL-6 and TNF- $\alpha$ (361). CNI-1493 has been shown to inhibit LPS-induced TNF- $\alpha$, IL-1 $\alpha$, IL-1, IL-6, and IL-8 in macrophages and monocytes but not in T cells $(362,363)$. In acute bacterial infection, CNI-1493 has been reported to reduce the inflammatory response by inhibiting NO synthesis in macrophages and promoting ROS production in granulocytes (364). In the EAE model, CNI-1493 treatment has been shown to reduce DC maturation and T cell priming (365). CNI-1493 was also found to have a protective effect in clinical trials in gut inflammatory diseases like Crohn's disease and pancreatitis $(366,367)$.

\section{Pilocarpine}

Pilocarpine is a natural alkaloid extracted from the plant Pilocarpus. It acts as a muscarinic agonist and is used to treat the autoimmune Sjogren's syndrome. It stimulates saliva secretion, aqueous tears from lacrimal glands, and mucin from goblet cells $(368,369)$. Pilocarpine hydrochloride has been shown to inhibit Candida albicans biofilm formation and its pathogenicity (370). In the rat model of epilepticus seizure, 
intraperitoneal pilocarpine injection promotes activation of cholinergic neurons and dysregulation of brain homeostasis (371-373). It is known to have no severe side effects in humans as a parasympathomimetic drug (374). Its role in modulating immunological components in infection, cancer, and autoimmunity needs further investigation.

\section{Acetylcholinesterase (AChE) inhibitors}

Inhibitors of acetylcholinesterase (EC 3.1.1.7), such as galantamine, donepezil, huperzine, and rivastigmine, are some of the drugs approved for human use to treat $\mathrm{AD}, \mathrm{MS}$, and dementia (375). Most AChEIs are competitive inhibitors of AChE and allosteric modulators of nAChRs. During inflammation, the increased levels of ACh in the plasma cause these molecules to form a complex with exovesicular AChE, leading to increased nitric oxide efflux from endothelial cells (376). The AChE molecules can terminate activation of the cholinergic anti-inflammatory pathway on red blood cells (RBCs) surface (377). The AChE bound on RBCs' surface can inactivate the plasma ACh and may enhance inflammation (376, 378). AChEI linked to the RBC membrane through a glycosylphosphatidylinositol (GPI) anchor also serves as an age marker for RBCs (377). AChEI modulates the anti-inflammatory pathway and helps in the release of ACh to compensate for the reduced number of AChRs in inflammatory and neurodegenerative diseases. Several AChEIs cross the bloodbrain barrier and inhibit $\mathrm{AChE}$ and $\mathrm{BChE}$ in both the central and peripheral nervous systems. These are listed in Table 3. AChEIs are known to lower proinflammatory cytokines such as IFN- $\gamma$, IL-17, MCP-1, RANTES, TWEAK, and increase antiinflammatory cytokines IL-4 and IL-10 (379).

\section{Cholinergic Antagonists}

Overexpression and altered parasympathetic inputs are often associated with the progression of ovarian, lung, skin cancers, and solid tumors $(380,381)$. Increased $A C h$ signaling via $\mathrm{M}_{1}$ mAChR, $M_{2} \mathrm{mAChR}$, and $\mathrm{M}_{3} \mathrm{mAChR}$ also contributes to asthma and COPD (382). Abnormal cholinergic activity leads to immune-related pathological conditions in several skin diseases like atopic dermatitis, psoriasis, pemphigus, and palmoplantar pustulosis $(19,383,384)$. Aberrant expression of ACh components, namely CHT1, ChAT, VAChT, nAChR, $\mathrm{mAChR}$, and OCT1, and its release in GI tracts contribute to pathological conditions like IBD, colon cancer, and pancreatitis (70, 385, 386). Below, we discussed some of the promising antagonistic agents currently used in humans.

\section{Mecamylamine}

Mecamylamine (also known as inversine) is an orally available, non-selective, and non-competitive antagonist of heteromeric $\alpha 4 \beta 2$ and $\alpha 3 \beta 4$ subtype of $\mathrm{nAChRs}$, and it can cross the bloodbrain barrier even at a low dose (387). It is extensively used as an anti-hypertensive, anti-addictive, and anti-depressant drug (387). Mecamylamine is known to abolish the impairment of macrophages and decrease the Mycobacterium tuberculosis burden induced by nicotine (388). In the presence of IL-18, mecamylamine abolishes the nicotine-induced inhibition of adhesion molecules on monocytes and cytokine production by PBMC (143). The potential for its effectiveness in treating neuroimmune diseases requires further investigation.

\section{Atropine}

It is widely used in treating bradycardia and inhibiting respiratory and oral secretion (389). In vitro treatment with atropine has been shown to reduce the production of IL-2 by concanavalin-A stimulated $\mathrm{T}$ cells and reduced the cytotoxicity of NK cells (390). Along with the suppression of T cell response, it significantly reduces tissue injury, leucocyte accumulation, and inflammatory reactions at the site of turpentine-induced inflammation (180). Atropine administration before LPS challenge in mice has been reported to reduce TNF-alpha and elevated IL-10 levels in the plasma, thus, having a protective role in endotoxic shock (233). Atropine is also shown to lower the IgA production in the small intestine of BALB/c mice (391). Currently, atropine is successfully used to treat myopia, IBD, and MG patients (392-394). However, its role in several neuroimmune and autoimmune diseases needs to be investigated.

\section{Dicyclomine}

Dicyclomine (also known as dicycloverine) is a selective $M_{1}$ $\mathrm{mAChR}$ antagonist having an antispasmodic effect and is effectively used for treating several GI conditions such as irritable bowel syndrome (IBS) and intestinal cramping (395, 396). However, its exact mode of action in controlling mucosal homeostasis remains elusive. Apart from its antimuscarinic activities, it also has anti-fungal properties against the human pathogen Candida albicans. It prevents the growth, adhesion, biofilm formation, and yeast to hyphal transformation in $C$. albicans by targeting gene transduction in both the cAMP pathway and MAPK cascade (397). Dicyclomine hydrochloride is also found to have antibacterial potential in animals challenged with Salmonella typhimurium via competitive inhibition of lipase activity $(398,399)$. The anti-cholinergic implication of dicyclomine on immunological components requires further study.

\section{Tiotropium}

Tiotropium (trade names, Spiriva, Braltus) is a long-acting $\mathrm{M}_{3}$ $\mathrm{mAChR}$ antagonist that has an immunosuppressive function in allergic asthma and chronic obstructive pulmonary disease (COPD) and which improves airway remodeling (400). Tiotropium also reduces the Th2 cytokine production in mice (401), and antagonizes the LTB4 production in human alveolar macrophages (402). In vitro studies have demonstrated that the $\mathrm{M}_{3}$ mAChR expressed on macrophages is responsible for producing pro-inflammatory cytokines like IL- 8 and leukotriene B4 (LTB-4). LTB-4 is an inflammatory mediator that causes leukocyte adhesion, activation, and inflammatory cell recruitments. $\mathrm{M}_{3} \mathrm{mAChR}$ drives neutrophil recruitment via macrophage-derived chemotactic mediators (402). Tiotropium, an $\mathrm{M}_{3} \mathrm{mAChR}$ antagonist, shows anti-chemotactic properties and reduces the ROS-mediated cytotoxicity in alveolar macrophages, thus reducing cellular inflammation $(403,404)$. 


\section{SUMMARY AND FUTURE PERSPECTIVE}

There is growing evidence suggesting bidirectional interactions between the nervous system and the immune system at the cellular and molecular levels. Understanding the multicellular and multidimensional signals involved and the regulatory mechanisms of immunological reflex in chronic and acute inflammatory diseases offer ample opportunity for basic and clinical research. Many neurodegenerative diseases have a close relationship with the activation of inflammation in the central nervous system and the peripheral immune system $(405,406)$. Given the importance of functional circuitry in the secondary lymphoid tissues (407), the cholinergic system's influence on the immune system cannot be ignored while designing therapeutic strategies to treat even neurological disorders. In clinical trials (clinical trial registry numbers NCT00783068, NCT04470479, NCT00000172, NCT00892450), some cholinergic stimulators and pharmaceutical antagonists were used in various inflammatory diseases. These molecules can also alter the innate and adaptive response and need to be investigated further.

Further, the various activation mechanisms of the cholinergic system in different subsets of innate and adaptive immune cells need to be elucidated. A multidimensional and multifactorial systems biology approach could help connect various individual components, such as genetic disposition, cholinergic deficits, inflammatory mechanism, oxidative stress, mitochondrial dysfunction, and other neurotransmitter defects. Such an approach would serve well to understand neuro-immune diseases and may also help in customizing therapeutic regimens. The high degree of homology (64 to 68\% sequence identity and 82 to $92 \%$ sequence similarity) between the

\section{REFERENCES}

1. Karmakar S, Lal G. Role of serotonin receptor signaling in cancer cells and anti-tumor immunity. Theranostics (2021) 11(11):5296-312. doi: 10.7150/ thno.55986

2. Pavlov VA, Tracey KJ. The vagus nerve and the inflammatory reflex-linking immunity and metabolism. Nat Rev Endocrinol (2012) 8(12):743-54. doi: $10.1038 /$ nrendo.2012.189

3. Berthoud HR, Neuhuber WL. Functional and chemical anatomy of the afferent vagal system. Auton Neurosci (2000) 85(1-3):1-17. doi: 10.1016/ S1566-0702(00)00215-0

4. Wessler I, Kirkpatrick CJ. Cholinergic signaling controls immune functions and promotes homeostasis. Int Immunopharmacol (2020) 83:106345. doi: 10.1016/j.intimp.2020.106345

5. Kawashima K, Fujii T. Basic and clinical aspects of non-neuronal acetylcholine: overview of non-neuronal cholinergic systems and their biological significance. J Pharmacol Sci (2008) 106(2):167-73. doi: 10.1254/jphs.fm0070073

6. Dani JA, Bertrand D. Nicotinic acetylcholine receptors and nicotinic cholinergic mechanisms of the central nervous system. Annu Rev Pharmacol Toxicol (2007) 47:699-729. doi: 10.1146/annurev.pharmtox.47.120505.105214

7. Papke RL, Lindstrom JM. Nicotinic acetylcholine receptors: Conventional and unconventional ligands and signaling. Neuropharmacology (2020) 168:108021. doi: 10.1016/j.neuropharm.2020.108021

8. Prado VF, Janickova H, Al-Onaizi MA, Prado MA. Cholinergic circuits in cognitive flexibility. Neuroscience (2017) 345:130-41. doi: 10.1016/ j.neuroscience.2016.09.013 transmembrane domains of mAChRs (250), makes designing small-molecule ligands that could selectively target specific $\mathrm{mAChRs}$ incredibly challenging. Recently, Biased $\mathrm{M}_{1} \mathrm{mAChR}-$ mutant mice were used to develop next-generation drugs for $\mathrm{AD}$, which hold promise for the future (408).

\section{AUTHOR CONTRIBUTIONS}

$\mathrm{NH}$ and GL conceived the idea and wrote the manuscript. All authors contributed to the article and approved the submitted version.

\section{FUNDING}

$\mathrm{NH}$ received the Senior Research Fellowship from the Council of Scientific and Industrial Research. GL received grants from the Department of Biotechnology (Grants numbers, BT/PR15533/ MED/30/1616/2015 and BT/PR14156/BRB/10/1515/2016) and Swarna Jayanti Fellowship (DST/SJF/LSA-01/2017-18) from Department of Science and Technology, Ministry of Science and Technology, Government of India.

\section{ACKNOWLEDGMENTS}

We thank Dr. Jyoti Rao for critical reading, helpful discussion, and editing the manuscript.

9. Sanders LM, Zeisel SH. Choline: Dietary Requirements and Role in Brain Development. Nutr Today (2007) 42(4):181-6. doi: 10.1097/ 01.NT.0000286155.55343.fa

10. Papatriantafyllou M. Neuroimmunology: ChATty B cells. Nat Rev Immunol (2013) 13(2):70. doi: 10.1038/nri3396

11. Wessler I, Kirkpatrick CJ, Racke K. The cholinergic 'pitfall': acetylcholine, a universal cell molecule in biological systems, including humans. Clin Exp Pharmacol Physiol (1999) 26(3):198-205. doi: 10.1046/j.14401681.1999.03016.x

12. Kawashima K, Fujii T. Extraneuronal cholinergic system in lymphocytes. Pharmacol Ther (2000) 86(1):29-48. doi: 10.1016/S0163-7258(99)00071-6

13. Stanaszek PM, Snell JF, O'Neill JJ. Isolation, extraction, and measurement of acetylcholine from Lactobacillus plantarum. Appl Environ Microbiol (1977) 34(2):237-9. doi: 10.1128/AEM.34.2.237-239.1977

14. Reale M, de Angelis F, di Nicola M, Capello E, di Ioia M, Luca G, et al. Relation between pro-inflammatory cytokines and acetylcholine levels in relapsing-remitting multiple sclerosis patients. Int J Mol Sci (2012) 13 (10):12656-64. doi: 10.3390/ijms131012656

15. Lombardo S, Maskos U. Role of the nicotinic acetylcholine receptor in Alzheimer's disease pathology and treatment. Neuropharmacology (2015) 96 (Pt B):255-62. doi: 10.1016/j.neuropharm.2014.11.018

16. Jia JP, Jia JM, Zhou WD, Xu M, Chu CB, Yan X, et al. Differential acetylcholine and choline concentrations in the cerebrospinal fluid of patients with Alzheimer's disease and vascular dementia. Chin Med J (Engl) (2004) 117(8):1161-4.

17. Profita M, Albano GD, Riccobono L, Di Sano C, Montalbano AM, Gagliardo R, et al. Increased levels of Th17 cells are associated with non-neuronal 
acetylcholine in COPD patients. Immunobiology (2014) 219(5):392-401. doi: 10.1016/j.imbio.2014.01.004

18. Apatzidou DA, Iskas A, Konstantinidis A, Alghamdi AM, Tumelty M, Lappin DF, et al. Clinical associations between acetylcholine levels and cholinesterase activity in saliva and gingival crevicular fluid and periodontal diseases. J Clin Periodontol (2018) 45(10):1173-83. doi: 10.1111/jcpe.12989

19. Wessler I, Reinheimer T, Kilbinger H, Bittinger F, Kirkpatrick CJ, Saloga J, et al. Increased acetylcholine levels in skin biopsies of patients with atopic dermatitis. Life Sci (2003) 72(18-19):2169-72. doi: 10.1016/s0024-3205(03) 00079-1

20. Yuan M, Han B, Xia Y, Liu Y, Wang C, Zhang C. Augmentation of peripheral lymphocyte-derived cholinergic activity in patients with acute ischemic stroke. BMC Neurol (2019) 19(1):236. doi: 10.1186/s12883-0191481-5

21. Fujii T, Mashimo M, Moriwaki Y, Misawa H, Ono S, Horiguchi K, et al. Expression and Function of the Cholinergic System in Immune Cells. Front Immunol (2017) 8:1085:1085. doi: 10.3389/fimmu.2017.01085

22. Bellier JP, Kimura H. Peripheral type of choline acetyltransferase: biological and evolutionary implications for novel mechanisms in cholinergic system. J Chem Neuroanat (2011) 42(4):225-35. doi: 10.1016/ j.jchemneu.2011.02.005

23. Oda Y. Choline acetyltransferase: the structure, distribution and pathologic changes in the central nervous system. Pathol Int (1999) 49(11):921-37. doi: 10.1046/j.1440-1827.1999.00977.x

24. Ogawa H, Fujii T, Watanabe Y, Kawashima K. Expression of multiple mRNA species for choline acetyltransferase in human T-lymphocytes. Life Sci (2003) 72(18-19):2127-30. doi: 10.1016/s0024-3205(03)00072-9

25. Misawa H, Matsuura J, Oda Y, Takahashi R, Deguchi T. Human choline acetyltransferase mRNAs with different 5 '-region produce a $69-\mathrm{kDa}$ major translation product. Brain Res Mol Brain Res (1997) 44(2):323-33. doi: 10.1016/s0169-328x(96)00231-8

26. Salamone G, Lombardi G, Gori S, Nahmod K, Jancic C, Amaral MM, et al. Cholinergic modulation of dendritic cell function. J Neuroimmunol (2011) 236(1-2):47-56. doi: 10.1016/j.jneuroim.2011.05.007

27. Koarai A, Traves SL, Fenwick PS, Brown SM, Chana KK, Russell RE, et al. Expression of muscarinic receptors by human macrophages. Eur Respir $J$ (2012) 39(3):698-704. doi: 10.1183/09031936.00136710

28. Cox MA, Duncan GS, Lin GHY, Steinberg BE, Yu LX, Brenner D, et al. Choline acetyltransferase-expressing $\mathrm{T}$ cells are required to control chronic viral infection. Science (6427) 2019) 363:639-44. doi: 10.1126/science. aau9072

29. Tayebati SK, El-Assouad D, Ricci A, Amenta F. Immunochemical and immunocytochemical characterization of cholinergic markers in human peripheral blood lymphocytes. J Neuroimmunol (2002) 132(1-2):147-55. doi: 10.1016/s0165-5728(02)00325-9

30. Milara J, Cervera A, de Diego A, Sanz C, Juan G, Gavaldà A, et al. Nonneuronal cholinergic system contributes to corticosteroid resistance in chronic obstructive pulmonary disease patients. Respir Res (2016) 17 (1):145. doi: 10.1186/s12931-016-0467-8

31. Jönsson $M$, Norrgård $\mathrm{O}$, Forsgren S. Presence of a marked nonneuronal cholinergic system in human colon: study of normal colon and colon in ulcerative colitis. Inflammation Bowel Dis (2007) 13(11):1347-56. doi: 10.1002/ibd.20224

32. Kaufman H, Vadasz C, Lajtha A. Effects of estradiol and dexamethasone on choline acetyltransferase activity in various rat brain regions. Brain Res (1988) 453(1-2):389-92. doi: 10.1016/0006-8993(88)90185-0

33. Luine VN. Estradiol increases choline acetyltransferase activity in specific basal forebrain nuclei and projection areas of female rats. Exp Neurol (1985) 89(2):484-90. doi: 10.1016/0014-4886(85)90108-6

34. Pierdominici M, Maselli A, Colasanti T, Giammarioli AM, Delunardo F, Vacirca D, et al. Estrogen receptor profiles in human peripheral blood lymphocytes. Immunol Lett (2010) 132(1-2):79-85. doi: 10.1016/ j.imlet.2010.06.003

35. Beagley KW, Gockel CM. Regulation of innate and adaptive immunity by the female sex hormones oestradiol and progesterone. FEMS Immunol Med Microbiol (2003) 38(1):13-22. doi: 10.1016/S0928-8244(03)00202-5

36. Schneider AH, Kanashiro A, Dutra SGV, Souza RDN, Veras FP, Cunha FQ, et al. Estradiol replacement therapy regulates innate immune response in ovariectomized arthritic mice. Int Immunopharmacol (2019) 72:504-10. doi: 10.1016/j.intimp.2019.04.048

37. Rothenberger NJ, Somasundaram A, Stabile LP. The Role of the Estrogen Pathway in the Tumor Microenvironment. Int J Mol Sci (2018) 19(2):611. doi: 10.3390/ijms19020611

38. Maglione A, Rolla S, Mercanti SF, Cutrupi S, Clerico M. The Adaptive Immune System in Multiple Sclerosis: An Estrogen-Mediated Point of View. Cells (2019) 8(10):1280. doi: 10.3390/cells8101280

39. Cannon RL, Hoover DB, Baisden RH, Woodruff ML. Effects of trimethyltin (TMT) on choline acetyltransferase activity in the rat hippocampus. Influence of dose and time following exposure. Mol Chem Neuropathol (1994) 23(1):27-45. doi: 10.1007/BF02858505

40. Hioe KM, Jones JM. Effects of trimethyltin on the immune system of rats. Toxicol Lett (1984) 20(3):317-23. doi: 10.1016/0378-4274(84)90166-8

41. Holloway LN, Pannell KH, Whalen MM. Effects of a series of triorganotins on ATP levels in human natural killer cells. Environ Toxicol Pharmacol (2008) 25(1):43-50. doi: 10.1016/j.etap.2007.08.008

42. Röhl C, Grell M, Maser E. The organotin compounds trimethyltin (TMT) and triethyltin (TET) but not tributyltin (TBT) induce activation of microglia co-cultivated with astrocytes. Toxicol In Vitro (2009) 23 (8):1541-7. doi: 10.1016/j.tiv.2009.04.013

43. Seo YS, Ang MJ, Moon BC, Kim HS, Choi G, Lim HS, et al. Protective Effects of. Brain Sci (2019) 9(12):369. doi: 10.3390/brainsci9120369

44. Pompili E, Fabrizi C, Fumagalli L, Fornai F. Autophagy in trimethyltininduced neurodegeneration. J Neural Transm (Vienna) (2020) 127(7):98798. doi: $10.1007 / \mathrm{s} 00702-020-02210-1$

45. Clevers HC, Hoeksema M, Gmelig-Meyling FH, Ballieux RE. Calcium ionophore A23187 induces interleukin 2 reactivity in human $\mathrm{T}$ cells. Scand J Immunol (1985) 22(6):633-8. doi: 10.1111/j.1365-3083. 1985.tb01925.x

46. Peng WB, Sha WH, Li YY, Nie YQ. In vitro anti-tumor effect of cytotoxic T lymphocyte activated by antigen- loaded dendritic cells from peripheral blood mononuclear cells treated with calcium ionophore A23187 and GMCSF. Zhonghua Yi Xue Za Zhi (2010) 90(26):1849-53.

47. Boot JH, Van Hilten JA. The use of the divalent calcium-ionophore A23187 as a biochemical tool in pharmacological and in vitro toxicological studies. Cell Struct Funct (1996) 21(2):97-9. doi: 10.1247/csf.21.97

48. Fujii T, Ushiyama N, Hosonuma K, Suenaga A, Kawashima K. Effects of human antithymocyte globulin on acetylcholine synthesis, its release and choline acetyltransferase transcription in a human leukemic $\mathrm{T}$ cell line. J Neuroimmunol (2002) 128(1-2):1-8. doi: 10.1016/s0165-5728(02) 00111-x

49. Roider T, Katzfuß M, Matos C, Singer K, Renner K, Oefner PJ, et al. Antithymocyte Globulin Induces a Tolerogenic Phenotype in Human Dendritic Cells. Int J Mol Sci (2016) 17(12):2081. doi: 10.3390/ijms17122081

50. Duftner C, Dejaco C, Hengster P, Bijuklic K, Joannidis M, Margreiter R, et al. Apoptotic effects of antilymphocyte globulins on human pro-inflammatory CD4+CD28- T-cells. PloS One (2012) 7(3):e33939. doi: 10.1371/ journal.pone.0033939

51. Gharekhani A, Entezari-Maleki T, Dashti-Khavidaki S, Khalili H. A review on comparing two commonly used rabbit anti-thymocyte globulins as induction therapy in solid organ transplantation. Expert Opin Biol Ther (2013) 13(9):1299-313. doi: 10.1517/14712598.2013.822064

52. Fujii T, Takada-Takatori Y, Kawashima K. Regulatory mechanisms of acetylcholine synthesis and release by T cells. Life Sci (2012) 91(2122):981-5. doi: 10.1016/j.lfs.2012.04.031

53. Jun H, Yu H, Gong J, Jiang J, Qiao X, Perkey E, et al. An immune-beige adipocyte communication via nicotinic acetylcholine receptor signaling. Nat Med (2018) 24(6):814-22. doi: 10.1038/s41591-018-0032-8

54. Cook-Mills JM, Mokyr MB, Cohen RL, Perlman RL, Chambers DA. Neurotransmitter suppression of the in vitro generation of a cytotoxic T lymphocyte response against the syngeneic MOPC-315 plasmacytoma. Cancer Immunol Immunother (1995) 40(2):79-87. doi: 10.1007/BF01520288

55. Gilbert KM, Hoffmann MK. cAMP is an essential signal in the induction of antibody production by B cells but inhibits helper function of $\mathrm{T}$ cells. J Immunol (1985) 135(3):2084-9.

56. Ikeda C, Morita I, Mori A, Fujimoto K, Suzuki T, Kawashima K, et al. Phorbol ester stimulates acetylcholine synthesis in cultured endothelial cells 
isolated from porcine cerebral microvessels. Brain Res (1994) 655(1-2):14752. doi: 10.1016/0006-8993(94)91608-X

57. Chalimoniuk M, King-Pospisil K, Pedersen WA, Malecki A, Wylegala E, Mattson MP, et al. Arachidonic acid increases choline acetyltransferase activity in spinal cord neurons through a protein kinase C-mediated mechanism. J Neurochem (2004) 90(3):629-36. doi: 10.1111/j.14714159.2004.02535.x

58. Kawashima K, Fujii T. Expression of non-neuronal acetylcholine in lymphocytes and its contribution to the regulation of immune function. Front Biosci (2004) 9:2063-85. doi: 10.2741/1390

59. Fujii T, Yamada S, Watanabe $\mathrm{Y}$, Misawa $\mathrm{H}$, Tajima $\mathrm{S}$, Fujimoto K, et al. Induction of choline acetyltransferase mRNA in human mononuclear leukocytes stimulated by phytohemagglutinin, a T-cell activator. J Neuroimmunol (1998) 82(1):101-7. doi: 10.1016/S0165-5728(97)00195-1

60. Graham KL, Zhang JV, Lewén S, Burke TM, Dang T, Zoudilova M, et al. A novel CMKLR1 small molecule antagonist suppresses CNS autoimmune inflammatory disease. PloS One (2014) 9(12):e112925. doi: 10.1371/ journal.pone. 0112925

61. Fujii T, Tsuchiya T, Yamada S, Fujimoto K, Suzuki T, Kasahara T, et al. Localization and synthesis of acetylcholine in human leukemic $\mathrm{T}$ cell lines. J Neurosci Res (1996) 44(1):66-72. doi: 10.1002/(SICI)1097-4547(19960401) 44:1<66::AID-JNR9>3.0.CO;2-G

62. Imai T, Tsuda E, Hozuki T, Yamauchi R, Saitoh M, Hisahara S, et al. Early effect of tacrolimus in improving excitation-contraction coupling in myasthenia gravis. Clin Neurophysiol (2012) 123(9):1886-90. doi: 10.1016/ j.clinph.2012.01.017

63. Sharma K. Cholinesterase inhibitors as Alzheimer's therapeutics (Review). Mol Med Rep (2019) 20(2):1479-87. doi: 10.3892/mmr.2019.10374

64. Darvesh S, Hopkins DA, Geula C. Neurobiology of butyrylcholinesterase. Nat Rev Neurosci (2003) 4(2):131-8. doi: 10.1038/nrn1035

65. Mason HJ. The recovery of plasma cholinesterase and erythrocyte acetylcholinesterase activity in workers after over-exposure to dichlorvos. Occup Med (Lond) (2000) 50(5):343-7. doi: 10.1093/occmed/50.5.343

66. Kasprzak H, Salpeter MM. Recovery of acetylcholinesterase at intact neuromuscular junctions after in vivo inactivation with diisopropylfluorophosphate. J Neurosci (1985) 5(4):951-5. doi: 10.1523/ JNEUROSCI.05-04-00951.1985

67. Grisaru D, Sternfeld M, Eldor A, Glick D, Soreq H. Structural roles of acetylcholinesterase variants in biology and pathology. Eur J Biochem (1999) 264(3):672-86. doi: 10.1046/j.1432-1327.1999.00693.x

68. Szelenyi J, Paldi-Haris P, Hollan S. Changes in the cholinergic system of lymphocytes due to mitogenic stimulation. Immunol Lett (1987) 16(1):4954. doi: 10.1016/0165-2478(87)90060-5

69. Hod K, Sperber AD, Maharshak N, Ron Y, Shapira I, David Z, et al. Serum cholinesterase activity is elevated in female diarrhea-predominant irritable bowel syndrome patients compared to matched controls. Neurogastroenterol Motil (2018) 30(12):e13464. doi: 10.1111/nmo.13464

70. Maharshak N, Shenhar-Tsarfaty S, Aroyo N, Orpaz N, Guberman I, Canaani $\mathrm{J}$, et al. MicroRNA-132 modulates cholinergic signaling and inflammation in human inflammatory bowel disease. Inflammation Bowel Dis (2013) 19 (7):1346-53. doi: 10.1097/MIB.0b013e318281f47d

71. García-Ayllón MS, Millán C, Serra-Basante C, Bataller R, Sáez-Valero J. Readthrough acetylcholinesterase is increased in human liver cirrhosis. PloS One (2012) 7(9):e44598. doi: 10.1371/journal.pone.0044598

72. García-Ayllón MS, Riba-Llena I, Serra-Basante C, Alom J, Boopathy R, SáezValero J. Altered levels of acetylcholinesterase in Alzheimer plasma. PloS One (2010) 5(1):e8701. doi: 10.1371/journal.pone.0008701

73. Darvesh S, Leblanc AM, Macdonald IR, Reid GA, Bhan V, Macaulay RJ, et al. Butyrylcholinesterase activity in multiple sclerosis neuropathology. Chem Biol Interact (2010) 187(1-3):425-31. doi: 10.1016/j.cbi.2010.01.037

74. Brenner T, Hamra-Amitay Y, Evron T, Boneva N, Seidman S, Soreq H. The role of readthrough acetylcholinesterase in the pathophysiology of myasthenia gravis. FASEB J (2003) 17(2):214-22. doi: 10.1096/fj.020609com

75. Rogers SL, Friedhoff LT. The efficacy and safety of donepezil in patients with Alzheimer's disease: results of a US Multicentre, Randomized, Double-Blind, Placebo-Controlled Trial. The Donepezil Study Group. Dementia (1996) 7 (6):293-303. doi: 10.1159/000106895
76. Bar-On P, Millard CB, Harel M, Dvir H, Enz A, Sussman JL, et al. Kinetic and structural studies on the interaction of cholinesterases with the antiAlzheimer drug rivastigmine. Biochemistry (2002) 41(11):3555-64. doi: 10.1021/bi020016x

77. Gowayed MA, Rothe K, Rossol M, Attia AS, Wagner U, Baerwald C, et al. The role of $\alpha 7 \mathrm{nAChR}$ in controlling the anti-inflammatory/anti-arthritic action of galantamine. Biochem Pharmacol (2019) 170:113665. doi: 10.1016/ j.bcp.2019.113665

78. Takata K, Kitamura Y, Saeki M, Terada M, Kagitani S, Kitamura R, et al. Galantamine-induced amyloid-\{beta\} clearance mediated via stimulation of microglial nicotinic acetylcholine receptors. J Biol Chem (2010) 285 (51):40180-91. doi: 10.1074/jbc.M110.142356

79. Ji H, Rabbi MF, Labis B, Pavlov VA, Tracey KJ, Ghia JE. Central cholinergic activation of a vagus nerve-to-spleen circuit alleviates experimental colitis. Mucosal Immunol (2014) 7(2):335-47. doi: 10.1038/mi.2013.52

80. Raskind MA, Peskind ER, Wessel T, Yuan W. Galantamine in AD: A 6month randomized, placebo-controlled trial with a 6-month extension. The Galantamine USA-1 Study Group. Neurology (2000) 54(12):2261-8. doi: $10.1212 / \mathrm{wnl} .54 .12 .2261$

81. Shifrin H, Nadler-Milbauer M, Shoham S, Weinstock M. Rivastigmine alleviates experimentally induced colitis in mice and rats by acting at central and peripheral sites to modulate immune responses. PloS One (2013) 8(2):e57668. doi: 10.1371/journal.pone.0057668

82. Nizri E, Irony-Tur-Sinai M, Faranesh N, Lavon I, Lavi E, Weinstock M, et al. Suppression of neuroinflammation and immunomodulation by the acetylcholinesterase inhibitor rivastigmine. J Neuroimmunol (2008) 203 (1):12-22. doi: 10.1016/j.jneuroim.2008.06.018

83. Emre M, Aarsland D, Albanese A, Byrne EJ, Deuschl G, De Deyn PP, et al. Rivastigmine for dementia associated with Parkinson's disease. N Engl J Med (2004) 351(24):2509-18. doi: 10.1056/NEJMoa041470

84. Rösler M, Anand R, Cicin-Sain A, Gauthier S, Agid Y, Dal-Bianco P, et al. Efficacy and safety of rivastigmine in patients with Alzheimer's disease: international randomised controlled trial. BMJ (1999) 318(7184):633-8. doi: $10.1136 / \mathrm{bmj} .318 .7184 .633$

85. Huang W, Zhu S, Liu X, Huang L, Han Y, Han Q, et al. Cholinergic antiinflammatory pathway involves in the neuroprotective effect of huperzine A on sepsis-associated encephalopathy. Zhonghua Wei Zhong Bing Ji Jiu Yi Xue (2016) 28(5):450-4.

86. Damar U, Gersner R, Johnstone JT, Schachter S, Rotenberg A. Huperzine A as a neuroprotective and antiepileptic drug: a review of preclinical research. Expert Rev Neurother (2016) 16(6):671-80. doi: 10.1080/14737175. 2016.1175303

87. Desilets AR, Gickas JJ, Dunican KC. Role of huperzine a in the treatment of Alzheimer's disease. Ann Pharmacother (2009) 43(3):514-8. doi: 10.1345/ aph.1L402

88. Parthasarathy G, Ravi K, Camilleri M, Andrews C, Szarka LA, Low PA, et al. Effect of neostigmine on gastroduodenal motility in patients with suspected gastrointestinal motility disorders. Neurogastroenterol Motil (2015) 27 (12):1736-46. doi: 10.1111/nmo.12669

89. Frankel A, Gillespie C, Lu CT, Hewett P, Wattchow D. Subcutaneous neostigmine appears safe and effective for acute colonic pseudoobstruction (Ogilvie's syndrome). ANZ J Surg (2019) 89(6):700-5. doi: $10.1111 /$ ans. 15265

90. Valdes-Ferrer SI, Crispin JC, Belaunzaran PF, Cantu-Brito CG, Sierra-Madero J, Alcocer-Varela J. Acetylcholine-esterase inhibitor pyridostigmine decreases $\mathrm{T}$ cell overactivation in patients infected by HIV. AIDS Res Hum Retroviruses (2009) 25(8):749-55. doi: 10.1089/ aid.2008.0257

91. Singh SP, Chand HS, Banerjee S, Agarwal H, Raizada V, Roy S, et al. Acetylcholinesterase Inhibitor Pyridostigmine Bromide Attenuates Gut Pathology and Bacterial Dysbiosis in a Murine Model of Ulcerative Colitis. Dig Dis Sci (2020) 65(1):141-9. doi: 10.1007/s10620019-05838-6

92. Rocha JA, Ribeiro SP, França CM, Coelho O, Alves G, Lacchini S, et al. Increase in cholinergic modulation with pyridostigmine induces antiinflammatory cell recruitment soon after acute myocardial infarction in rats. Am J Physiol Regul Integr Comp Physiol (2016) 310(8):R697-706. doi: 10.1152/ajpregu.00328.2015 
93. Maggi L, Mantegazza R. Treatment of myasthenia gravis: focus on pyridostigmine. Clin Drug Investig (2011) 31(10):691-701. doi: 10.2165/ 11593300-000000000-00000

94. Manini ML, Camilleri M, Grothe R, Di Lorenzo C. Application of Pyridostigmine in Pediatric Gastrointestinal Motility Disorders: A Case Series. Paediatr Drugs (2018) 20(2):173-80. doi: 10.1007/s40272-017-0277-6

95. Kalb A, von Haefen C, Sifringer M, Tegethoff A, Paeschke N, Kostova M, et al. Acetylcholinesterase inhibitors reduce neuroinflammation and -degeneration in the cortex and hippocampus of a surgery stress rat model. PloS One (2013) 8(5):e62679. doi: 10.1371/journal.pone.0062679

96. Arens AM, Kearney T. Adverse Effects of Physostigmine. J Med Toxicol (2019) 15(3):184-91. doi: 10.1007/s13181-019-00697-z

97. Agatonovic-Kustrin S, Kettle C, Morton DW. A molecular approach in drug development for Alzheimer's disease. BioMed Pharmacother (2018) 106:553-65. doi: 10.1016/j.biopha.2018.06.147

98. Matsueda K, Hongo M, Tack J, Aoki H, Saito Y, Kato H. Clinical trial: dosedependent therapeutic efficacy of acotiamide hydrochloride (Z-338) in patients with functional dyspepsia - $100 \mathrm{mg}$ t.i.d. is an optimal dosage. Neurogastroenterol Motil (2010) 22(6):618-e173. doi: 10.1111/j.13652982.2009.01449.x

99. StatPearls. (2021)

100. Maroli A, Di Lascio S, Drufuca L, Cardani S, Setten E, Locati M, et al. Effect of donepezil on the expression and responsiveness to LPS of CHRNA7 and CHRFAM7A in macrophages: A possible link to the cholinergic antiinflammatory pathway. J Neuroimmunol (2019) 332:155-66. doi: 10.1016/ j.jneuroim.2019.04.012

101. Jiang Y, Zou Y, Chen S, Zhu C, Wu A, Liu Y, et al. The anti-inflammatory effect of donepezil on experimental autoimmune encephalomyelitis in C57 BL/6 mice. Neuropharmacology (2013) 73:415-24. doi: 10.1016/ j.neuropharm.2013.06.023

102. Karu TI, Riabykh TP, Sidorova TA, Dobrynin IV. Comparison of blast cell sensitivity to low-intensity laser radiation and chemotherapeutic drugs. Dokl Akad Nauk (1997) 353(1):114-7.

103. Arikawa M, Kakinuma Y, Noguchi T, Todaka H, Sato T. Donepezil, an acetylcholinesterase inhibitor, attenuates LPS-induced inflammatory response in murine macrophage cell line RAW 264.7 through inhibition of nuclear factor kappa B translocation. Eur J Pharmacol (2016) 789:17-26. doi: 10.1016/j.ejphar.2016.06.053

104. Sato T, Enoki Y, Sakamoto Y, Yokota K, Okubo M, Matsumoto M, et al. Donepezil prevents RANK-induced bone loss via inhibition of osteoclast differentiation by downregulating acetylcholinesterase. Heliyon (2015) 1(1): e00013. doi: 10.1016/j.heliyon.2015.e00013

105. Lee JH, Jeong SK, Kim BC, Park KW, Dash A. Donepezil across the spectrum of Alzheimer's disease: dose optimization and clinical relevance. Acta Neurol Scand (2015) 131(5):259-67. doi: 10.1111/ane.12386

106. Tuğal O, Yazici KM, Anil Yağcioğlu AE, Göğüş A. A double-blind, placebo controlled, cross-over trial of adjunctive donepezil for cognitive impairment in schizophrenia. Int J Neuropsychopharmacol (2004) 7(2):117-23. doi: $10.1017 /$ S1461145703004024

107. Muccioli G, Raso GM, Ghe C, Di Carlo R. Effect of L-alpha glycerylphosphorylcholine on muscarinic receptors and membrane microviscosity of aged rat brain. Prog Neuropsychopharmacol Biol Psychiatry (1996) 20(2):323-39. doi: 10.1016/0278-5846(95)00313-4

108. Saegusa Y, Takeda H, Muto S, Oridate N, Nakagawa K, Sadakane C, et al. Decreased motility of the lower esophageal sphincter in a rat model of gastroesophageal reflux disease may be mediated by reductions of serotonin and acetylcholine signaling. Biol Pharm Bull (2011) 34(5):704-11. doi: 10.1248/bpb.34.704

109. Dou Y, Luo J, Wu X, Wei Z, Tong B, Yu J, et al. Curcumin attenuates collagen-induced inflammatory response through the "gut-brain axis". J Neuroinflamm (2018) 15(1):6. doi: 10.1186/s12974-017-1047-7

110. Peeyush Kumar T, Antony S, Soman S, Kuruvilla KP, George N, Paulose CS. Role of curcumin in the prevention of cholinergic mediated cortical dysfunctions in streptozotocin-induced diabetic rats. Mol Cell Endocrinol (2011) 331(1):1-10. doi: 10.1016/j.mce.2010.07.004

111. Okuda T, Haga T, Kanai Y, Endou H, Ishihara T, Katsura I. Identification and characterization of the high-affinity choline transporter. Nat Neurosci (2000) 3(2):120-5. doi: 10.1038/72059
112. Iwao B, Yara M, Hara N, Kawai Y, Yamanaka T, Nishihara H, et al Functional expression of choline transporter like-protein 1 (CTL1) and CTL2 in human brain microvascular endothelial cells. Neurochem Int (2016) 93:40-50. doi: 10.1016/j.neuint.2015.12.011

113. Fujii T, Okuda T, Haga T, Kawashima K. Detection of the high-affinity choline transporter in the MOLT-3 human leukemic T-cell line. Life Sci (2003) 72(18-19):2131-4. doi: 10.1016/S0024-3205(03)00073-0

114. Snider SA, Margison KD, Ghorbani P, LeBlond ND, O’Dwyer C, Nunes JRC, et al. Choline transport links macrophage phospholipid metabolism and inflammation. J Biol Chem (2018) 293(29):11600-11. doi: 10.1074/ jbc.RA118.003180

115. Varoqui H, Erickson JD. Active transport of acetylcholine by the human vesicular acetylcholine transporter. J Biol Chem (1996) 271(44):27229-32. doi: $10.1074 /$ jbc.271.44.27229

116. Weihe E, Tao-Cheng JH, Schäfer MK, Erickson JD, Eiden LE. Visualization of the vesicular acetylcholine transporter in cholinergic nerve terminals and its targeting to a specific population of small synaptic vesicles. Proc Natl Acad Sci USA (1996) 93(8):3547-52. doi: 10.1073/pnas.93.8.3547

117. Hoover DB, Poston MD, Brown S, Lawson SE, Bond CE, Downs AM, et al. Cholinergic leukocytes in sepsis and at the neuroimmune junction in the spleen. Int Immunopharmacol (2020) 81:106359. doi: 10.1016/ j.intimp.2020.106359

118. Wu XQ, Zhao YN, Ding J, Si Z, Cheng DF, Shi HC, et al. Decreased vesicular acetylcholine transporter related to memory deficits in epilepsy: A. Epilepsia (2018) 59(9):1655-66. doi: 10.1111/epi.14533

119. Efange SM, Garland EM, Staley JK, Khare AB, Mash DC. Vesicular acetylcholine transporter density and Alzheimer's disease. Neurobiol Aging (1997) 18(4):407-13. doi: 10.1016/s0197-4580(97)00038-9

120. Leite HR, Oliveira-Lima OC, Pereira LM, Oliveira VEM, Prado VF, Prado MAM, et al. Vesicular acetylcholine transporter knock down-mice are more susceptible to inflammation, c-Fos expression and sickness behavior induced by lipopolysaccharide. Brain Behav Immun (2016) 57:282-92. doi: 10.1016/ j.bbi.2016.05.005

121. Elwary SM, Chavan B, Schallreuter KU. The vesicular acetylcholine transporter is present in melanocytes and keratinocytes in the human epidermis. J Invest Dermatol (2006) 126(8):1879-84. doi: 10.1038/ sj.jid. 5700268

122. Rodriguez-Diaz R, Dando R, Jacques-Silva MC, Fachado A, Molina J, Abdulreda $\mathrm{MH}$, et al. Alpha cells secrete acetylcholine as a non-neuronal paracrine signal priming beta cell function in humans. Nat Med (2011) 17 (7):888-92. doi: 10.1038/nm.2371

123. Sopori ML, Kozak W, Savage SM, Geng Y, Soszynski D, Kluger MJ, et al. Effect of nicotine on the immune system: possible regulation of immune responses by central and peripheral mechanisms. Psychoneuroendocrinology (1998) 23(2):189-204. doi: 10.1016/S0306-4530 (97)00076-0

124. Itier V, Bertrand D. Neuronal nicotinic receptors: from protein structure to function. FEBS Lett (2001) 504(3):118-25. doi: 10.1016/S0014-5793(01) 02702-8

125. Gharpure A, Teng J, Zhuang Y, Noviello CM, Walsh RMJr, Cabuco R, et al. Agonist Selectivity and Ion Permeation in the alpha3beta4 Ganglionic Nicotinic Receptor. Neuron (2019) 104(3):501-11.e6. doi: 10.1016/ j.neuron.2019.07.030

126. Gotti C, Clementi F, Fornari A, Gaimarri A, Guiducci S, Manfredi I, et al. Structural and functional diversity of native brain neuronal nicotinic receptors. Biochem Pharmacol (2009) 78(7):703-11. doi: 10.1016/ j.bcp.2009.05.024

127. Tomizawa M, Maltby D, Talley TT, Durkin KA, Medzihradszky KF, Burlingame AL, et al. Atypical nicotinic agonist bound conformations conferring subtype selectivity. Proc Natl Acad Sci USA (2008) 105 (5):1728-32. doi: 10.1073/pnas.0711724105

128. Beker F, Weber M, Fink RH, Adams DJ. Muscarinic and nicotinic ACh receptor activation differentially mobilize $\mathrm{Ca} 2+$ in rat intracardiac ganglion neurons. J Neurophysiol (2003) 90(3):1956-64. doi: 10.1152/jn.01079.2002

129. Lu B, Kwan K, Levine YA, Olofsson PS, Yang H, Li J, et al. alpha7 nicotinic acetylcholine receptor signaling inhibits inflammasome activation by preventing mitochondrial DNA release. Mol Med (2014) 20:350-8. doi: $10.2119 /$ molmed.2013.00117 
130. Nakane S, Mukaino A, Higuchi O, Watari M, Maeda Y, Yamakawa M, et al. Autoimmune autonomic ganglionopathy: an update on diagnosis and treatment. Expert Rev Neurother (2018) 18(12):953-65. doi: 10.1080/ 14737175.2018.1540304

131. Yamakawa M, Mukaino A, Kimura A, Nagasako Y, Kitazaki Y, Maeda Y, et al. Antibodies to the $\alpha 3$ subunit of the ganglionic-type nicotinic acetylcholine receptors in patients with autoimmune encephalitis. J Neuroimmunol (2020) 349:577399. doi: 10.1016/j.jneuroim.2020.577399

132. Paz ML, Barrantes FJ. Autoimmune Attack of the Neuromuscular Junction in Myasthenia Gravis: Nicotinic Acetylcholine Receptors and Other Targets. ACS Chem Neurosci (2019) 10(5):2186-94. doi: 10.1021/acschemneuro. $9 \mathrm{~b} 00041$

133. Hagforsen E, Edvinsson M, Nordlind K, Michaëlsson G. Expression of nicotinic receptors in the skin of patients with palmoplantar pustulosis. $\mathrm{Br}$ J Dermatol (2002) 146(3):383-91. doi: 10.1046/j.1365-2133.2002.04640.x

134. Abu Zeid O, Abdel-Aziz A, Rashed LA, Said ER. Role of the cutaneous extraneuronal cholinergic system in the pathogenesis of psoriasis: a casecontrol study. Clin Exp Dermatol (2020) 45(4):432-7. doi: 10.1111/ced.14124

135. Westman M, Engström M, Catrina AI, Lampa J. Cell specific synovial expression of nicotinic alpha 7 acetylcholine receptor in rheumatoid arthritis and psoriatic arthritis. Scand J Immunol (2009) 70(2):136-40. doi: 10.1111/j.1365-3083.2009.02266.x

136. Chen J, Cheuk IWY, Shin VY, Kwong A. Acetylcholine receptors: Key players in cancer development. Surg Oncol (2019) 31:46-53. doi: 10.1016/ j.suronc.2019.09.003

137. Shulepko MA, Bychkov ML, Shlepova OV, Shenkarev ZO, Kirpichnikov MP, Lyukmanova EN. Human secreted protein SLURP-1 abolishes nicotineinduced proliferation, PTEN down-regulation and $\alpha 7-\mathrm{nAChR}$ expression up-regulation in lung cancer cells. Int Immunopharmacol (2020) 82:106303. doi: 10.1016/j.intimp.2020.106303

138. Tian G, Lu JY, Hu S, Lü Y, Wang HW, Yang Y. Effect of carbachol on dendritic cell function in the lipopolysaccharides induced murine sepsis model. Zhongguo Wei Zhong Bing Ji Jiu Yi Xue (2006) 18(11):684-6.

139. Zhou L, Jiang ZM, Qiu XM, Zhang YK, Zhang FX, Wang YX. Carbachol alleviates myocardial injury in septic rats through PI3K/AKT signaling pathway. Eur Rev Med Pharmacol Sci (2020) 24(10):5650-8. doi: 10.26355/ eurrev_202005_21356

140. Kanefsky J, Lenburg M, Hai CM. Cholinergic receptor and cyclic stretchmediated inflammatory gene expression in intact ASM. Am J Respir Cell Mol Biol (2006) 34(4):417-25. doi: 10.1165/rcmb.2005-0326OC

141. Duncan G, Collison DJ. Role of the non-neuronal cholinergic system in the eye: a review. Life Sci (2003) 72(18-19):2013-9. doi: 10.1016/s0024-3205(03) 00064-x

142. Zhang S, Petro TM. The effect of nicotine on murine CD4 T cell responses. Int J Immunopharmacol (1996) 18(8-9):467-78. doi: 10.1016/s0192-0561(96) 00054-9

143. Takahashi HK, Iwagaki H, Hamano R, Yoshino T, Tanaka N, Nishibori M. Effect of nicotine on IL-18-initiated immune response in human monocytes. J Leukoc Biol (2006) 80(6):1388-94. doi: 10.1189/jlb.0406236

144. Balfour DJ, Fagerström KO. Pharmacology of nicotine and its therapeutic use in smoking cessation and neurodegenerative disorders. Pharmacol Ther (1996) 72(1):51-81. doi: 10.1016/s0163-7258(96)00099-x

145. Vieyra-Reyes P, Venebra-Muñoz A, Rivas-Santiago B, García-García F. Nicotine as an antidepressant and regulator of sleep in subjects with depression. Rev Neurol (2009) 49(12):661-7. doi: 10.33588/ rn.4912.2009158

146. Matthews JB, Chen FM, Milward MR, Wright HJ, Carter K, McDonagh A, et al. Effect of nicotine, cotinine and cigarette smoke extract on the neutrophil respiratory burst. J Clin Periodontol (2011) 38(3):208-18. doi: 10.1111/j.1600-051X.2010.01676.x

147. Balter M. Firing of toxicologist prompts protest. Science (1994) 264 (5162):1076. doi: 10.1126/science.8178163

148. Donnelly-Roberts DL, Xue IC, Arneric SP, Sullivan JP. In vitro neuroprotective properties of the novel cholinergic channel activator (ChCA), ABT-418. Brain Res (1996) 719(1-2):36-44. doi: 10.1016/00068993(96)00063-7

149. Wilens TE, Biederman J, Spencer TJ, Bostic J, Prince J, Monuteaux MC, et al. A pilot controlled clinical trial of ABT-418, a cholinergic agonist, in the treatment of adults with attention deficit hyperactivity disorder. Am J Psychiatry (1999) 156(12):1931-7. doi: 10.1176/ajp.156.12.1931

150. Potter A, Corwin J, Lang J, Piasecki M, Lenox R, Newhouse PA. Acute effects of the selective cholinergic channel activator (nicotinic agonist) ABT-418 in Alzheimer's disease. Psychopharmacol (Berl) (1999) 142(4):334-42. doi: $10.1007 / \mathrm{s} 002130050897$

151. Koval L, Lykhmus O, Zhmak M, Khruschov A, Tsetlin V, Magrini E, et al. Differential involvement of alpha4beta2, alpha7 and alpha9alpha10 nicotinic acetylcholine receptors in B lymphocyte activation in vitro. Int J Biochem Cell Biol (2011) 43(4):516-24. doi: 10.1016/j.biocel.2010.12.003

152. Mellon RD, Bayer BM. The effects of morphine, nicotine and epibatidine on lymphocyte activity and hypothalamic-pituitary-adrenal axis responses. J Pharmacol Exp Ther (1999) 288(2):635-42.

153. Marshall CG, Ogden DC, Colquhoun D. The actions of suxamethonium (succinyldicholine) as an agonist and channel blocker at the nicotinic receptor of frog muscle. J Physiol (1990) 428:155-74. doi: 10.1113/ jphysiol.1990.sp018205

154. Delogu G, Antonucci A, Moretti S, Marandola M, Tellan G, Signore M, et al. Oxidative stress and mitochondrial glutathione in human lymphocytes exposed to clinically relevant anesthetic drug concentrations. J Clin Anesth (2004) 16(3):189-94. doi: 10.1016/j.jclinane.2003.07.007

155. Sánchez Palacios A, Ortiz Ponce M, Rodríguez Pérez A, Schamann Medina F, García Marrero JA. Modification of mediators of immune reaction after general anaesthesia. Allergol Immunopathol (Madr) (2004) 32(6):352-60. doi: 10.1016/s0301-0546(04)79268-x

156. Shao Z, Li Q, Wang S, Chen Z. Protective effects of PNU-282987 on sepsis -induced acute lung injury in mice. Mol Med Rep (2019) 19(5):3791-8. doi: $10.3892 / \mathrm{mmr} .2019 .10016$

157. Pinheiro NM, Santana FP, Almeida RR, Guerreiro M, Martins MA, Caperuto LC, et al. Acute lung injury is reduced by the $\alpha 7 \mathrm{nAChR}$ agonist PNU-282987 through changes in the macrophage profile. FASEB J (2017) 31(1):320-32. doi: 10.1096/fj.201600431R

158. Zanetti SR, Ziblat A, Torres NI, Zwirner NW, Bouzat C. Expression and Functional Role of alpha7 Nicotinic Receptor in Human Cytokinestimulated Natural Killer (NK) Cells. J Biol Chem (2016) 291(32):1654152. doi: 10.1074/jbc.M115.710574

159. Vicens P, Ribes D, Heredia L, Torrente M, Domingo JL. Motor and anxiety effects of PNU-282987, an alpha7 nicotinic receptor agonist, and stress in an animal model of Alzheimer's disease. Curr Alzheimer Res (2013) 10(5):51623. doi: 10.2174/15672050113109990130

160. Hou Z, Zhou Y, Yang H, Liu Y, Mao X, Qin X, et al. Alpha7 nicotinic acetylcholine receptor activation protects against myocardial reperfusion injury through modulation of autophagy. Biochem Biophys Res Commun (2018) 500(2):357-64. doi: 10.1016/j.bbrc.2018.04.077

161. Sudo RT, Hayashida K, Santos AN, Kawatani M, Monteiro CE, Moreira RD, et al. Novel agonist of alpha4beta2* neuronal nicotinic receptor with antinociceptive efficacy in rodent models of acute and chronic pain. J Pain Res (2018) 11:2453-62. doi: 10.2147/JPR.S169637

162. Liu EYL, Xia Y, Kong X, Guo MSS, Yu AXD, Zheng BZY, et al. Interacting with. Acta Pharm Sin B (2020) 10(10):1926-42. doi: 10.1016/ j.apsb.2020.05.005

163. Xue R, Wan Y, Sun X, Zhang X, Gao W, Wu W. Nicotinic Mitigation of Neuroinflammation and Oxidative Stress After Chronic Sleep Deprivation. Front Immunol (2019) 10:2546. doi: 10.3389/fimmu.2019.02546

164. Krafft PR, Altay O, Rolland WB, Duris K, Lekic T, Tang J, et al. $\alpha 7$ nicotinic acetylcholine receptor agonism confers neuroprotection through GSK-3 $\beta$ inhibition in a mouse model of intracerebral hemorrhage. Stroke (2012) 43 (3):844-50. doi: 10.1161/STROKEAHA.111.639989

165. Sérrière S, Doméné A, Vercouillie J, Mothes C, Bodard S, Rodrigues N, et al. Assessment of the Protection of Dopaminergic Neurons by an $\alpha 7$ Nicotinic Receptor Agonist, PHA 543613 Using [(18)F]LBT-999 in a Parkinson's Disease Rat Model. Front Med (Lausanne) (2015) 2:61. doi: 10.3389/ fmed.2015.00061

166. Bali ZK, Inkeller J, Csurgyók R, Bruszt N, Horváth H, Hernádi I. Differential effects of $\alpha 7$ nicotinic receptor agonist PHA-543613 on spatial memory performance of rats in two distinct pharmacological dementia models. Behav Brain Res (2015) 278:404-10. doi: 10.1016/ j.bbr.2014.10.030 
167. Thomsen MS, Mikkelsen JD. The $\alpha 7$ nicotinic acetylcholine receptor ligands methyllycaconitine, NS6740 and GTS-21 reduce lipopolysaccharide-induced TNF- $\alpha$ release from microglia. J Neuroimmunol (2012) 251(1-2):65-72. doi: 10.1016/j.jneuroim.2012.07.006

168. Bagdas D, Wilkerson JL, Kulkarni A, Toma W, AlSharari S, Gul Z, et al. The $\alpha 7$ nicotinic receptor dual allosteric agonist and positive allosteric modulator GAT107 reverses nociception in mouse models of inflammatory and neuropathic pain. Br J Pharmacol (2016) 173(16):2506-20. doi: 10.1111/ bph. 13528

169. Gauthier AG, Wu J, Lin M, Sitapara R, Kulkarni A, Thakur GA, et al. The Positive Allosteric Modulation of alpha7-Nicotinic Cholinergic Receptors by GAT107 Increases Bacterial Lung Clearance in Hyperoxic Mice by Decreasing Oxidative Stress in Macrophages. Antioxidants (Basel) (2021) 10(1):135. doi: 10.3390/antiox10010135

170. Grandi A, Zini I, Flammini L, Cantoni AM, Vivo V, Ballabeni V, et al. $\alpha 7$ Nicotinic Agonist AR-R17779 Protects Mice against 2,4,6-Trinitrobenzene Sulfonic Acid-Induced Colitis in a Spleen-Dependent Way. Front Pharmacol (2017) 8:809. doi: 10.3389/fphar.2017.00809

171. The FO, Boeckxstaens GE, Snoek SA, Cash JL, Bennink R, Larosa GJ, et al. Activation of the cholinergic anti-inflammatory pathway ameliorates postoperative ileus in mice. Gastroenterology (2007) 133(4):1219-28. doi: 10.1053/j.gastro.2007.07.022

172. van Maanen MA, Lebre MC, van der Poll T, LaRosa GJ, Elbaum D, Vervoordeldonk MJ, et al. Stimulation of nicotinic acetylcholine receptors attenuates collagen-induced arthritis in mice. Arthritis Rheum (2009) 60 (1):114-22. doi: 10.1002/art.24177

173. Lopes F, Graepel R, Reyes JL, Wang A, Petri B, McDougall JJ, et al. Involvement of Mast Cells in $\alpha 7$ Nicotinic Receptor Agonist Exacerbation of Freund's Complete Adjuvant-Induced Monoarthritis in Mice. Arthritis Rheumatol (2016) 68(2):542-52. doi: 10.1002/art.39411

174. Galitovskiy V, Kuruvilla SA, Sevriokov E, Corches A, Pan ML, KalantariDehaghi M, et al. Development of novel approach to diagnostic imaging of lung cancer with. J Cancer Res Ther (Manch) (2013) 1(4):128-37. doi: 10.14312/2052-4994.2013-20

175. Fraser PJ. Pharmacological actions of pure muscarine chloride. $\mathrm{Br} J$ Pharmacol Chemother (1957) 12(1):47-52. doi: 10.1111/j.14765381.1957.tb01361.x

176. Wilson ID, Soltis RD, Olson RE, Erlandsen SL. Cholinergic stimulation of immunoglobulin A secretion in rat intestine. Gastroenterology (1982) 83 (4):881-8. doi: 10.1016/S0016-5085(82)80020-6

177. Yu P, Zhou W, Liu L, Tang YB, Song Y, Lu JJ, et al. L-Satropane Prevents Retinal Neuron Damage by Attenuating Cell Apoptosis and Abeta Production via Activation of M1 Muscarinic Acetylcholine Receptor. Curr Eye Res (2017) 42(9):1319-26. doi: 10.1080/02713683.2017.1315142

178. Fujino H, Kitamura Y, Yada T, Uehara T, Nomura Y. Stimulatory roles of muscarinic acetylcholine receptors on $\mathrm{T}$ cell antigen receptor/CD3 complexmediated interleukin-2 production in human peripheral blood lymphocytes. Mol Pharmacol (1997) 51(6):1007-14. doi: 10.1124/mol.51.6.1007

179. Nomura J, Hosoi T, Okuma Y, Nomura Y. The presence and functions of muscarinic receptors in human T cells: the involvement in IL-2 and IL-2 receptor system. Life Sci (2003) 72(18-19):2121-6. doi: 10.1016/s0024-3205 (03)00071-7

180. Razani-Boroujerdi S, Behl M, Hahn FF, Pena-Philippides JC, Hutt J, Sopori ML. Role of muscarinic receptors in the regulation of immune and inflammatory responses. J Neuroimmunol (2008) 194(1-2):83-8. doi: 10.1016/j.jneuroim.2007.11.019

181. Munyaka P, Rabbi MF, Pavlov VA, Tracey KJ, Khafipour E, Ghia JE. Central muscarinic cholinergic activation alters interaction between splenic dendritic cell and CD4+CD25- T cells in experimental colitis. PloS One (2014) 9(10): e109272. doi: 10.1371/journal.pone.0109272

182. Pavlov VA, Ochani M, Gallowitsch-Puerta M, Ochani K, Huston JM, Czura $\mathrm{CJ}$, et al. Central muscarinic cholinergic regulation of the systemic inflammatory response during endotoxemia. Proc Natl Acad Sci USA (2006) 103(13):5219-23. doi: 10.1073/pnas.0600506103

183. Weber J, Keating GM. Cevimeline. Drugs (2008) 68(12):1691-8. doi: 10.2165/00003495-200868120-00006

184. Renz BW, Tanaka T, Sunagawa M, Takahashi R, Jiang Z, Macchini M, et al. Cholinergic Signaling via Muscarinic Receptors Directly and Indirectly
Suppresses Pancreatic Tumorigenesis and Cancer Stemness. Cancer Discovery (2018) 8(11):1458-73. doi: 10.1158/2159-8290.CD-18-0046

185. McLean LP, Smith A, Cheung L, Sun R, Grinchuk V, Vanuytsel T, et al. Type 3 Muscarinic Receptors Contribute to Clearance of Citrobacter rodentium. Inflammation Bowel Dis (2015) 21(8):1860-71. doi: 10.1097/ MIB. 0000000000000408

186. Ginder PA, Ousley M, Hinthorn D, Liu C, Abdou NI. Hidradenitis suppurativa: evidence for a bactericidal defect correctable by cholinergic agonist in vitro and in vivo. J Clin Immunol (1982) 2(3):237-41. doi: 10.1007/BF00915227

187. Cosyns SM, Shiva S, Lefebvre RA. Protective effect of exogenous nitrite in postoperative ileus. Br J Pharmacol (2015) 172(20):4864-74. doi: 10.1111/ bph. 13255

188. Greco FA, Simms NJ, Athappilly GK. Bethanechol as a Corrective for Urinary Retention Associated With Olanzapine Administration. Prim Care Companion CNS Disord (2019) 21(5):19102429. doi: 10.4088/ PCC. 19102429

189. Cristofaro I, Limongi C, Piscopo P, Crestini A, Guerriero C, Fiore M, et al. M2 Receptor Activation Counteracts the Glioblastoma Cancer Stem Cell Response to Hypoxia Condition. Int J Mol Sci (2020) 21(5):1700. doi: 10.3390/ijms21051700

190. Park HY, Park C, Hwang HJ, Kim BW, Kim GY, Kim CM, et al. 7,8Dihydroxyflavone attenuates the release of pro-inflammatory mediators and cytokines in lipopolysaccharide-stimulated BV2 microglial cells through the suppression of the NF- $\mathrm{KB}$ and MAPK signaling pathways. Int J Mol Med (2014) 33(4):1027-34. doi: 10.3892/ijmm.2014.1652

191. Park HY, Kim GY, Hyun JW, Hwang HJ, Kim ND, Kim BW, et al. 7,8Dihydroxyflavone exhibits anti-inflammatory properties by downregulating the NF- $\mathrm{KB}$ and MAPK signaling pathways in lipopolysaccharide-treated RAW264.7 cells. Int J Mol Med (2012) 29(6):1146-52. doi: 10.3892/ ijmm.2012.935

192. Chen C, Wang Z, Zhang Z, Liu X, Kang SS, Zhang Y, et al. The prodrug of 7,8-dihydroxyflavone development and therapeutic efficacy for treating Alzheimer's disease. Proc Natl Acad Sci USA (2018) 115(3):578-83. doi: 10.1073/pnas.1718683115

193. Yang YJ, Li YK, Wang W, Wan JG, Yu B, Wang MZ, et al. Small-molecule TrkB agonist 7,8-dihydroxyflavone reverses cognitive and synaptic plasticity deficits in a rat model of schizophrenia. Pharmacol Biochem Behav (2014) 122:30-6. doi: 10.1016/j.pbb.2014.03.013

194. Jayasuriya GM, Elmslie G, Burstein ES, Ellis J. Dronedarone Modulates M1 and M3 Muscarinic Receptors with Subtype Selectivity, Functional Selectivity, and Probe Dependence. Pharmacology (2017) 99(3-4):128-38. doi: $10.1159 / 000453362$

195. Stahl E, Ellis J. Novel allosteric effects of amiodarone at the muscarinic M5 receptor. J Pharmacol Exp Ther (2010) 334(1):214-22. doi: 10.1124/ jpet.109.165316

196. Nakajima K, Yamazaki K, Yamada E, Kanaji Y, Kosaka S, Sato K, et al. Amiodarone stimulates interleukin- 6 production in cultured human thyrocytes, exerting cytotoxic effects on thyroid follicles in suspension culture. Thyroid (2001) 11(2):101-9. doi: 10.1089/105072501300042703

197. Fogoros RN. Major clinical trials assessing the prophylactic use of amiodarone in patients with ventricular tachyarrhythmias. Control Clin Trials (1996) 17(3 Suppl):37S-46S. doi: 10.1016/s0197-2456(96)00017-7

198. Naccarelli GV, Wolbrette DL, Dell'Orfano JT, Patel HM, Luck JC. Amiodarone: what have we learned from clinical trials? Clin Cardiol (2000) 23(2):73-82. doi: 10.1002/clc.4960230203

199. Rosas-Ballina M, Valdés-Ferrer SI, Dancho ME, Ochani M, Katz D, Cheng $\mathrm{KF}$, et al. Xanomeline suppresses excessive pro-inflammatory cytokine responses through neural signal-mediated pathways and improves survival in lethal inflammation. Brain Behav Immun (2015) 44:19-27. doi: 10.1016/ j.bbi.2014.07.010

200. Shekhar A, Potter WZ, Lightfoot J, Lienemann J, Dubé S, Mallinckrodt C, et al. Selective muscarinic receptor agonist xanomeline as a novel treatment approach for schizophrenia. Am J Psychiatry (2008) 165(8):1033-9. doi: 10.1176/appi.ajp.2008.06091591

201. Mirza NR, Peters D, Sparks RG. Xanomeline and the antipsychotic potential of muscarinic receptor subtype selective agonists. CNS Drug Rev (2003) 9 (2):159-86. doi: 10.1111/j.1527-3458.2003.tb00247.x 
202. Stelmach JE, Liu L, Patel SB, Pivnichny JV, Scapin G, Singh S, et al. Design and synthesis of potent, orally bioavailable dihydroquinazolinone inhibitors of p38 MAP kinase. Bioorg Med Chem Lett (2003) 13(2):277-80. doi: $10.1016 / \mathrm{s} 0960-894 \mathrm{x}(02) 00752-7$

203. Chen ML, Tsai TC, Wang LK, Lin YY, Tsai YM, Lee MC, et al. Clozapine inhibits Th1 cell differentiation and causes the suppression of IFN- $\gamma$ production in peripheral blood mononuclear cells. Immunopharmacol Immunotoxicol (2012) 34(4):686-94. doi: 10.3109/08923973.2011.651535

204. Chen ML, Wu S, Tsai TC, Wang LK, Tsai FM. Regulation of macrophage immune responses by antipsychotic drugs. Immunopharmacol Immunotoxicol (2013) 35(5):573-80. doi: 10.3109/08923973.2013.828744

205. Chen ML, Wu S, Tsai TC, Wang LK, Tsai FM. Regulation of neutrophil phagocytosis of Escherichia coli by antipsychotic drugs. Int Immunopharmacol (2014) 23(2):550-7. doi: 10.1016/j.intimp.2014.09.030

206. Leucht S, Cipriani A, Spineli L, Mavridis D, Orey D, Richter F, et al. Comparative efficacy and tolerability of 15 antipsychotic drugs in schizophrenia: a multiple-treatments meta-analysis. Lancet (2013) 382 (9896):951-62. doi: 10.1016/S0140-6736(13)60733-3

207. Kanashiro A, Talbot J, Peres RS, Pinto LG, Bassi GS, Cunha TM, et al. Neutrophil Recruitment and Articular Hyperalgesia in AntigenInduced Arthritis are Modulated by the Cholinergic Anti-Inflammatory Pathway. Basic Clin Pharmacol Toxicol (2016) 119(5):453-7. doi: 10.1111/ bcpt.12611

208. Pothoulakis C, Castagliuolo I, Leeman SE. Neuroimmune mechanisms of intestinal responses to stress. Role of corticotropin-releasing factor and neurotensin. Ann N Y Acad Sci (1998) 840:635-48. doi: 10.1111/j.17496632.1998.tb09602.x

209. Young HS, Herbette LG, Skita V. Alpha-bungarotoxin binding to acetylcholine receptor membranes studied by low angle X-ray diffraction. Biophys J (2003) 85(2):943-53. doi: 10.1016/S0006-3495(03)74533-0

210. De Rosa MJ, Dionisio L, Agriello E, Bouzat C. Esandi MeC. Alpha 7 nicotinic acetylcholine receptor modulates lymphocyte activation. Life Sci (2009) 85 (11-12):444-9. doi: 10.1016/j.lfs.2009.07.010

211. McMahon LR. Green tobacco sickness: mecamylamine, varenicline, and nicotine vaccine as clinical research tools and potential therapeutics. Expert Rev Clin Pharmacol (2019) 12(3):189-95. doi: 10.1080/17512433. 2019.1570844

212. Damaj MI, Flood P, Ho KK, May EL, Martin BR. Effect of dextrometorphan and dextrorphan on nicotine and neuronal nicotinic receptors: in vitro and in vivo selectivity. J Pharmacol Exp Ther (2005) 312(2):780-5. doi: 10.1124/ jpet.104.075093

213. Stahl SM. Dextromethorphan/Bupropion: A Novel Oral NMDA (N-methyld-aspartate) Receptor Antagonist with Multimodal Activity. CNS Spectr (2019) 24(5):461-6. doi: 10.1017/S1092852919001470

214. Chen DY, Song PS, Hong JS, Chu CL, Pan IH, Chen YM, et al. Dextromethorphan inhibits activations and functions in dendritic cells. Clin Dev Immunol (2013) 2013:125643. doi: 10.1155/2013/125643

215. Werling LL, Lauterbach EC, Calef U. Dextromethorphan as a potential neuroprotective agent with unique mechanisms of action. Neurologist (2007) 13(5):272-93. doi: 10.1097/NRL.0b013e3180f60bd8

216. Zhang W, Wang T, Qin L, Gao HM, Wilson B, Ali SF, et al. Neuroprotective effect of dextromethorphan in the MPTP Parkinson's disease model: role of NADPH oxidase. FASEB J (2004) 18(3):589-91. doi: 10.1096/fj.03-0983fje

217. Chechneva OV, Mayrhofer F, Daugherty DJ, Pleasure DE, Hong JS, Deng W. Low dose dextromethorphan attenuates moderate experimental autoimmune encephalomyelitis by inhibiting NOX2 and reducing peripheral immune cells infiltration in the spinal cord. Neurobiol Dis (2011) 44(1):63-72. doi: 10.1016/j.nbd.2011.06.004

218. Chen DY, Lin CC, Chen YM, Chao YH, Yang DH. Dextromethorphan Exhibits Anti-inflammatory and Immunomodulatory Effects in a Murine Model of Collagen-Induced Arthritis and in Human Rheumatoid Arthritis. Sci Rep (2017) 7(1):11353. doi: 10.1038/s41598-017-11378-8

219. Cummings JL, Lyketsos CG, Peskind ER, Porsteinsson AP, Mintzer JE, Scharre DW, et al. Effect of Dextromethorphan-Quinidine on Agitation in Patients With Alzheimer Disease Dementia: A Randomized Clinical Trial. JAMA (2015) 314(12):1242-54. doi: 10.1001/jama.2015.10214

220. Gredal O, Werdelin L, Bak S, Christensen PB, Boysen G, Kristensen MO, et al. A clinical trial of dextromethorphan in amyotrophic lateral sclerosis.
Acta Neurol Scand (1997) 96(1):8-13. doi: 10.1111/j.1600-0404. 1997.tb00231.x

221. De-Pu Z, Li-Sha G, Guang-Yi C, Xiaohong G, Chao X, Cheng Z, et al. The cholinergic anti-inflammatory pathway ameliorates acute viral myocarditis in mice by regulating CD4. Virulence (2018) 9(1):1364-76. doi: 10.1080/ 21505594.2018.1482179

222. Kamens HM, Peck C, Garrity C, Gechlik A, Jenkins BC, Rajan A. alpha6beta2 nicotinic acetylcholine receptors influence locomotor activity and ethanol consumption. Alcohol (2017) 61:43-9. doi: 10.1016/ j.alcohol.2017.02.178

223. Beckmann JS, Meyer AC, Pivavarchyk M, Horton DB, Zheng G, Smith AM, et al. r-bPiDI, an $\alpha 6 \beta 2^{*}$ Nicotinic Receptor Antagonist, Decreases NicotineEvoked Dopamine Release and Nicotine Reinforcement. Neurochem Res (2015) 40(10):2121-30. doi: 10.1007/s11064-015-1680-4

224. Cuny H, Yu R, Tae HS, Kompella SN, Adams DJ. alpha-Conotoxins active at alpha3-containing nicotinic acetylcholine receptors and their molecular determinants for selective inhibition. Br J Pharmacol (2018) 175(11):185568. doi: $10.1111 / \mathrm{bph} .13852$

225. Zazueta-Favela D, Donis-Maturano L, Licea-Navarro AF, Bernáldez-Sarabia J, Dan KWL, Cota-Arce JM, et al. Marine peptides as immunomodulators. Immunopharmacol Immunotoxicol (2019) 41(4):463-8. doi: 10.1080/ 08923973.2019.1641114

226. Padilla A, Keating P, Hartmann JX, Marí F. Effects of $\alpha$-conotoxin ImI on TNF- $\alpha$, IL- 8 and TGF- $\beta$ expression by human macrophage-like cells derived from THP-1 pre-monocytic leukemic cells. Sci Rep (2017) 7(1):12742. doi: 10.1038/s41598-017-11586-2

227. Gundisch D, Eibl C. Nicotinic acetylcholine receptor ligands, a patent review (2006-2011). Expert Opin Ther Pat (2011) 21(12):1867-96. doi: 10.1517/ 13543776.2011.637919

228. Zaveri N, Jiang F, Olsen C, Polgar W, Toll L. Novel $\alpha 3 \beta 4$ nicotinic acetylcholine receptor-selective ligands. Discovery, structure-activity studies, and pharmacological evaluation. J Med Chem (2010) 53(22):818791. doi: $10.1021 / \mathrm{jm} 1006148$

229. Maisonneuve IM, Glick SD. Anti-addictive actions of an iboga alkaloid congener: a novel mechanism for a novel treatment. Pharmacol Biochem Behav (2003) 75(3):607-18. doi: 10.1016/s0091-3057 (03)00119-9

230. Toll L, Zaveri NT, Polgar WE, Jiang F, Khroyan TV, Zhou W, et al. AT-1001: a high affinity and selective alpha3beta4 nicotinic acetylcholine receptor antagonist blocks nicotine self-administration in rats. Neuropsychopharmacology (2012) 37(6):1367-76. doi: 10.1038/npp.2011.322

231. Leffler DA, Kelly CP, Abdallah HZ, Colatrella AM, Harris LA, Leon F, et al. A randomized, double-blind study of larazotide acetate to prevent the activation of celiac disease during gluten challenge. Am J Gastroenterol (2012) 107(10):1554-62. doi: 10.1038/ajg.2012.211

232. Brown KC, Lau JK, Dom AM, Witte TR, Luo H, Crabtree CM, et al. MG624, an alpha7-nAChR antagonist, inhibits angiogenesis via the Egr-1/FGF2 pathway. Angiogenesis (2012) 15(1):99-114. doi: 10.1007/s10456-011-9246-9

233. Fuentes JM, Fulton WB, Nino D, Talamini MA, Maio AD. Atropine treatment modifies LPS-induced inflammatory response and increases survival. Inflammation Res (2008) 57(3):111-7. doi: 10.1007/s00011-0077134-y

234. McDermott SW, Altekruse JM. Dynamic model for preventing mental retardation in the population: the importance of poverty and deprivation. Res Dev Disabil (1994) 15(1):49-65. doi: 10.1016/0891-4222 (94) $90038-8$

235. Qiu YH, Peng YP, Zhang QQ, Wang JH. [Effect of acetylcholine on the proliferation of T lymphocyte of rat spleen]. Sheng Li Xue Bao (1995) 47 (3):275-80.

236. Wu XJ, Liu HM, Song XM, Zhao B, Leng Y, Wang EY, et al. Penehyclidine hydrochloride inhibits TLR4 signaling and inflammation, and attenuates blunt chest trauma and hemorrhagic shock-induced acute lung injury in rats. Mol Med Rep (2018) 17(5):6327-36. doi: 10.3892/mmr.2018.8644

237. Bhattacharjee A, Chaudhuri R, Dash JJ, Saha M, Choudhury L, Roy S. Pretreatment with Scopolamine Naturally Suppresses Japanese Encephalitis Viral Load in Embryonated Chick Through Regulation of Multiple Signaling Pathways. Appl Biochem Biotechnol (2021). doi: 10.1007/s12010021-03526-8 
238. Pitcher JD, De Paiva CS, Pelegrino FS, McClellan AJ, Raince JK, Pangelinan SB, et al. Pharmacological cholinergic blockade stimulates inflammatory cytokine production and lymphocytic infiltration in the mouse lacrimal gland. Invest Ophthalmol Vis Sci (2011) 52(6):3221-7. doi: 10.1167/iovs.094212

239. Spinks A, Wasiak J. Scopolamine (hyoscine) for preventing and treating motion sickness. Cochrane Database Syst Rev (2011) 6:CD002851. doi: 10.1002/14651858.CD002851.pub4

240. Ripamonti C, Mercadante S, Groff L, Zecca E, De Conno F, Casuccio A. Role of octreotide, scopolamine butylbromide, and hydration in symptom control of patients with inoperable bowel obstruction and nasogastric tubes: a prospective randomized trial. J Pain Symptom Manage (2000) 19(1):23-34. doi: 10.1016/s0885-3924(99)00147-5

241. Smith PM, Troughton AH, Gleeson F, Walters J, McCarthy CF. Pirenzepine in non-ulcer dyspepsia: a double-blind multicentre trial. J Int Med Res (1990) 18(1):16-20. doi: 10.1177/030006059001800103

242. Morelli A, Pelli A, Narducci F, Spadacini A. Pirenzepine in the treatment of gastric ulcer. A double-blind short-term clinical trial. Scand J Gastroenterol Suppl (1979) 57:51-5.

243. Miao Y, Bi XY, Zhao M, Jiang HK, Liu JJ, Li DL, et al. Acetylcholine inhibits tumor necrosis factor $\alpha$ activated endoplasmic reticulum apoptotic pathway via EGFR-PI3K signaling in cardiomyocytes. J Cell Physiol (2015) 230 (4):767-74. doi: $10.1002 /$ jcp. 24800

244. Croom KF, Keating GM. Darifenacin: in the treatment of overactive bladder. Drugs Aging (2004) 21(13):885-92. doi: 10.2165/00002512-20042113000005 discussion 93-4.

245. Mashimo M, Fujii M, Sakagawa N, Fukuda Y, Imanaka R, Fujii T. Muscarinic Acetylcholine Receptors Modulate Interleukin-6 Production and Immunoglobulin Class Switching in Daudi Cells. Biol Pharm Bull (2020) 43(12):1950-3. doi: 10.1248/bpb.b20-00461

246. Xu ZP, Song Y, Yang K, Zhou W, Hou LN, Zhu L, et al. M3 mAChRmediated IL-8 expression through PKC/NF- $\mathrm{KB}$ signaling pathways. Inflammation Res (2014) 63(6):463-73. doi: 10.1007/s00011-014-0718-4

247. Yazdani N, Sadeghi R, Momeni-Moghaddam H, Zarifmahmoudi L, Ehsaei A. Comparison of cyclopentolate versus tropicamide cycloplegia: A systematic review and meta-analysis. J Optom (2018) 11(3):135-43. doi: 10.1016/j.optom.2017.09.001

248. Caulfield MP, Birdsall NJ. International Union of Pharmacology. XVII. Classification of muscarinic acetylcholine receptors. Pharmacol Rev (1998) 50(2):279-90.

249. Hulme EC, Birdsall NJ, Buckley NJ. Muscarinic receptor subtypes. Annu Rev Pharmacol Toxicol (1990) 30:633-73. doi: 10.1146/annurev.pa. 30.040190 .003221

250. Maeda S, Qu Q, Robertson MJ, Skiniotis G, Kobilka BK. Structures of the M1 and M2 muscarinic acetylcholine receptor/G-protein complexes. Science (6440) 2019) 364:552-7. doi: 10.1126/science.aaw5188

251. Lehner KR, Silverman HA, Addorisio ME, Roy A, Al-Onaizi MA, Levine Y, et al. Forebrain Cholinergic Signaling Regulates Innate Immune Responses and Inflammation. Front Immunol (2019) 10:585. doi: 10.3389/ fimmu.2019.00585

252. Lee BH, Gauna AE, Perez G, Park YJ, Pauley KM, Kawai T, et al. Autoantibodies against muscarinic type 3 receptor in Sjögren's syndrome inhibit aquaporin 5 trafficking. PloS One (2013) 8(1):e53113. doi: 10.1371/ journal.pone. 0053113

253. Scherbaum I, Heidecke H, Bunte K, Peters U, Beikler T, Boege F. Autoantibodies against M. Aging (Albany NY) (2020) 12(16):16609-20. doi: 10.18632/aging.103864

254. Loebel M, Grabowski P, Heidecke H, Bauer S, Hanitsch LG, Wittke K, et al. Antibodies to $\beta$ adrenergic and muscarinic cholinergic receptors in patients with Chronic Fatigue Syndrome. Brain Behav Immun (2016) 52:32-9. doi: 10.1016/j.bbi.2015.09.013

255. Liu T, Xie C, Chen X, Zhao F, Liu AM, Cho DB, et al. Role of muscarinic receptor activation in regulating immune cell activity in nasal mucosa. Allergy (2010) 65(8):969-77. doi: 10.1111/j.1398-9995.2009.02281.x

256. Sethi A, Kulkarni N, Sonar S, Lal G. Role of miRNAs in CD4 T cell plasticity during inflammation and tolerance. Front Genet (2013) 4:8. doi: 10.3389/ fgene. 2013.00008
257. Kulkarni N, Sonar SA, Lal G. Plasticity of Th17 and Tregs and its clinical importance as therapeutic target in inflammatory bowel disease. Indian J Inflammation Res (2018) 1(1):R2. doi: 10.15305/ijir/vli1/258

258. Willemze RA, Brinkman DJ, Welting O, van Hamersveld PHP, Verseijden C, Luyer MD, et al. Acetylcholine-producing T cells augment innate immunedriven colitis but are redundant in T cell-driven colitis. Am J Physiol Gastrointest Liver Physiol (2019) 317(5):G557-G68. doi: 10.1152/ ajpgi.00067.2019

259. Rosas-Ballina M, Olofsson PS, Ochani M, Valdes-Ferrer SI, Levine YA, Reardon C, et al. Acetylcholine-synthesizing T cells relay neural signals in a vagus nerve circuit. Science (2011) 334(6052):98-101. doi: 10.1126/ science. 1209985

260. Fujii T, Horiguchi K, Sunaga H, Moriwaki Y, Misawa H, Kasahara T, et al. SLURP-1, an endogenous alpha7 nicotinic acetylcholine receptor allosteric ligand, is expressed in CD205(+) dendritic cells in human tonsils and potentiates lymphocytic cholinergic activity. J Neuroimmunol (2014) 267 (1-2):43-9. doi: 10.1016/j.jneuroim.2013.12.003

261. Nouri-Shirazi M, Guinet E. Evidence for the immunosuppressive role of nicotine on human dendritic cell functions. Immunology (2003) 109(3):36573. doi: 10.1046/j.1365-2567.2003.01655.x

262. Hernandez CP, Morrow K, Velasco C, Wyczechowska DD, Naura AS, Rodriguez PC. Effects of cigarette smoke extract on primary activated T cells. Cell Immunol (2013) 282(1):38-43. doi: 10.1016/j.cellimm.2013.04.005

263. Geng Y, Savage SM, Razani-Boroujerdi S, Sopori ML. Effects of nicotine on the immune response. II. Chronic nicotine treatment induces T cell anergy. J Immunol (1996) 156(7):2384-90.

264. Fujii YX, Fujigaya H, Moriwaki Y, Misawa H, Kasahara T, Grando SA, et al. Enhanced serum antigen-specific IgG1 and proinflammatory cytokine production in nicotinic acetylcholine receptor alpha7 subunit gene knockout mice. J Neuroimmunol (2007) 189(1-2):69-74. doi: 10.1016/ j.jneuroim.2007.07.003

265. Oloris SC, Frazer-Abel AA, Jubala CM, Fosmire SP, Helm KM, Robinson SR, et al. Nicotine-mediated signals modulate cell death and survival of $\mathrm{T}$ lymphocytes. Toxicol Appl Pharmacol (2010) 242(3):299-309. doi: 10.1016/ j.taap.2009.10.020

266. Mashimo M, Komori M, Matsui YY, Murase MX, Fujii T, Takeshima S, et al. Distinct Roles of alpha7 nAChRs in Antigen-Presenting Cells and CD4(+) T Cells in the Regulation of T Cell Differentiation. Front Immunol (2019) 10:1102. doi: 10.3389/fimmu.2019.01102

267. Zdanowski R, Krzyzowska M, Ujazdowska D, Lewicka A, Lewicki S. Role of alpha7 nicotinic receptor in the immune system and intracellular signaling pathways. Cent Eur J Immunol (2015) 40(3):373-9. doi: 10.5114/ ceji.2015.54602

268. De Rosa MJ, Dionisio L, Agriello E, Bouzat C, Esandi Mdel C. Alpha 7 nicotinic acetylcholine receptor modulates lymphocyte activation. Life Sci (2009) 85(11-12):444-9. doi: 10.1016/j.lfs.2009.07.010

269. Nizri E, Irony-Tur-Sinai M, Lory O, Orr-Urtreger A, Lavi E, Brenner T. Activation of the cholinergic anti-inflammatory system by nicotine attenuates neuroinflammation via suppression of Th1 and Th17 responses. J Immunol (2009) 183(10):6681-8. doi: 10.4049/jimmunol.0902212

270. Liu Z, Han B, Li P, Wang Z, Fan Q. Activation of alpha7nAChR by nicotine reduced the Th17 response in CD4(+)T lymphocytes. Immunol Invest (2014) 43(7):667-74. doi: 10.3109/08820139.2014.914532

271. Wang DW, Zhou RB, Yao YM, Zhu XM, Yin YM, Zhao GJ, et al. Stimulation of $\alpha 7$ nicotinic acetylcholine receptor by nicotine increases suppressive capacity of naturally occurring $\mathrm{CD} 4+\mathrm{CD} 25+$ regulatory $\mathrm{T}$ cells in mice in vitro. J Pharmacol Exp Ther (2010) 335(3):553-61. doi: 10.1124/ jpet.110.169961

272. Fujii $T$, Watanabe $Y$, Inoue $T$, Kawashima K. Upregulation of mRNA encoding the M5 muscarinic acetylcholine receptor in human T- and Blymphocytes during immunological responses. Neurochem Res (2003) 28(34):423-9. doi: 10.1023/a:1022840416292

273. Fujino H, Uehara T, Murayama T, Okuma Y, Ariga H, Nomura $Y$. Extracellular signal regulated protein kinase and c-jun $\mathrm{N}$-terminal kinase are involved in ml muscarinic receptor-enhanced interleukin-2 production pathway in Jurkat cells. Biol Pharm Bull (2000) 23(10):1198-205. doi: $10.1248 / \mathrm{bpb} .23 .1198$ 
274. Asthana S, Greig NH, Holloway HW, Raffaele KC, Berardi A, Schapiro MB, et al. Clinical pharmacokinetics of arecoline in subjects with Alzheimer's disease. Clin Pharmacol Ther (1996) 60(3):276-82. doi: 10.1016/S0009-9236 (96) $90054-5$

275. Wen XM, Zhang YL, Liu XM, Guo SX, Wang H. Immune responses in mice to arecoline mediated by lymphocyte muscarinic acetylcholine receptor. Cell Biol Int (2006) 30(12):1048-53. doi: 10.1016/j.cellbi.2006.09.015

276. Darby M, Schnoeller C, Vira A, Culley FJ, Bobat S, Logan E, et al. The M3 muscarinic receptor is required for optimal adaptive immunity to helminth and bacterial infection. PloS Pathog (2015) 11(1):e1004636. doi: 10.1371/ journal.ppat.1004636

277. Skok MV, Grailhe R, Agenes F, Changeux JP. The role of nicotinic receptors in B-lymphocyte development and activation. Life Sci (2007) 80(2425):2334-6. doi: 10.1016/j.lfs.2007.02.005

278. Skok M, Grailhe R, Agenes F, Changeux JP. The role of nicotinic acetylcholine receptors in lymphocyte development. J Neuroimmunol (2006) 171(1-2):86-98. doi: 10.1016/j.jneuroim.2005.09.011

279. Skok M, Grailhe R, Changeux JP. Nicotinic receptors regulate B lymphocyte activation and immune response. Eur J Pharmacol (2005) 517(3):246-51. doi: 10.1016/j.ejphar.2005.05.011

280. Koval L, Kalashnyk O, Lykhmus O, Skok M. alpha7 nicotinic acetylcholine receptors are involved in suppression of the antibody immune response. J Neuroimmunol (2018) 318:8-14. doi: 10.1016/j.jneuroim.2018.01.012

281. Koval LM, Yu Lykhmus O, Omelchenko DM, Komisarenko SV, Skok MV. The role of alpha7 nicotinic acetylcholine receptors in B lymphocyte activation. Ukr Biokhim Zh (1999) (2009) 81(4):5-11.

282. Fujii YX, Tashiro A, Arimoto K, Fujigaya H, Moriwaki Y, Misawa H, et al. Diminished antigen-specific IgG1 and interleukin-6 production and acetylcholinesterase expression in combined M1 and M5 muscarinic acetylcholine receptor knockout mice. J Neuroimmunol (2007) 188(12):80-5. doi: 10.1016/j.jneuroim.2007.05.017

283. Hainke S, Wildmann J, Del Rey A. Deletion of muscarinic type 1 acetylcholine receptors alters splenic lymphocyte functions and splenic noradrenaline concentration. Int Immunopharmacol (2015) 29(1):135-42. doi: 10.1016/j.intimp.2015.05.010

284. Fujii T, Kawashima K. Calcium signaling and c-Fos gene expression via M3 muscarinic acetylcholine receptors in human T- and B-cells. Jpn J Pharmacol (2000) 84(2):124-32. doi: 10.1254/jjp.84.124

285. Nagaraju K, Cox A, Casciola-Rosen L, Rosen A. Novel fragments of the Sjogren's syndrome autoantigens alpha-fodrin and type 3 muscarinic acetylcholine receptor generated during cytotoxic lymphocyte granuleinduced cell death. Arthritis Rheum (2001) 44(10):2376-86. doi: 10.1002/ 1529-0131(200110)44:10<2376::AID-ART402>3.0.CO;2-E

286. Hogg N. Nicotine has suppressive effects on dendritic cell function. Immunology (2003) 109(3):329-30. doi: 10.1046/j.1365-2567.2003.01685.x

287. Liu D, Li T, Luo H, Zuo X, Liu S, Wu S. The effect of the cholinergic antiinflammatory pathway on collagen-induced arthritis involves the modulation of dendritic cell differentiation. Arthritis Res Ther (2018) 20 (1):263. doi: 10.1186/s13075-018-1759-9

288. Mashimo M, Takeshima S, Okuyama H, Matsurida A, Murase M, Ono S, et al. $\alpha 7 \mathrm{nAChRs}$ expressed on antigen presenting cells are insensitive to the conventional antagonists $\alpha$-bungarotoxin and methyllycaconitine. Int Immunopharmacol (2020) 81:106276. doi: 10.1016/j.intimp.2020.106276

289. Gori S, Vermeulen M, Remes-Lenicov F, Jancic C, Scordo W, Ceballos A, et al. Acetylcholine polarizes dendritic cells toward a Th2-promoting profile. Allergy (2017) 72(2):221-31. doi: 10.1111/all.12926

290. Nouri-Shirazi M, Kahlden C, Nishino P, Guinet E. Nicotine exposure alters the mRNA expression of Notch ligands in dendritic cells and their response to Th1-/Th2-promoting stimuli. Scand J Immunol (2015) 81(2):110-20. doi: $10.1111 /$ sji. 12254

291. Gao FG, Wan da F, Gu JR. Ex vivo nicotine stimulation augments the efficacy of therapeutic bone marrow-derived dendritic cell vaccination. Clin Cancer Res (2007) 13(12):3706-12. doi: 10.1158/1078-0432.CCR-07-0028

292. Mikulski Z, Hartmann P, Jositsch G, Zaslona Z, Lips KS, Pfeil U, et al. Nicotinic receptors on rat alveolar macrophages dampen ATP-induced increase in cytosolic calcium concentration. Respir Res (2010) 11:133. doi: 10.1186/1465-9921-11-133
293. Wang H, Yu M, Ochani M, Amella CA, Tanovic M, Susarla S, et al. Nicotinic acetylcholine receptor alpha7 subunit is an essential regulator of inflammation. Nature (2003) 421(6921):384-8. doi: 10.1038/nature01339

294. Tarnawski L, Reardon C, Caravaca AS, Rosas-Ballina M, Tusche MW, Drake AR, et al. Adenylyl Cyclase 6 Mediates Inhibition of TNF in the Inflammatory Reflex. Front Immunol (2018) 9:2648. doi: 10.3389/ fimmu.2018.02648

295. Borovikova LV, Ivanova S, Zhang M, Yang H, Botchkina GI, Watkins LR, et al. Vagus nerve stimulation attenuates the systemic inflammatory response to endotoxin. Nature (6785) 2000) 405:458-62. doi: 10.1038/35013070

296. de Jonge WJ, van der Zanden EP, The FO, Bijlsma MF, van Westerloo DJ, Bennink RJ, et al. Stimulation of the vagus nerve attenuates macrophage activation by activating the Jak2-STAT3 signaling pathway. Nat Immunol (2005) 6(8):844-51. doi: 10.1038/ni1229

297. Yang YH, Li DL, Bi XY, Sun L, Yu XJ, Fang HL, et al. Acetylcholine Inhibits LPS-Induced MMP-9 Production and Cell Migration via the alpha7 nAChRJAK2/STAT3 Pathway in RAW264.7 Cells. Cell Physiol Biochem (2015) 36 (5):2025-38. doi: 10.1159/000430170

298. Maldifassi MC, Atienza G, Arnalich F, Lopez-Collazo E, Cedillo JL, MartinSanchez C, et al. A new IRAK-M-mediated mechanism implicated in the anti-inflammatory effect of nicotine via alpha7 nicotinic receptors in human macrophages. PloS One (2014) 9(9):e108397. doi: 10.1371/journal. pone. 0108397

299. Nemethova A, Michel K, Gomez-Pinilla PJ, Boeckxstaens GE, Schemann M. Nicotine attenuates activation of tissue resident macrophages in the mouse stomach through the beta2 nicotinic acetylcholine receptor. PloS One (2013) 8(11):e79264. doi: 10.1371/journal.pone.0079264

300. Cailotto C, Gomez-Pinilla PJ, Costes LM, van der Vliet J, Di Giovangiulio M, Nemethova A, et al. Neuro-anatomical evidence indicating indirect modulation of macrophages by vagal efferents in the intestine but not in the spleen. PloS One (2014) 9(1):e87785. doi: 10.1371/journal.pone.0087785

301. Moussa AT, Rabung A, Reichrath S, Wagenpfeil S, Dinh T, Krasteva-Christ $\mathrm{G}$, et al. Modulation of macrophage phagocytosis in vitro-A role for cholinergic stimulation? Ann Anat (2017) 214:31-5. doi: 10.1016/ j.aanat.2017.07.007

302. de la Torre E, Genaro AM, Ribeiro ML, Pagotto R, Pignataro OP, Sales ME. Proliferative actions of muscarinic receptors expressed in macrophages derived from normal and tumor bearing mice. Biochim Biophys Acta (2008) 1782(2):82-9. doi: 10.1016/j.bbadis.2007.11.005

303. Mishra NC, Rir-sima-ah J, Boyd RT, Singh SP, Gundavarapu S, Langley RJ, et al. Nicotine inhibits Fc epsilon RI-induced cysteinyl leukotrienes and cytokine production without affecting mast cell degranulation through alpha 7/alpha 9/alpha 10-nicotinic receptors. J Immunol (2010) 185(1):588-96. doi: $10.4049 /$ jimmunol.0902227

304. Fantozzi R, Masini E, Blandina P, Mannaioni PF, Bani-Sacchi T. Release of histamine from rat mast cells by acetylcholine. Nature (1978) 273 (5662):473-4. doi: 10.1038/273473a0

305. Kaliner M, Orange RP, Austen KF. Immunological release of histamine and slow reacting substance of anaphylaxis from human lung. J Exp Med (1972) 136(3):556-67. doi: 10.1084/jem.136.3.556

306. Sudheer PS, Hall JE, Donev R, Read G, Rowbottom A, Williams PE. Nicotinic acetylcholine receptors on basophils and mast cells. Anaesthesia (2006) 61 (12):1170-4. doi: 10.1111/j.1365-2044.2006.04870.x

307. Wallon C, Persborn M, Jonsson M, Wang A, Phan V, Lampinen M, et al. Eosinophils express muscarinic receptors and corticotropin-releasing factor to disrupt the mucosal barrier in ulcerative colitis. Gastroenterology (2011) 140(5):1597-607. doi: 10.1053/j.gastro.2011.01.042

308. Reinheimer T, Baumgartner D, Hohle KD, Racke K, Wessler I. Acetylcholine via muscarinic receptors inhibits histamine release from human isolated bronchi. Am J Respir Crit Care Med (1997) 156(2 Pt 1):389-95. doi: 10.1164/ ajrccm.156.2.96-12079

309. Chahdi A, Daeffler L, Bueb JL, Gies JP, Landry Y. The M2 muscarinic receptor antagonist methoctramine activates mast cells via pertussis toxinsensitive G proteins. Naunyn Schmiedebergs Arch Pharmacol (1998) 357 (4):357-62. doi: 10.1007/PL00005179

310. Windmiller DA, Backer JM. Distinct phosphoinositide 3-kinases mediate mast cell degranulation in response to G-protein-coupled versus FcepsilonRI 
receptors. J Biol Chem (2003) 278(14):11874-8. doi: 10.1074/ jbc.M211787200

311. Nishida K, Yamasaki S, Ito Y, Kabu K, Hattori K, Tezuka T, et al. Fc\{epsilon\} RI-mediated mast cell degranulation requires calcium-independent microtubule-dependent translocation of granules to the plasma membrane. J Cell Biol (2005) 170(1):115-26. doi: 10.1083/jcb.200501111

312. Djouder N, Aneiros E, Cavalie A, Aktories K. Effects of large clostridial cytotoxins on activation of RBL $2 \mathrm{H} 3-\mathrm{hm} 1$ mast cells indicate common and different roles of Rac in FcepsilonRI and M1-receptor signaling. J Pharmacol Exp Ther (2003) 304(3):1243-50. doi: 10.1124/jpet.102.045351

313. Safronova VG, Vulfius CA, Shelukhina IV, Mal'tseva VN, Berezhnov AV, Fedotova EI, et al. Nicotinic receptor involvement in regulation of functions of mouse neutrophils from inflammatory site. Immunobiology (2016) 221 (7):761-72. doi: 10.1016/j.imbio.2016.01.016

314. Huston JM, Rosas-Ballina M, Xue X, Dowling O, Ochani K, Ochani M, et al. Cholinergic neural signals to the spleen down-regulate leukocyte trafficking via CD1 1b. J Immunol (2009) 183(1):552-9. doi: 10.4049/jimmunol.0802684

315. Dutta G, Ghosh T. Effects of stimulation of muscarinic acetylcholine receptors in medial septum on some immune responses in rats. Neurosci Lett (2016) 619:155-61. doi: 10.1016/j.neulet.2016.03.023

316. Profita M, Bonanno A, Siena L, Ferraro M, Montalbano AM, Pompeo F, et al. Acetylcholine mediates the release of IL-8 in human bronchial epithelial cells by a NFkB/ERK-dependent mechanism. Eur J Pharmacol (2008) 582(13):145-53. doi: 10.1016/j.ejphar.2007.12.029

317. Carmona-Rivera C, Purmalek MM, Moore E, Waldman M, Walter PJ, Garraffo HM, et al. A role for muscarinic receptors in neutrophil extracellular trap formation and levamisole-induced autoimmunity. JCI Insight (2017) 2(3):e89780. doi: 10.1172/jci.insight.89780

318. Kistemaker LE, van Os RP, Dethmers-Ausema A, Bos IS, Hylkema MN, van den Berge $\mathrm{M}$, et al. Muscarinic M3 receptors on structural cells regulate cigarette smoke-induced neutrophilic airway inflammation in mice. Am J Physiol Lung Cell Mol Physiol (2015) 308(1):L96-103. doi: 10.1152/ ajplung.00259.2014

319. Profita M, Bonanno A, Montalbano AM, Albano GD, Riccobono L, Siena L, et al. beta(2) long-acting and anticholinergic drugs control TGF-betalmediated neutrophilic inflammation in COPD. Biochim Biophys Acta (2012) 1822(7):1079-89. doi: 10.1016/j.bbadis.2012.03.002

320. Nie Z, Scott GD, Weis PD, Itakura A, Fryer AD, Jacoby DB. Role of TNFalpha in virus-induced airway hyperresponsiveness and neuronal $\mathrm{M}(2)$ muscarinic receptor dysfunction. Br J Pharmacol (2011) 164(2b):444-52. doi: 10.1111/j.1476-5381.2011.01393.x

321. Paul S, Lal G. The Molecular Mechanism of Natural Killer Cells Function and Its Importance in Cancer Immunotherapy. Front Immunol (2017) 8:1124. doi: $10.3389 /$ fimmu.2017.01124

322. Jiang W, Li D, Han R, Zhang C, Jin WN, Wood K, et al. Acetylcholineproducing NK cells attenuate CNS inflammation via modulation of infiltrating monocytes/macrophages. Proc Natl Acad Sci USA (2017) 114: E-6202-E11. doi: 10.1073/pnas.1705491114

323. Hao J, Shi FD, Abdelwahab M, Shi SX, Simard A, Whiteaker P, et al. Nicotinic receptor beta2 determines NK cell-dependent metastasis in a murine model of metastatic lung cancer. PloS One (2013) 8(2):e57495. doi: 10.1371/journal.pone.0057495

324. Marshall-Gradisnik S, Huth T, Chacko A, Johnston S, Smith P, Staines D. Natural killer cells and single nucleotide polymorphisms of specific ion channels and receptor genes in myalgic encephalomyelitis/chronic fatigue syndrome. Appl Clin Genet (2016) 9:39-47. doi: 10.2147/TACG.S99405

325. Jiang JL, Qiu YH, Peng YP. [Effect of acetylcholine on the cytotoxicity of natural killer cells]. Zhongguo Ying Yong Sheng Li Xue Za Zhi (2005) 21 (3):330-3.

326. Verbout NG, Jacoby DB, Gleich GJ, Fryer AD. Atropine-enhanced, antigen challenge-induced airway hyperreactivity in guinea pigs is mediated by eosinophils and nerve growth factor. Am J Physiol Lung Cell Mol Physiol (2009) 297(2):L228-37. doi: 10.1152/ajplung.90540.2008

327. Browning KN, Travagli RA. Central nervous system control of gastrointestinal motility and secretion and modulation of gastrointestinal functions. Compr Physiol (2014) 4(4):1339-68. doi: 10.1002/cphy.c130055

328. Tracey KJ. Reflex control of immunity. Nat Rev Immunol (2009) 9(6):41828. doi: $10.1038 /$ nri2566
329. Stein KS, McFarlane IC, Goldberg N, Ginzler EM. Heart rate variability in patients with systemic lupus erythematosus. Lupus (1996) 5(1):44-8. doi: $10.1177 / 096120339600500109$

330. Pontet J, Contreras P, Curbelo A, Medina J, Noveri S, Bentancourt S, et al. Heart rate variability as early marker of multiple organ dysfunction syndrome in septic patients. J Crit Care (2003) 18(3):156-63. doi: 10.1016/ j.jcrc.2003.08.005

331. Reisner BS, Straley SC. Yersinia pestis YopM: thrombin binding and overexpression. Infect Immun (1992) 60(12):5242-52. doi: 10.1128/ IAI.60.12.5242-5252.1992

332. Lindgren S, Stewenius J, Sjölund K, Lilja B, Sundkvist G. Autonomic vagal nerve dysfunction in patients with ulcerative colitis. Scand J Gastroenterol (1993) 28(7):638-42. doi: 10.3109/00365529309096103

333. Zi S, Li J, Liu L, Liu F. Cholinergic anti-inflammatory pathway and its role in treatment of sepsis. Zhong Nan Da Xue Xue Bao Yi Xue Ban (2020) 45(1):6873. doi: $10.11817 /$ j.issn.1672-7347.2020.180651

334. Huston JM. The vagus nerve and the inflammatory reflex: wandering on a new treatment paradigm for systemic inflammation and sepsis. Surg Infect (Larchmt) (2012) 13(4):187-93. doi: 10.1089/sur.2012.126

335. Koopman FA, Chavan SS, Miljko S, Grazio S, Sokolovic S, Schuurman PR, et al. Vagus nerve stimulation inhibits cytokine production and attenuates disease severity in rheumatoid arthritis. Proc Natl Acad Sci USA (2016) 113 (29):8284-9. doi: 10.1073/pnas.1605635113

336. Onuora S. Rheumatoid arthritis: Vagus nerve stimulation reduces RA severity in patients. Nat Rev Rheumatol (2016) 12(9):500. doi: 10.1038/ nrrheum.2016.126

337. Bonaz B, Sinniger V, Pellissier S. Targeting the cholinergic antiinflammatory pathway with vagus nerve stimulation in patients with Covid-19? Bioelectron Med (2020) 6:15. doi: 10.1186/s42234-020-00051-7

338. Porzionato A, Emmi A, Barbon S, Boscolo-Berto R, Stecco C, Stocco E, et al. Sympathetic activation: a potential link between comorbidities and COVID19. FEBS J (2020) 287(17):3681-8. doi: 10.1111/febs.15481

339. Rosas-Ballina M. al. e. Splenic nerve is required for cholinergic antiinflammatory pathway control of TNF in endotoxemia. PNAS (2008) 105(31):11008-13. doi: 10.1073/pnas.0803237105

340. Reardon C, Duncan GS, Brustle A, Brenner D, Tusche MW, Olofsson PS, et al. Lymphocyte-derived $\mathrm{ACh}$ regulates local innate but not adaptive immunity. Proc Natl Acad Sci USA (2013) 110(4):1410-5. doi: 10.1073/ pnas. 1221655110

341. Benowitz NL, Burbank AD. Cardiovascular toxicity of nicotine: Implications for electronic cigarette use. Trends Cardiovasc Med (2016) 26(6):515-23. doi: $10.1016 / j . t c m .2016 .03 .001$

342. Shao XM, López-Valdés HE, Liang J, Feldman JL. Inhaled nicotine equivalent to cigarette smoking disrupts systemic and uterine hemodynamics and induces cardiac arrhythmia in pregnant rats. Sci Rep (2017) 7(1):16974. doi: 10.1038/s41598-017-17301-5

343. Haussmann HJ, Fariss MW. Comprehensive review of epidemiological and animal studies on the potential carcinogenic effects of nicotine per se. Crit Rev Toxicol (2016) 46(8):701-34. doi: 10.1080/10408444. 2016.1182116

344. Bagdas D, AlSharari SD, Freitas K, Tracy M, Damaj MI. The role of alpha5 nicotinic acetylcholine receptors in mouse models of chronic inflammatory and neuropathic pain. Biochem Pharmacol (2015) 97(4):590-600. doi: 10.1016/j.bcp.2015.04.013

345. Kitagawa H, Takenouchi T, Azuma R, Wesnes KA, Kramer WG, Clody DE, et al. Safety, pharmacokinetics, and effects on cognitive function of multiple doses of GTS-21 in healthy, male volunteers. Neuropsychopharmacology (2003) 28(3):542-51. doi: 10.1038/sj.npp.1300028

346. Rosas-Ballina M, Goldstein RS, Gallowitsch-Puerta M, Yang L, Valdés-Ferrer SI, Patel NB, et al. The selective alpha7 agonist GTS-21 attenuates cytokine production in human whole blood and human monocytes activated by ligands for TLR2, TLR3, TLR4, TLR9, and RAGE. Mol Med (2009) 15(78):195-202. doi: 10.2119/molmed.2009.00039

347. Yue Y, Liu R, Cheng W, Hu Y, Li J, Pan X, et al. GTS-21 attenuates lipopolysaccharide-induced inflammatory cytokine production in vitro by modulating the Akt and NF- $\mathrm{KB}$ signaling pathway through the $\alpha 7$ nicotinic acetylcholine receptor. Int Immunopharmacol (2015) 29(2):504-12. doi: 10.1016/j.intimp.2015.10.005 
348. Wu XJ, Yan XT, Yang XM, Zhang Y, Wang HY, Luo H, et al. GTS-21 ameliorates polymicrobial sepsis-induced hepatic injury by modulating autophagy through alpha7nAchRs in mice. Cytokine (2020) 128:155019. doi: 10.1016/j.cyto.2020.155019

349. Kox M, Pompe JC, Gordinou de Gouberville MC, van der Hoeven JG, Hoedemaekers CW, Pickkers P. Effects of the alpha7 nicotinic acetylcholine receptor agonist GTS-21 on the innate immune response in humans. Shock (Augusta Ga) (2011) 36(1):5-11. doi: 10.1097/SHK.0b013e3182168d56

350. Ulloa L. The anti-inflammatory potential of selective cholinergic agonists. Shock (2011) 36(1):97-8. doi: 10.1097/SHK.0b013e31821820d2

351. Douaoui S, Djidjik R, Boubakeur M, Ghernaout M, Touil-Boukoffa C, Oumouna $\mathrm{M}$, et al. GTS-21, an $\alpha 7 \mathrm{nAChR}$ agonist, suppressed the production of key inflammatory mediators by PBMCs that are elevated in COPD patients and associated with impaired lung function. Immunobiology (2020) 225(3):151950. doi: 10.1016/j.imbio.2020.151950

352. Wu S, Zhao H, Luo H, Xiao X, Zhang H, Li T, et al. GTS-21, an $\alpha 7$-nicotinic acetylcholine receptor agonist, modulates Th1 differentiation in CD4. Exp Ther Med (2014) 8(2):557-62. doi: 10.3892/etm.2014.1754

353. Shin SS, Dixon CE. Alterations in Cholinergic Pathways and Therapeutic Strategies Targeting Cholinergic System after Traumatic Brain Injury. J Neurotrauma (2015) 32(19):1429-40. doi: 10.1089/neu.2014.3445

354. Yang T, Xiao T, Sun Q, Wang K. The current agonists and positive allosteric modulators of. Acta Pharm Sin B (2017) 7(6):611-22. doi: 10.1016/ j.apsb.2017.09.001

355. van Westerloo DJ, Giebelen IA, Florquin S, Bruno MJ, Larosa GJ, Ulloa L, et al. The vagus nerve and nicotinic receptors modulate experimental pancreatitis severity in mice. Gastroenterology (2006) 130(6):1822-30. doi: 10.1053/j.gastro.2006.02.022

356. Gault LM, Ritchie CW, Robieson WZ, Pritchett Y, Othman AA, Lenz RA. A phase 2 randomized, controlled trial of the alpha7 agonist ABT-126 in mildto-moderate Alzheimer's dementia. Alzheimers Dement (N Y) (2015) 1 (1):81-90. doi: 10.1016/j.trci.2015.06.001

357. Haig GM, Wang D, Zhao J, Othman AA, Bain EE. Efficacy and Safety of the alpha7-Nicotinic Acetylcholine Receptor Agonist ABT-126 in the Treatment of Cognitive Impairment Associated With Schizophrenia: Results From a Phase 2b Randomized Controlled Study in Smokers. J Clin Psychiatry (2018) 79(3):16m11162. doi: 10.4088/JCP.16m11162

358. Bernik TR, Friedman SG, Ochani M, DiRaimo R, Ulloa L, Yang H, et al. Pharmacological stimulation of the cholinergic antiinflammatory pathway. J Exp Med (2002) 195(6):781-8. doi: 10.1084/jem.20011714

359. Bianchi M, Ulrich P, Bloom O, Meistrell M, Zimmerman GA, Schmidtmayerova $\mathrm{H}$, et al. An inhibitor of macrophage arginine transport and nitric oxide production (CNI-1493) prevents acute inflammation and endotoxin lethality. Mol Med (1995) 1(3):254-66. doi: 10.1007/BF03401550

360. Borovikova LV, Ivanova S, Nardi D, Zhang M, Yang H, Ombrellino M, et al. Role of vagus nerve signaling in CNI-1493-mediated suppression of acute inflammation. Auton Neurosci (2000) 85(1-3):141-7. doi: 10.1016/S15660702(00)00233-2

361. Bach JP, Mengel D, Wahle T, Kautz A, Balzer-Geldsetzer M, Al-Abed Y, et al. The role of CNI-1493 in the function of primary microglia with respect to amyloid- $\beta$. J Alzheimers Dis (2011) 26(1):69-80. doi: 10.3233/JAD-2011110179

362. Björk L, Tracey KJ, Ulrich P, Bianchi M, Cohen PS, Akerlund K, et al. Targeted suppression of cytokine production in monocytes but not in $\mathrm{T}$ lymphocytes by a tetravalent guanylhydrazone (CNI-1493). J Infect Dis (1997) 176(5):1303-12. doi: 10.1086/514126

363. Cohen PS, Nakshatri H, Dennis J, Caragine T, Bianchi M, Cerami A, et al. CNI-1493 inhibits monocyte/macrophage tumor necrosis factor by suppression of translation efficiency. Proc Natl Acad Sci USA (1996) 93 (9):3967-71. doi: 10.1073/pnas.93.9.3967

364. Abdalla H, Forslund T, Schön T, Stendahl O, Sundqvist T. Effects of CNI1493 on human granulocyte functions. Immunobiology (2006) 211(3):191-7. doi: 10.1016/j.imbio.2005.09.006

365. Zinser E, Turza N, Steinkasserer A. CNI-1493 mediated suppression of dendritic cell activation in vitro and in vivo. Immunobiology (2004) 209(12):89-97. doi: 10.1016/j.imbio.2004.04.004

366. Hommes D, van den Blink B, Plasse T, Bartelsman J, Xu C, Macpherson B, et al. Inhibition of stress-activated MAP kinases induces clinical improvement in moderate to severe Crohn's disease. Gastroenterology (2002) 122(1):7-14. doi: 10.1053/gast.2002.30770

367. van Westerloo DJ, Rauws EA, Hommes D, de Vos AF, van der Poll T, Powers $\mathrm{BL}$, et al. Pre-ERCP infusion of semapimod, a mitogen-activated protein kinases inhibitor, lowers post-ERCP hyperamylasemia but not pancreatitis incidence. Gastrointest Endosc (2008) 68(2):246-54. doi: 10.1016/ j.gie.2008.01.034

368. Tsifetaki N, Kitsos G, Paschides CA, Alamanos Y, Eftaxias V, Voulgari PV, et al. Oral pilocarpine for the treatment of ocular symptoms in patients with Sjogren's syndrome: a randomised 12 week controlled study. Ann Rheumatic Dis (2003) 62(12):1204-7. doi: 10.1136/ard.2002.003889

369. Habek M. Immune and autonomic nervous system interactions in multiple sclerosis: clinical implications. Clin Auton Res (2019) 29(3):267-75. doi: 10.1007/s10286-019-00605-z

370. Nile C, Falleni M, Cirasola D, Alghamdi A, Anderson OF, Delaney C, et al. Repurposing Pilocarpine Hydrochloride for Treatment of Candida albicans Infections. mSphere (2019) 4(1):e00689-18. doi: 10.1128/mSphere.00689-18

371. Minagi HO, Ikai K, Araie T, Sakai M, Sakai T. Benefits of long-term pilocarpine due to increased muscarinic acetylcholine receptor 3 in salivary glands. Biochem Biophys Res Commun (2018) 503(2):1098-102. doi: 10.1016/j.bbrc.2018.06.125

372. Marchi N, Oby E, Batra A, Uva L, De Curtis M, Hernandez N, et al. In vivo and in vitro effects of pilocarpine: relevance to ictogenesis. Epilepsia (2007) 48(10):1934-46. doi: 10.1111/j.1528-1167.2007.01185.x

373. Scorza FA, Arida RM, Naffah-Mazzacoratti M, Scerni DA, Calderazzo L, Cavalheiro EA. The pilocarpine model of epilepsy: what have we learned? Acad Bras Cienc (2009) 81(3):345-65. doi: 10.1590/s000137652009000300003

374. Tomiita M, Takei S, Kuwada N, Nonaka Y, Saito K, Shimojo N, et al. Efficacy and safety of orally administered pilocarpine hydrochloride for patients with juvenile-onset Sjögren's syndrome. Mod Rheumatol (2010) 20(5):486-90. doi: 10.1007/s10165-010-0313-7

375. Hampel H, Mesulam MM, Cuello AC, Farlow MR, Giacobini E, Grossberg GT, et al. The cholinergic system in the pathophysiology and treatment of Alzheimer's disease. Brain (2018) 141(7):1917-33. doi: 10.1093/brain/awy132

376. Saldanha C. Human Erythrocyte Acetylcholinesterase in Health and Disease. Molecules (2017) 22(9):1499. doi: 10.3390/molecules22091499

377. Freitas Leal JK, Adjobo-Hermans MJW, Brock R, Bosman G. Acetylcholinesterase provides new insights into red blood cell ageing in vivo and in vitro. Blood Transfus (2017) 15(3):232-8. doi: 10.2450/ 2017.0370-16

378. Das UN. Acetylcholinesterase and butyrylcholinesterase as possible markers of low-grade systemic inflammation. Med Sci Monit (2007) 13(12):RA214-21.

379. Pohanka M. Inhibitors of acetylcholinesterase and butyrylcholinesterase meet immunity. Int J Mol Sci (2014) 15(6):9809-25. doi: 10.3390/ ijms15069809

380. Song P, Spindel ER. Basic and clinical aspects of non-neuronal acetylcholine: expression of non-neuronal acetylcholine in lung cancer provides a new target for cancer therapy. J Pharmacol Sci (2008) 106(2):180-5. doi: 10.1254/ jphs.fm0070091

381. Predescu DV, Cretoiu SM, Cretoiu D, Pavelescu LA, Suciu N, Radu BM, et al. G Protein-Coupled Receptors (GPCRs)-Mediated Calcium Signaling in Ovarian Cancer: Focus on GPCRs activated by Neurotransmitters and Inflammation-Associated Molecules. Int J Mol Sci (2019) 20(22):5568. doi: 10.3390/ijms20225568

382. Buels KS, Fryer AD. Muscarinic receptor antagonists: effects on pulmonary function. Handb Exp Pharmacol (2012) 208):317-41. doi: 10.1007/978-3642-23274-9_14

383. Tsuji H, Okamoto K, Matsuzaka Y, Iizuka H, Tamiya G, Inoko H. SLURP-2, a novel member of the human Ly-6 superfamily that is up-regulated in psoriasis vulgaris. Genomics (2003) 81(1):26-33. doi: 10.1016/s0888-7543 (02)00025-3

384. Baroni A, Buommino E, Ruocco E, Petrazzuolo M, De Filippis A, Satriano RA, et al. Captopril modulates acetylcholinesterase in human keratinocytes. Arch Dermatol Res (2011) 303(7):491-7. doi: 10.1007/s00403-011-1124-1

385. Yang WL, Frucht H. Cholinergic receptor up-regulates COX-2 expression and prostaglandin $\mathrm{E}(2)$ production in colon cancer cells. Carcinogenesis (2000) 21(10):1789-93. doi: 10.1093/carcin/21.10.1789 
386. Samuel I, Zaheer S, Fisher RA, Zaheer A. Cholinergic receptor induction and JNK activation in acute pancreatitis. Am J Surg (2003) 186(5):569-74. doi: 10.1016/j.amjsurg.2003.07.016

387. Bacher I, Wu B, Shytle DR, George TP. Mecamylamine - a nicotinic acetylcholine receptor antagonist with potential for the treatment of neuropsychiatric disorders. Expert Opin Pharmacother (2009) 10 (16):2709-21. doi: 10.1517/14656560903329102

388. Bai X, Stitzel JA, Bai A, Zambrano CA, Phillips M, Marrack P, et al. Nicotine Impairs Macrophage Control of Mycobacterium tuberculosis. Am J Respir Cell Mol Biol (2017) 57(3):324-33. doi: 10.1165/rcmb.2016-0270OC

389. Brady WJ, Swart G, DeBehnke DJ, Ma OJ, Aufderheide TP. The efficacy of atropine in the treatment of hemodynamically unstable bradycardia and atrioventricular block: prehospital and emergency department considerations. Resuscitation (1999) 41(1):47-55. doi: 10.1016/s0300-9572 (99)00032-5

390. Qiu YH, Peng YP, Jiang JL, Wang JJ. Effect of acetylcholine on in vitro IL-2 production and NK cell cytotoxicity of rats. Lymphology (2004) 37(1):31-8.

391. Freier S, Eran M, Faber J. Effect of cholecystokinin and of its antagonist, of atropine, and of food on the release of immunoglobulin $\mathrm{A}$ and immunoglobulin G specific antibodies in the rat intestine. Gastroenterology (1987) 93(6):1242-6. doi: 10.1016/0016-5085(87)90251-4

392. Juneja M, Baidoo L, Schwartz MB, Barrie A, Regueiro M, Dunn M, et al. Geriatric inflammatory bowel disease: phenotypic presentation, treatment patterns, nutritional status, outcomes, and comorbidity. Dig Dis Sci (2012) 57 (9):2408-15. doi: 10.1007/s10620-012-2083-x

393. Gold R, Hohlfeld R, Toyka KV. Progress in the treatment of myasthenia gravis. Ther Adv Neurol Disord (2008) 1(2):36-51. doi: 10.1177/ 1756285608093888

394. Galvis V, Tello A, Parra MM, Merayo-Lloves J, Larrea J, Julian Rodriguez C, et al. Topical Atropine in the Control of Myopia. Med Hypothesis Discovery Innov Ophthalmol (2016) 5(3):78-88.

395. Page JG, Dirnberger GM. Treatment of the irritable bowel syndrome with Bentyl (dicyclomine hydrochloride). J Clin Gastroenterol (1981) 3(2):153-6. doi: 10.1097/00004836-198106000-00009

396. Nee J, Zakari M, Lembo AJ. Novel Therapies in IBS-D Treatment. Curr Treat Options Gastroenterol (2015) 13(4):432-40. doi: 10.1007/s11938-015-0068-5

397. Ali A, Jadhav A, Jangid P, Patil R, Shelar A, Karuppayil SM. The human muscarinic acetylcholine receptor antagonist, Dicyclomine targets signal transduction genes and inhibits the virulence factors in the human pathogen, Candida albicans. J Antibiot (Tokyo) (2018) 71(4):456-66. doi: 10.1038/s41429-017-0013-z

398. Karak P, Kumar KA, Mazumdar K, Mookerjee M, Dastidar SG. Antibacterial potential of an antispasmodic drug dicyclomine hydrochloride. Indian J Med Res (2003) 118:192-6.
399. Talebi M, Minai-Tehrani D, Fazilati M, Minai-Tehrani A. Inhibitory action of dicyclomine on lipase activity, kinetics and molecular study. Int J Biol Macromol (2018) 107(Pt B):2422-8. doi: 10.1016/j.ijbiomac.2017.10.123

400. Matera MG, Rinaldi B, Berardo C, Rinaldi M, Cazzola M. A review of the pharmacokinetics of M3 muscarinic receptor antagonists used for the treatment of asthma. Expert Opin Drug Metab Toxicol (2020) 16(2):143-8. doi: 10.1080/17425255.2020.1716730

401. Ohta S, Oda N, Yokoe T, Tanaka A, Yamamoto Y, Watanabe Y, et al. Effect of tiotropium bromide on airway inflammation and remodelling in a mouse model of asthma. Clin Exp Allergy (2010) 40(8):1266-75. doi: 10.1111/j.13652222.2010.03478.x

402. Buhling F, Lieder N, Kuhlmann UC, Waldburg N, Welte T. Tiotropium suppresses acetylcholine-induced release of chemotactic mediators in vitro. Respir Med (2007) 101(11):2386-94. doi: 10.1016/j.rmed.2007.06.009

403. Vacca G, Randerath WJ, Gillissen A. Inhibition of granulocyte migration by tiotropium bromide. Respir Res (2011) 12:24. doi: 10.1186/1465-9921-12-24

404. Sato E, Koyama S, Okubo Y, Kubo K, Sekiguchi M. Acetylcholine stimulates alveolar macrophages to release inflammatory cell chemotactic activity. Am J Physiol (1998) 274(6 Pt 1):L970-9. doi: 10.1152/ajplung.1998.274.6.L970

405. Dantzer R. Neuroimmune Interactions: From the Brain to the Immune System and Vice Versa. Physiol Rev (2018) 98(1):477-504. doi: 10.1152/ physrev.00039.2016

406. Reardon C, Murray K, Lomax AE. Neuroimmune Communication in Health and Disease. Physiol Rev (2018) 98(4):2287-316. doi: 10.1152/ physrev.00035.2017

407. Murray K, Barboza M, Rude KM, Brust-Mascher I, Reardon C. Functional circuitry of neuro-immune communication in the mesenteric lymph node and spleen. Brain Behav Immun (2019) 82:214-23. doi: 10.1016/ j.bbi.2019.08.188

408. Bradley SJ, Molloy C, Valuskova P, Dwomoh L, Scarpa M, Rossi M, et al. Biased M1-muscarinic-receptor-mutant mice inform the design of nextgeneration drugs. Nat Chem Biol (2020) 16(3):240-9. doi: 10.1038/s41589019-0453-9

Conflict of Interest: The authors declare that the research was conducted in the absence of any commercial or financial relationships that could be construed as a potential conflict of interest.

Copyright (c) 2021 Halder and Lal. This is an open-access article distributed under the terms of the Creative Commons Attribution License (CC BY). The use, distribution or reproduction in other forums is permitted, provided the original author(s) and the copyright owner(s) are credited and that the original publication in this journal is cited, in accordance with accepted academic practice. No use, distribution or reproduction is permitted which does not comply with these terms. 